233 Pouching operationの手技と成績 喷門側胃切除術

山形大学第 1 外科 ${ }^{17}$, 山形県立河北病院外科 ${ }^{2}$ 亀山仁一, 矢作祐一, 長谷川繁生, 石田一, 星川匡, 薄場 修, 豊野充, 鈴木 晃, 吉村信幸, 川村博司, 塚本 長”, 千葉昌和 ${ }^{2 \prime}$ QOLの面から有茎空腸襄を用いた新しい噴門側胃切 除術を考案し, 犬を用いた動物実験を経て, これまで 23例に臨床応用した。【手術手技】約 $40 \mathrm{~cm}$ の有茎空 腸を逆U字型に側側吻合し, 空腸囊を作製する。食道 空腸粪吻合, 空腸囊残胃吻合, 幽門筋切離, 空腸空腸 吻合を行って手術を終了する，逆流性食道炎の防止の ため口側先進部となる約 $1.5 \mathrm{~cm}$ の腸管の吻合は行わず に隔壁として残すこと, 吻合部位は空腸輬の右側, 前 壁とするなどが重要である。吻合部の止血は空腸裹を 完全に翻転し，直視下に確実に行っているので，その コッなどを供覧する。【術後成績】初期の症例で minor leakageが 1 例，吻合部出血が 2 例にみられたが， 手術手技の改善後みられなくなった。術後経過は良好 で, 早期より満足できる食事が可能であった。レ線学 的，内視鏡的に残胃や十二指腸の検索も容易であった. 【まとめ】本術式は残胃の容量, 逆流性食道炎, 残胃 の検索や内視鏡的治療, 十二指腸 - 胆道 - 莢の検索や 内視鏡的治療という面でメリットの大きい方法である.

(有荎二重空腸間置術)

大分医科大学第 2 外科

野口 剛、内田雄三、村上信一、久保宣博、 平岡善憲、平田孝浩

【緒言】従来、教室では噴切後の再建に有茎空腸間置 術を行ってきたが、最近、(1)貯留能の増加、(2)压上昇 に対する緩衝の役割、(3)逆流の防止、などを目的とし て有茎二重空腸間置法による再建を行い、良好な結果 を得ているのでその手術術式を紹介する。

【手術術式】(1)噴門側胃切除および食道空腸吻合 : 大 彎側と小彎側の遊離および食道の切離を終了し，胃を 2 分の 1 の部位で横切する。トライツ勒帯より 20 $30 \mathrm{~cm}$ の部位で空腸を横切し、遠位側空腸切離端を残存 食道下端と彎曲分解型自動吻合器を用いて吻合する ( $\rho$ 型)。(2)二重空腸雯の作成 : 間置空腸の長さが約 25 〜30 cmとなるように(二重空腸衰部分も含む)、挙上空

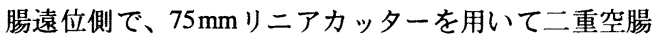
衰を作成する。このさい、リニアカッター挿入部分の 空腸を4〜 5cm犠牲にし、リニアカッターをかける部位 は腸間膜付着部位の対側となるよう注意する。(3)空腸 残胃吻合 (4)幽門形成術 : 迷走神経を温存できなかっ た場合はHeineke-Mikulicz法による幽門形成を追加する。 【成績】現在まで 5 例に本術式を行った。通常の空腸 間置術と比べて、食䬣摂取量は有意の差はないが、術 後造影で逆流を認めず、また眝留能も良好であった。
235 胃切除後の再建 pouch作成の手枝と成績 半田市立半田病院 外科 多米英介，川井覚，児玉葉子，武田秀夫，法水信治， 宮猗耕, 吉原基, 黒柳裕, 小島良宏, 久保田仁

【目的】我々は平成 3 年 7 月以後, 術後長期生存が 期待される胃癌症例にpouchを作成, 良好な結果を得 ているので手術手枝をビテオで供覧するとともに術後 行っている排出試験について報告する。【対象·手術 手枝】胃切除例 2 例（小弯全切除 3 例）, 全摘例16例 を対象とした。 $\mathrm{D}_{2}+$ (12)(13)胆摘, 全摘例では丸山らの術 式に準じて脾摘を行った。胃切除例では $20 〜 25 \mathrm{~cm}$ の空 腸を用いる。GIA80を使用, 肛門側にpouchを作成, 結 腸後経路で举上, 十二指腸之端側吻合する。最後に残 胃と空腸を吻合する。全摘例では 45〜 50cmの空腸を使 用, GIA80を 2 回使用, 肛門側に $15 \mathrm{~cm}$ の pouchを作成, 再建する。【考案およひ結語】排出試験では11例（21 例中）で良好な結果を得た。このうちには小弯側全切 除 2 例が含まれている。又pouchと残胃との間が長か った症例では残胃から排出されず再手術(残胃空腸吻 合)を行った。従って間置空腸をあまり長くしないて と。又, 残胃空腸吻合部が直角にならないような配慮 が必要と思われる。全摘例では間置した空腸の部分が 脾, 胃全摘した部位にゆったりと収まれば問題ないと 考えている。

\section{6 大腸間是による再再建術式}

千葉大学第一外科布村正夫、更科廣宾、斉藤典男 滝口伸浩、幸田圭史、小田健司、早田浩明、尾崎和義 菅谷芳樹、江沢英史、鈴木弘文、近藤英介、知久 媇 若月一雄、吉村光太郎、安富 淳、石川文彦 古川留魅子、中島伸之

胃癌手術後の食物眝留能を補う目的で、当科では管 腔が広く、それ自体が眝留能力を保持しうる大晹を最 近間置臟器に用いており手術の実際を提示する。1）胃 全摘術および噴門側胃要全摘術における回結晹間置術。 この術式は回盲弁に噴門機能を期待し、早期癌の場合 さらに幽門温存により食物の貯留排出を円滑にしよう とするものである。吻合操作はすへて器械吻合器を使 用しており、上行結腸・残胃または十二指腸吻合はdouble stapling methodで端端吻合、食道・回腸吻合は通 常 CDH を使用し端側吻合する。

2）幽門側胃严全摘術における横行結腸間置術。この術 式は胃切除後の容量の增大とともに逆流性食道炎の防 止も目的としている。横行結腸を順蜻動性に間置し、こ れも自動吻合器を使用して横行結腸・十二指腸吻合お よび残胃・横行結晹を吻合する。

術後の造影および内視鏡検査でも逆流のない良好な 代用胃としての運動が認められ、小腸 pouchに変わり うる優れた胃再建法と考えられる。 


\section{金沢医科大学一般消化器外科}

小坂健夫、高野靖、中野泰治、秋山高儀、

冨田冨士夫、斎藤人志、喜多一郎、高島茂樹

【目的】胃全摘術後の空腸pouch間置術は、食物の貯留 能を有し、しかも食物が十二指腸を経由する点に特徵 のある術式である。pouch作製にあたっての私共の工夫 と注意すべき点を供覧する。

【方法】胃全摘術後、Treitz靬帯から約 $20 \mathrm{~cm}$ の部で空腸 を切離し、遠位側切離端から約 $50 \mathrm{~cm}$ の空腸で pouchを作 製し、食道十二指腸間に間置する。移植空腸の採取に

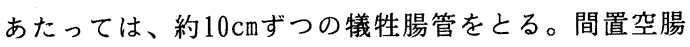
の内 $15 \mathrm{~cm}$ p pouchとし、 $15 \mathrm{~cm}$ 順蠕動性の排出腸管とし た。pouchの最も食道吻合側の隔壁は、血流温存を目的 に、打ち抜かず温存する。必ず粘膜面から出血の有無 を観察し、必要に応じて吸収性の縫合系で縫合止血す ることが肝要である。食道空腸吻合は器械吻合で行っ ている。

【結果】本法は従来のRoux-Y法にくらべ食事撕取量の 増加がえられ、各栄養指数の改善が比較的早期にみら れた。良好な患者QOLを得るような再建法の工夫につい て討論したい。

\section{8 旰切除術における術中ナビゲーターとし ての3 次元超音波画像 (3 D - US )}

慶應義塾大学外科、GE横河メディカルシステム* 島津元秀、大上正祐、若林 剛、隈元雄介 唐橋 強、都筑俊治、北島政樹、橋本 浩* 肝切除術において術中超音波検查は病変の局在、肝 内脈管の走行などを把握し、正確な肝切離や脈管処理 を行う上で久くべからざる検查である。しかし、検者 は直接得られる 2 次元断層画像を頭の中で 3 次元画像 に再構筑する必要があり、検者によってその再構筑力 すなわち 3 次元的理解の程度に差があるため、客観性 に劣る難点がある。我々は C T、MR I などの画像処 理で用いられている画像投影法を超音波に応用し、さ らに超音波の” 実時間”といら特長を損ならことなく 術中超音波画像を 3 次元表示する装置を開発した。こ れにより従来、検者の超音波診断技術に依存していた 肝内病変・脈管の立体的把握が容易かつ客観的となり、 肝切離求よび脈管処理の正確性、安全性が向上した。 現在までに 3 次元超音波画像（3 D-US）をナビゲ 一ターとした肝切除を 10 例に施行したので、 $3 \mathrm{D}$ U S の実際ならびにそれを用いた肝切除術をビデオに て供覧する。
239 高出力電気メス(Cautery with Irrigation Forceps:CIF)を用いた肝切除術一CUSAと比較してー 山口大学第二外科

清水良一, 西田峰勝, 嗵脇一久, 前田義隆, 中島一毅, 平木桜夫, 高尾康一郎, 高尾貴史, 岡 正朗, 鈴木 僘

[目的] 従来、教室では超音波メス(CUSA)による 肝切除を施行していた。しかし、最近の 1 年半は単極 の高出力電気メス( Cautery with Irrigation Forceps : CIF) を使用することで、残存肝の血行を遮断するこ となく安全に肝切除を行いえている。CIF は特別な 手術器具ではなく、どの施設にでも備わっている器具 および備品を用いて術中にでも、その場で簡単に作製 できるという利点を有する。今回、この教室で開発し たCIFを使った肝切除術を供覧し、要点を解説する。

[対象と成績] CIFによる肝切除を評価するために、 CUSA および CIFを用いた区域切除以上の肝切除症例 (CUSA群44例, CIF群15例)について、手術時間、術 中出血量、術後の肝機能の推移を検討した。その結果、 平均の手術時間(各々約6時間半)には差はなかったが、 術中の出血量はCUSA が $2437 \pm 598 \mathrm{ml}$ であったのに 対してCIF は $1020 \pm 147 \mathrm{ml}$ と、CIF を用いた群の成績 が良好であった。術後の肝機能の推移でも、CUSA群 に比較して、CIF群では同等かそれ以上の良好な成績 が得られた。CIFは安全で安価な手術器具である。

240

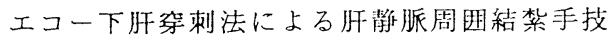
昭和大学藤が丘病院外科

緑川武正、菊地浩彰、朾田宏、志村浩、金潤吉、 酒井均、高用茂、中野浩、高橋博義、八木秀文、 成原健太郎、真田 裕、熊田 蕃

肝切除術時における出血のコントロールは術後成 績を大きく左右する。特に肝静脈系の出血を制御する ことは最大の鍵である。最近、我々はその制御にあた り、肝上部側の肝静脈凬用をエコー下に染刺し結紮亦 るという試みを行っている。方法はエコー下に下大静 脈と肝静脈の間隙を血管留犆カテーテルで穿刺し、そ こに太めの結紮糸を通し結紮するというものである。 穿刺のコッは、切除側の肝上部下大静脈周四を十分䣋 耀した後、エコー下に下大静脈と肝静脈の間隙を穿刺 するのであるが、第刺時に肝静脈分枝の損傷に十分注 意することが大切で、呀刺部位は下大静脈流入部より 約 $2 \mathrm{~cm}$ 程末梢が安全である。肝門流入血のコントロー ルはグリソンの片側クランプを行っている。本手技は これまで大腸癌肝転移例の左葉切除、右葉切除、拡大 右葉切除、並びに硬変合併肝癌の右下区域切除、左外 側区域切除に応用した。結果は全例術中出血 $200 \mathrm{~m} l$ 以 下で、肝葉切除などに扔ける肝静脈破綻出血の制御に 有用と思われる。 
要区域切除術

岐皁大学第 1 外科

鬼束停義、柴田雅也、今井直基、角泰廣、

福地貫彦、二村直樹、山内希美、千賀省始、

林勝知、広瀨一

教室では肝切除にあたり、1985 年以来、切除範 曲の絡小と肝門部の一時的血行遮断を導入した。以来 、手術死亡は皆整となり、それ以前に施行した症例に 比し出血量は有意に低下した。要区域以下の切除に当 たっては、出来るだけ小範曲の一時的血行進断にとど めるため、S 6 あるいはS 7 の切除にあたっては閶脈 ・動脈とも右枝のみの血行遮断を、S 5 或いはS 8 の 切除にあたっては䏕動右枝および左枝、閏脈前区域 枝、後区域枝、左枝をそれぞれテーピングし、切離部 に応して責任区域枝を遮断している。前・後区域枝の クリリン鞘一括処理にての遮断を行うな場合もある。 本法を用いてS 5 またはS 8 垔区域切除、あるいは同 部の部分切除を施行したものは23例である。今回は 責任区域門脈枝一時的進断下における S 8 部分切除術 を供覧する。

[結論]血行遮断による残存肝の機能傷害を少なくす るため、遮断範囲は必要最低限にとどめるべきであり 本法は有効な方法であると考える。

腹による肝切除術一血管処理を中心に

札幌厚生病院外科

高橋雅俊、片岡昭彦、中村隆志、岡田邦明

石津寛之、益子博幸、西田靖仙、小川秀彰

横山良司、近藤征文

横隔膜浸潤合併肝癌の肋骨弓切離、横隔膜切開によ る肝静脈処理を中心に当科の肝切除術式を示す。

1. 正中と右肋間に向かう切開を行ない、肋骨弓切離 後に横隔膜を切開する。2. 肝十二指腸間膜リンパ節を 郭清し、肝動脈、門脈、胆管を露出。右肝管は、刺通 結禁を行う。上腸間膜動脈より分岐した右肝動脈を膵 上縁で切離。門脈は、切離後、血管縫合系にて連続縫 合を行う。短肝静脈を処理した後、浸潤部横隔膜を切 離し、右肝静脈を右側面より剥離、広い視野で切離、 血管繾合系による連続䋖合を行う。肝切離はbipolar LASER dissectorと超音波メスで行なう。直径 $1 \mathrm{~mm}$ 以下 の脈管はbipolar LASER dissectorにて切離するが、こ れ以上の脈管は結禁後、切離する。

【結語】1. 横隔膜浸潤合併肝癌では開胸開腹による横 隔膜切除を行ない、広い視野で安全に肝静脈を処理で き、肝受動操作を最小限にすることができると考える。 2. bipolar LASER dissectorと超音波メスによる肝切除 は出血も少なく、安全な切離法と考える。
244

広島大学第二外科 ${ }^{11}$, 県立広島病院第一外科 ${ }^{21}$, 中国 労災病院外科 ${ }^{3}$

浅原利正、土肥雪彦、福田敏勝、矢野将嗣、

日野裕史、越智誠、岡本有三、中原英樹、田中恒夫、 丸林誠二、八幡浩、福田康彦 ${ }^{11}$ 、板本敏行、

田中一誠、大城久司 ${ }^{21}$ ，片山幸治、江藤高陽 ${ }^{31}$

[目的] 尾状葉肝癌特に尾状葉下大静脈部肝癌に対す る安全な肝切除方法を検討する。

[対象、結果、考察] これまでに尾状葉肝癌に対し肝 切除を行った症例は14例（肝細胞癌10, 転移性肝癌4） である。術式は突起部切除3 例、肝左葉十尾状葉切除 3 例、尾状葉単独切除8 例であった。下大静脈部肝癌 に対して、肝硬変の無い転移性肝癌では肝左葉と共に 尾状葉切除するのが安全、確実である。尾状葉単独切 除では、血流遮断はPringle 法を用いている。切除に 際しては電気メスとCUSAが一体となったオリンパス社 製のCUSAが深部にて吸引、凝固、切開が容易であった。 切除のポイントはまず短肝静脈の確実な処理、腫瘍と 接した肝静脈を損傷しないような操作が肝要で、肝静 脈の枝を抜いてしまうと肝静脈からの止血に難渋し、 空気塞栓を生じる結果となる。また視野の悪い門脈か らの止血も容易でないことが多く、胆管と同様細い門 脈の処理も丁寧に行うことが重要である。

245 肝切除における controlled method変法 九州大学第 2 外科

矢永勝彦、竹中賢治、島田光生、西崎 隆、

調憲、武畐紹信、川原尚行、藤原 雄、

祇園智信、杉町圭蔵

[目的］controlled method変法による肝切除法の呈示。

[術式 1] 選択的全肝阻血下肝切除法

肝の右側または左側への脱転下に短肝静脈を結紮切

離し、尾状葉を下大静脈から遊離させ、肝が主肝静脈 のみで下大静脈に接続するまで剥離を行い、Pringle法 と主肝静脈の下大静脈合流部での一括遮断により、下 大静脈血流を温存しつつ選択的に全肝阻血を行い、肝 切離を行う。傷害肝の尾状葉単独切除などに適する。

[術式 2] 経臍静脈的肝内門脈遮断による肝切除 肝円索内の臍静脈経由で肝内門脈へ迅速な到達が可 能である特性を肝切除に応用する。その手技は、肝円 索内に臍静脈を同定し、閉塞した臍静脈を拡張、再開 通させ、8 Fr のFogartyカテーテルを挿入し、エコー監 視下に目的とする肝内門脈枝を選択的に閉塞した上で 肝切離を行う。肝門部未処理下の肝切離が容易となる。

[術式 3 ] 器械吻合器を使用したグリッソン鞘一 括離断による肝切除術

器械吻合器を使用したグリッソン鞘一括離断により 容易に肝流入血行遮断を行う。 
246

\section{予後の検討}

久留米大学第 1 外科

青柳慶史朗, 孝富士喜久生, 児玉一成, 大田準二, 武田仁良, 白水和雄

[目的] 癌抑制遺伝子である p53,p21 はアポトーシ スとの関連についても注目されているが、胃癌組織に おける発現に関する報告少ない。そこで、今回胃癌組 織における p21, p53 の発現と予後について免疫組織学 的検討を行った。［方法］胃癌組織 75例の凍結切片を 対象とした。 p53, p21の各モノクロナール抗体を用い て $\mathrm{ABC}$ 法にて免度組織学的染色をおてなった。[結果] $\mathrm{p} 53$ 陽性例は 22 例 $(29.3 \%), \mathrm{p} 21$ 陽性例は 16 例 $(21.3$ $\%$ )であり、p53, p21 ともに陽性をしめす症例は 5 例 (6.7\%)であった。p53のみ陽性を示す症例をA群, p21 のみ陽性を示す症例を B 群，両者陽性を示す症例は C 群，両者陰性を示す症例を D群とすると、Stage III, $\mathrm{N}$ の割台は A群 $88.2 \%$, B群 $9.1 \%$, C群 $100 \%$, D 群 $71.4 \%$ B群が A, C, D群に比し低率であった。3 年生 存率は $\mathrm{A}$ 群は $0 \%, \mathrm{~B}$ 群は $100 \%, \mathrm{C}$ 群は $60 \%, \mathrm{D}$ 群は $51 \%$ で、A群は B，D群に比へ予後不良であり、B群は $\mathrm{A}, \mathrm{C}, \mathrm{D}$ 群に比べ予後良好であった。[まとめ] p53は 進行例, 予後不良例に発現が認められた。一方、p 21 は早期例, 予後良好例に発現が認められた。

247 大腸癌・食道癌におけるMAGE遺伝子の発現 滋賀医科大学第一外科

西村彰一、藤田益嗣、寺田信國、内藤弘之

目片英治、谷徹、柴田純祐、小玉正智

[目的] MAGE( melanoma antigen) genekよって コードされる腫瘍退縮抗原はHLA拘束性に細胞障害性 T細胞を誘導する。われわれは、大腸癌および食道癌 手術症例におけるMAGE遺伝子の発現を RT-PCR法およ び in situ hybridization法をもちいて検討した。 [方法]当科にて切除した大腸癌 16 例 - 食道癌15例に ついて、MAGE-1, -2, $-3,-4 \mathrm{a} / 4 \mathrm{~b},-3 / 6$ に特異的なプラ イマーをもちいてRT-PCRをおこない、MAGE遺伝子の発 現を検出した。また、in situ hybridization法によ る組織切片上におけるMAGE mRNA発現の局在について 検討した。[結果]大腸癌手術症例に打ける腫瘍組織 での MAGE mRNA発現は10/16(62.5\%)であり、大腸癌腫 瘍組織全体にhomogeneousに認めた。食道癌手術症例 における発現は10/15（66\%）であり、大腸癌と異なり 食道癌腫瘍辺縁部に強く認めた。［考察］MAGEを使っ た特異的癌免疫療法の対象として大腸癌・食道癌は有 望であるといえる。腫瘍の組織型の違いによってMAGE mRNAの発現の局在が異なると考えられ、MAGEをむち いた特異的癌免疫療法において組織型によって治療効 果に違いを生じる可能性があると考える。
248

RT-PCR法を用いた末梢血、門脈血及び骨 髄中の膵癌、胃癌細胞の検出一潜在性血行性転移診断へ の試みー

大阪府立成人病センター外科 1 、大阪大学医学部第 外科 ${ }^{2}$

相原智彦 ${ }^{1.2}$ 、野口眞三郎 1 、石川治 1 、古河洋 ${ }^{1}$ 、大東 弘明 ${ }^{1}$ 、平塚正弘 ${ }^{1}$ 、中森正二1、甲利幸 ${ }^{1}$ 、佐々木洋 ${ }^{1} 、$

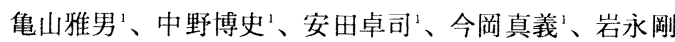
1、門田守人 ${ }^{2}$

【目的】サイトケラチン19(K19)のmRNAを多ー゙ットとした RT-PCR法により末梢血、門脈血及び骨髄での膵癌及び 胃癌細胞の検出を試みた。【対象】膵癌26例について、 末梢血及び門脈血を採取し、細胞診とRT-PCRに用いた。 胃癌10例でも末梢血、門脈血及び骨髄について検討した。 【結果】検出感度は膵癌細胞10個/血液 $5 \mathrm{ml} ゙$ あった。脺 癌では末梢血はstageI-III10例すべて陰性、stageIV6/15例 が陽性、門脈血はstageI-II 5例で陰性、stageIIIの3/6例、 stageIVの7/15例が陽性であった。胃癌ではstageI-IVbの末 梢血は10例すへててで陰性で、stageIIIaの $1 / 4$ 例の門脈血及 び骨髄の、stageIVbの1/4例の門脈血が陽性であった。 【結論】K19 RT-PCRは感度が高く血中の膵癌及び胃癌 細胞の検出に有用であると思われた。

249 リンパ節転移を有する食道癌の予後因子

として転移リンパ節の細胞増殖活性測定の意義 鳥取大学第 1 外科

池口正英, 堅野国幸, 岡 淳夫, 柴田俊輔, 辻谷俊一, 前田迪郎, 貝原信明

[目的］主癌巣および転移リンパ節での癌細胞の細胞 増殖活性を比較し, リンパ節転移を有する食道癌の予 後因子として転移リンパ節の細胞増殖活性測定の意義 につき検討した。 [対象] 術前無治療の食道癌症例で 根治度 0 度を除く95例を対象とした。［方法］主癌巣， 転移リンパ節のAgNOR scoreおよびKi-67 labeling index （LI)を算出した。 [結果] 主癌巣のAgNOR score, Ki67 LIはリンパ節転移陰性. $(\mathrm{n}(-)) 42$ 例で $3.8 \pm 1.1,38.1 \pm$ 13.9, 転移陽性 $(\mathrm{n}(+)) 53$ 例で6.1 $1.8 ， 57.1 \pm 14.4$ と, $\mathrm{n}(+)$ 例の主癌巣の細胞増殖活性はn(-)例に比べ有意に高 值であった。一方, 転移リンパ節75病変の AgNOR scoreと Ki-67 LIは5.3土1.9，44.7士17.1で，n(+)例の主 癌巣に比べ低值であった。耐術生存81例の 5 生率は, $\mathrm{n}(-)$ で74\% (n=32), $\mathrm{n}(+)$ で17\% $(\mathrm{n}=49)$ と, $\mathrm{n}(+)$ 例の予 後は不良であった。 $\mathrm{n}(+)$ 例中, 転移リンパ節のKi-67 LIが主癌巣のそれより下降した 31 例の 5 生率は $29.4 \%$ に対し，上昇した18例は全例 2 年以内に再発死亡した. [結語] 転移リンパ節において癌細胞が高い増殖活性 を示す症例の予後は極めて不良と考えられた。 
250

原発性肝細胞癌における Ki-67、P.53蛋

白の予後判定因子としての有用性について

順天堂大学第2 外科

吉本次郎、岩田豊仁、須郷広之、行方浩二、渡邊 心、 奥山耕一、児島邦明、深沢正樹、別府倫兄、二川俊二

(目的) Ki-67、P-53蛋白の予後判定因子としての可 能性につき検討した。

（对象および方法）肝切除で得られた癌組織56検体、 非癌部組織 47 検体、肝生検にて得られた肝硬変組織 16 検体をホルマリン固定、パラフィン包埋し、マイ クロウェーブにて加熱後、MIB-1抗体(immunotech S.A.)、DO-7(DAKO)を一次抗体として、ABC法にて 免疫染色を行なった。

(結果) 癌部のKi-671abeling rateは（1）非癌部に 比べ、有意に高值を示した。（2）im陽性の症例では 陰性例に比べて有意に高値であった。また、vp陽性、 fc·inf陽性、a neuploid症例、低分化の症例で高值を示 す頃向を認めた。（3）術後12 カ月以内で再発した症 例では、12力月以降に再発した症例に比べ、有意に 高值を示した。（4）P-53染色陰性症例に比べ、陽性 症例で有意に高值であった。また、P-53染色陽性率 は低分化型で高値であった。（結語）肝細胞癌におけ る悪性度評価に、癌部におけるKi-67labeling rateが 有力な一助になる可能性が示唆された。

251 大腸癌における細胞遺伝学的解析と臨床 病理学的諸因子及び予後との関連 長崎大学第 1 外科

七島篤志、田川泰、中越享、安武亨、

宮下光世、山口広之、澤井照光、地引政晃、

森永真史、赤間史隆、綾部公鼔

[ 目的]今 回Fluorescence in situ hybridization (FISH)を用いて 153例の大腸癌切除標本の解析を行い 臨床病理学的諸因子と予後について検討した。

[方法］1985年より10年間に得られた大腸癌のパラフィ 包埋組織、凍結組織及び生標本の単離細胞を用いて,核 DNA量解析、7、8、11、17、18、20、14/22(combined)番染色 体の数的異常について解析した。[結果及び結論]

DNA aneploid は62\%に, 各染色体数的異常は $60 \%, 77 \%, 64 \%, 71 \%, 72 \%, 55 \%, 96 \% に$ 認めた。核DNA量, 7番,8番染色体異常はいずれの因子とも関連はなかっ た。腫瘍径・深達度・進行程度による大腸癌の進行には 11,17 番染色体数增加と 18 番染色体数減少か、肝転移に は 11,20 番染色体数增加と 14/22番染色体数減少が関連 があった。11,17番染色体数減少は術後の予後良好で、 逆に18番染色体数減少は予後不良因子であった。ある 種の染色体数的異常の解析は、大腸癌の臨床病理学的 な補助診断及び切術後の予後因子として有用と考え た。
252 食道癌における遗伝子異常からみた生物学

的悪性度一retrospective \& prospective study慶應義塾大学外科

小澤壯治, 上田政和, 安藤暢敏, 池田佳史,

篠崎浩治, 北島政樹

【目的】cyclinD1遗伝子とc-erbB遗伝子の異常を分子 生物学的手法により解析し, 食道癌の生物学的悪性度 について検討した.【retrospective study】 cyclinD1増 幅は食道癌122例中28例(23\%)に認められた. 術後生存 率は増幅群で不良であった $(\mathrm{P}<0.001)$. 臓器再発は cyclinD1増幅と関連していた $(\mathrm{P}<0.01)$. c-erbB増幅は 107例中13例(12\%)で, 術後生存率は増幅群で不良であ った $(\mathrm{P}<0.001)$. 手術時リンパ節転移はc-erbB増幅と関 連していた $(\mathrm{P}<0.01)$.【prospective study】術前の内 視鏡生検組織と外科切除組織の遗伝子増幅を58例につ いて比較した．正診率はcyclinD1で $90 \%$, c-erbBで $100 \%$ と内視鏡生検により遺伝子㭘査が可能と考えられた. cyclinD1増幅は96例中32例(33\%)で, 増幅群の予後が不 良であった $(\mathrm{P}<0.05)$. 遠隔葴器再発とcyclinD1増幅が 関連していた $(\mathrm{P}<0.01)$. c-erbB増幅は82例中8例 $(10 \%)$ で, 増幅群の予後が不良であった $(\mathrm{P}<0.05)$.【結論】 cyclinD1増幅は予後因子および臟器転移予測因子, c$e r b B$ 増幅は予後因子およびリンパ節転移予測因子と考 えられた.

253 胃癌におけるCD44 mRNA の発現と予後

関西医科大学第 2 外科 ${ }^{11}$, 同附属肝灌研究所 ${ }^{21}$,

東京工業大学生命理工学部生命理学科 ${ }^{3)}$

山道啓吾1)，上原芳彦2)，喜多村直美3)，朴常秀11，

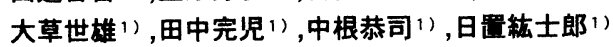

（目的）接着分子CD44は癌の枟移に閲連しているとい われている。今回, 胃癌組織においてCD44mRNAの発 現量を定旦し,転移,予後との関連を検討した。

（対象および方法）当科で切除した置癌症例69例を対 象に新鮮凍結保存した胃噟組織(T)および隣接非癌組織 (N)からtotalRNAを抽出し, RT-PCR/Southern blot 法でCD44 standard(CD44s),v6,v9 mRNA の発現量 を定目した。Image analyzer で数值化, T/N比を算出 し,CD44 mRNAの発現量を侮床病理学的に検討した。

(結果) CD44s,v9の発現量はいずれの臨床病理学的因 子とも開連性を㒛めなかった。v6の発現量は進行例で 増加し,リンパ節転移およひ肝転移と有意に相関した。 治疼切除44例における予後との検討では血行性転移例 のv6の発現量が有意に增加していた。また,v6高発現群 ( $\mathrm{T} / \mathrm{N}$ 比 $\geqq 2.5)$ 予後が有意に不良であった。

(結語) 胃癌組織においてCD44 v6 mRNA 発現昷の増 加は枟移,再発の危険性を予知するための有用な予後因 子になる可能性が示唆され、発現量を定青、数值化す ることにより客観的な判定が可能になると考えられた。 
254

およびmulticentricityの検討

肝細胞癌 (HCC) におけるMonoclonality

大阪市立大学第二外科 (1), 第二病理2), 病理部3),

大阪大学産婦人科4)

奥田豊-1), 広橋一裕, 久保正二, 木下博明, 桜井幹 己2), 若狭研一3), 八幡朋子, 榎本隆之4), 藤田征巳

〔目的〕今回我々は女性のHCC，AHに扔ける，X染 色体上のAndrogen Recepter (AR)遺伝子のメチル化のパ ターンを解析することで癌化の極初期段階までに規定 されているX染色体の不活化パターンから， HCC, AH のclonalityを検索した。また多発結節については転移か 多中心性発生かを検討した。【対象·方法】当科で切 除されたHCC（女性）22例を対象に，それぞれの㿋 部, 非癌部, 前癌病変であるAHよりDNAを抽出した。 メチル化によって不活化されていないアレルを制限醳 素で消化し，これを鋳型としPCRでAR遺伝子のexon 1 のCAG repeatを含む領域を増幅, bandを検出した。 〔結果〕ARのhetero接合性を示したのは22例中21例（ 95.5\%) であった。非癌部は全例polyclonalなパターン を示し，癌部の24結節すべてのみならず, 前癌病変AH の3結節でも monoclonalであった。また多発結節であっ た3例は同側のアレルが不活化されており，転移性腫瘍 である可能性があったが, 他の遺伝子変化の解析から も現在検討中である。

マ师ラ隹ンを標的遺伝子とした大腸癌細胞の浸潤抑制 横浜市大第 2 外科 ${ }^{1)}$, 同木原生物学研究所 ${ }^{2)}$, Hitachi

Chem. Res. Ctr., USA ${ }^{3)}$

料山信義占, 石川 孝, 市川靖史, 越川直彦 ${ }^{2)}$, 宮崎 香, 三橋将人 ${ }^{3)}$, 嶋田 紘 ${ }^{1)}$

【目的】アソチセンス杖ゴ(AS) の至適設計条件を確立し，マ忡 ラ隹ASによる大腸癌細胞の浸潤抑制効果を検討する。

【方法】(1) AS設計基準 : 癌遺伝子c-jun, c-fos, c-myc に対して長さ, Tm 值, 標的部位の異なる杪ゴを合成し、 白血病細胞株 U937に対する細胞増殖抑制効果の違いを 検討した。(2) マ师ラ隹 合成したマ师ラ隹ンAS (AS-1)及びュットロール才リリ゙(CL-1)を大腸 癌細胞株CaR-1に作用させ、(1)mRNA発現, (2)蛋白合成, (3)マ訬ジェルに対する細胞浸潤能, に及ぼす効果を検討し た。

【成績】(1) c-jun, c-fos, c-mycいずれの標的遺伝子に対 しても、長さ $15 \mathrm{mer}, \mathrm{Tm}$ 值 $35^{\circ} \mathrm{C}, 5^{\prime}$ 領域を除く標的部位 をもつオリ゙は、有意に高い細胞増殖抑制効果を示した。 (2) AS-1の効果 : AS-1はマ师倠・mRNA, 蛋白の発現を抑 制し、CaR-1細胞の浸潤能を有意に阻害した。CL-1は、 いずれの効果も示さなかった。

【結論】大腸癌の浸潤・転移に対するアンチセノス療法の可 能性が示唆された。
256 テロメラーゼ活性のnon-RI測定法の確立

とその臨床応用への可能性

札幌医大第一外科 ${ }^{11}$ 、同第一病理 ${ }^{21}$

和田好正 ${ }^{1)}$ 、八木橋厚仁 ${ }^{1)}$ 、松浦晃洋 ${ }^{2)}$ 、菊地浩吉 ${ }^{21}$ 、 佐々木一晃 ${ }^{1)}$ 、平田公一 ${ }^{1)}$

癌化した細胞はテロメラーゼを活性化させ、自身を 不死化する。この事実に基づき、テロメラーゼ測定を 癌の診断に応用したり、さらには新しい癌治療戦略と してテロメラーゼ阻害による効果が研究され始めてい る。さらに、癌患者の予後はテロメラーゼと相関する という報告も散見され始め、この酵素の臨床的意義が 今後明らかにされていくことであろう。しかし、テロ メラーゼ活性を簡易にしかも高感度で測定する方法が ないことが研究拡大の支障となっていた。われわれは PCR法により、RIを使用せずに検出する方法を確立した のでその有用性について報告する。

教室で樹立された萟癌細胞株よりテロメラーゼを抽 出、PCRにて増幅し、digoxigeninでラベルしたプローブ を用いてサザンブロットにて検出した。その結果、 $10^{3}$ 個の細胞からテロメラーゼ活性が検出できることが判 明した。さらに、教室で切除した手術材料を対象とし て検討したところ、癌部のみテロメラーゼが検出され た。現在は細胞診や組織診での有用性、あるいは患者 の予後を判定する因子となりうるのか検討をしている。

257 Invasion-MTT Assayによる消化器癌の

肝転移の予測とそのメカニズムの検討

鹿児島大学第 1 外科

高尾尊身、今村芳郎、有村耕一、松山義人、植村 勝男、大迫 保、今村 博、山田一隆、愛甲 孝

【目的】Invasion-MTT Assayの肝転移予測への臨床応 用の試みとそのメカニスムの検討を行った。【材料 と方法】ヌードマウス移植消化器癌と新鮮摘出腫瘍 を用いて以下の検討をした。1)Invasion-MTT assay : Matrigelを浸潤通過した癌細胞数をMTT assayで定 量、百分率をPercent Invasion(PI)と定義 (Cancer Res, 1994)2)Adhesion assay3)(hemotaxis assay4) Collagenase activity assay5)Gelatin Zymography によるMMP-2,MMP-9の検討6) EIAによるTIMP-1、TIMP2の定量【結果】1)ヌードマウス移植腫瘍の肝転移 + )群のPI值 $(1.5 \pm 0.49)$ は、肝転移 $(-)$ 群のPI値 $(0.5$ $\pm 0.49)$ より有意に高く、2)新鮮手術材料の肝転移 十)群でもPI值 $(>1.0)$ は、肝転移(-)群より有意に高 く、術後に肝転移を来した症例も高值を示した。3) 膵癌のコラゲナーゼ活性は高く、肝転移 $(+)$ 群は $(-)$ 群より有意に高値で、MMP-2>MMP-9の発現傾向（大 腸癌ではMMP-9>MMP-2）を示した。5)膵癌のTIMP-2 濃度は大腸癌より高值であった。【考察】基底膜浸 潤能にMMP-2、MMP-9が強く関与し、TIMP-2は肝転移 を高頻度で生じる膵癌で高いことからMMPとTIMPとの 量的バランスが浸潤能を規定していることが示唆さ れた。Invasion-MTT assayは肝転移の予測または予 後因子として臨床応用の可能性が示唆された。 
258

肝転移抑制におけるtis sue

plasminogen activator (tPA) 遺伝子導入による遺伝 子治療の有用性について

名古屋大学医学部第二外科

林 衆治、波井 康、小林孝彰、長坂隆治、小島泰樹、 片山昭男、小池千裕、横山逸男、高木 弘

（目的）欧米では先天性代謝性疾患、悪性腫瘍に対し て遺伝子治療が行われつつある。今回我々は、大腸癌 肝転移を抑制する目的でtis sue plasminogen activat or (tPA) 遺伝子を用いて遺伝子治療の有用性に 関して検討した。

(効果と方法) マウス大腸癌細胞Colon 26を用いて、 肝転移、腹膜転移を作成した。レトロウイルスベクタ 一MFGtPAを用いてColon26に遺伝子導入を行った。 遺伝子導入はELISAにより確認。Colon 26/tPAの増殖 能はMTT法により測定した。

(結果及び結論) Colon26を用いた肝転移マウスでは 平均生存21.7日であるのに対してColon 26/tPAを用い た場合、全例100日以上であった。以上よりtPA遺伝子 導入による遺伝子治療は肝転移抑制に有用であると考 えられた。

260

膀㾇におけるvacuolar type proton pump (V-ATPase)発現の意義ならびにproton punp inhibitorを用いての膵癌治療戦略についてー-とくに, 癌細胞 内acidification と apotosis誘学に関連して-金沢大学第二外科 ${ }^{1)}$, 同 解剖 ${ }^{2)}$, 同 菜学部生化 ${ }^{3)}$ 太田哲生 ${ }^{1)}$, 山本美闻紀 ${ }^{2)}$, 沼田雅行, 井関尚一, 大熊勝治 ${ }^{3}$, , 中川原寿俊 ${ }^{1}$, 八木治雄, 荒川 元, 二上文夫, 北川裕久, 荁原正都, 永川宅和, 宮崎冕夫 [目的] 本研究では, 固形富のなかても悪性度が高く て予後の悪い膵癌を対象にV-ATPaseの発現を検索し， V-ATPaseのinhibitorであるbafilonycin $A_{1}$ が膆癌細胞 の至適pHを変えて，その增殖を抑制(apoptosisを誘導) するか否かを研究した. [材料と方法]14例の新鲜切除 標本(膵癌 12 例, 正常膵 2 例) と 6 種類のヒト膆癌細胞株 を用いた。V-ATPaseの発現は口RNAと蛋白レベルで検索 した.また, bafilonycin $A_{1}$ の增殖抑制効果は in vitroとinvivoの実臨を行って評便した. [結果]膵癌 細胞はV-ATPaseを過制に発現し, protonの移動を通し て細胞内オルガネラや細胞質のpHを调節して增殖に至 通な㻴境作りをしている可能性が示唆された。また， bafilouycin $A_{1}$ で癌細胞のapoptosisが誘導されて增殖 が抑制された.[まとめ]以上の成䋶より,V-ATPase過利 発現の固形癌に対してはproton pump inhibitorを用い ての新しい癌治療戦略の可能性が見いだされた。
261 ヒト大腸癌細胞株WiDrにおけるbutyrate によるWAF1/Cip1遣伝子の発現誘導 ; 癌の「転写調 節化学療法」のモテルとして

京都府立医科大学 2 外科 ${ }^{12}$ 、同公衛 ${ }^{2)}$

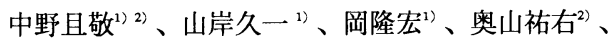

曽和 義広 ${ }^{2)} 、$ 藤田剛 ${ }^{2)}$ 、松川義純 ${ }^{22}$ 、酒井敏行 ${ }^{2)}$

[目的・方法］ヒト大腸癌細胞株WiDrにbutyrateを添加 し、その増殖抑制効果を検討すると同時に、WAF1/Cip1遺 伝子の発現誘導を検討した。さらに同プロモーター活性 に対するbutyrateの効果と、flow-cytometerによるDNAヒス トグラム解析を検討し、新しい化学療法の可能性を検討

した。 [結果] butyrateは、G1期停止を伴って細胞増殖を 抑制し、WAF1/Cip1の発現誘導及びそのプロモーター活性 の著明な増強を認めた。[考察] WiDrは、p53遺伝子変 異を有しており、butyrateの増殖抑制効果は、p53非依存性 にWAF1/Cip1を発現誘導することによる可能性が示唆され た。WAF1/Cip1は、p53の増殖抑制作用に直接関係する細 胞周期関連遺伝子として注目されており、p53非依存性に WAF1/Cip1を発現誘導することは、p53が失活している悪 性腫瘍に対する新しい化学療法につながる可能性があ る。今回の実験結果は、これを支持するものであり、こ のように、温存されている細胞周期関連遺伝子を転写レ ベルで活性化し、癌を治療（予防）する方法を、我々は 「転写調節化学療法 (予防)」と命名し、今後の新しい 遺伝子療法として期待している。

262

トーシス検索の意義 一基礎的・臨床的検討一

九州大学第二外科

大野真司、友田政昭、冨崎真一、山本学、織田信弥、 北村薰、市吉裕二, 杉町圭蔵

【はじめに】消化器癌治療におけるp53遺伝子とアポ トーシス検索の意義を検討した。【対象と方法】1. 基礎的検討 消化器癌12細胞株にて、p53遺伝子異常 をRT-PCR法で、抗癌剤処理後のアポトーシスをDNA ladderingにより検出した。2. 臨床的検討 術前温熱 · 化学・照射療法施行直腸癌34例を対象に、p53遺伝子 異常と組織学的治療効果・遠隔成績・アポトーシスと の関係を検討した。【結果】1. 基礎的検討 p53 wild type3株では抗癌剂処理後にDNA ladderingがみられた が、p53 mutant 9株ではDNA ladderingは認められなかっ た。2. 臨床的検討 正常p53発現16例では著効6例 (38\%) と有効 9 例 $(56 \%)$ 、異常 $\mathrm{p} 53$ 発現 18 例では著効 4 例 $(22 \%)$ と有効 8 例 $(44 \%)$ であった。5年生存率は正常 $\mathrm{p} 53$ 発現症例 $86.5 \%$ と異常 $\mathrm{p} 53$ 発現症例 $53.0 \%$ で $(\mathrm{P}<0.05)$ 、 アポトーシスは正常p53発現症例62.5\%(10/16)、異常 $\mathrm{p} 53$ 発現症例 $11.1 \%(2 / 18)$ であった $(\mathrm{P}<0.05)$ 。まとめ】 抗癌剤治療におけるアポトーシス誘導には正常 $\mathrm{p} 53$ 遺 伝子の関与が必要であり、また直腸癌に対する術前治 療効果とp53遺伝子発現には有意な相関が認められた。 
263

消化性潰崲合併症に対する Helicobacter

pylori 感染の関与 : 胃液中 H. pylori DNA および

cytotoxin gene( cagA, vacA) の解析

日本医科大学第 1 外科

松倉則夫、恩田昌彦、徳永 昭、白川 毅、瀧田雅仁、 寺本 忠、小栗 剛、木山輝郎、吉行俊郎、加藤俊二、 山下精彦

【目的】H.pylori 感染と第孔、出血などの消化性潰瘍 合併症との関係は不明である。今回十二指腸潰瘍穿孔症 例および胃潰瘍出血症例之、性、年齢を揃えた非穿孔、 非出血胃十二指腸潰瘍症例で H. pylori 感染の casecontrol study を行なった。【症例と方法】呀孔性十二 指腸潰崵 14 例、matched control として非穿孔十二指腸 潰崵 27 例、および出血性胃潰瘍 8 例、control として非 出血性胃潰湯 35 例。胃液中 H. pylori DNA は PCR 法で增 幅後、電気泳動及び Southern hybridization で同定し た。cagA、vagA遗伝子もPCR 法で検索した【結果】十二 指腸潰瑒穿孔vs 非穿孔十二指腸潰煬：胃液 PCR 陽性率 $100 \%$ vs $96 \%$, cagA 陽性率 $85 \%$ vs $89 \%$ 、vagA $169 \%$ vs $82 \%$ ， cagA $62 \% v s 78 \%$ と穿孔症例と contro1 間に有意差を認めない。 出血性胃潰瘍 vs 非出血性胃潰瘍: 胃液 PCR 陽性率 $100 \%$ vs $100 \%$, cagA 陽性率 $88 \%$ vs $97 \%$ 、vagA $63 \%$ vs $74 \%$ 、vagA $63 \%$ vs $77 \%$ と出血症例と control 間に有意差を認めず、消 化性潰瘍合併症への H. pylori の関与は少ない。

264 キメラ化モノクローナル抗体を用いた膵癌 免疫シンチグラフィーの検討

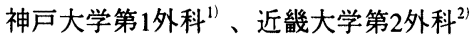

神垣 隆 $^{1}$ 、山本正博、大柳治正 ${ }^{2}$ 、斎藤洋一 ${ }^{1}$

【はじめに】近年、癌細胞に特異的に結合するモノク ローナル抗体（MAb）によるイメージングが試みられ ている。今回、消化器癌に高率に反応を示し、ヒト定 常領域を有するキメラ化 MAb A10による膵癌のイメー ジングへの応用の可能性について検討した。

【方法】キメラ化A10（IgG）をペプシン消化しキメラ 化F(ab')2（Ch-F(ab')2）を作製した。キメラ化 Fab

（Ch-Fab）は大腸菌より発現させるとともに、架橋剂 SPDPによりCh-Fabのdimer（Fab dimer）を作製した。 これらを ${ }^{123} \mathrm{I} に て$ 標識しヒト膵癌細胞BxPC-3担癌ヌー ドマウスに投与、腫瘍部のイメージングをおこなった。

【結果】 ${ }^{123} \mathrm{I}-\mathrm{Ch}-\mathrm{Fab} 200 \mu \mathrm{Ci}$ を投与すると24時間後に腫 瘍部のみをイメージングできたが、 $100 \mu \mathrm{Ci}$ 投与では充 分なイメージングは得られなかった。一方、 $100 \mu \mathrm{Ci}$ の ${ }^{123} \mathrm{I}-\mathrm{Ch}-\mathrm{F}\left(\mathrm{ab} \mathrm{b}^{\prime}\right) 2$ 投与例では24時間後に腫瘍部のイメージ ングが可能であった。 $100 \mu \mathrm{Ci}$ の $^{123} \mathrm{I}-\mathrm{Fab}$ dimer投与群で は投与後 18 時間で充分なイメージングが得られ、24時 間ではCh-F(ab')2と同等の腫瘍イメージングが得られた。

【まとめ】キメラ化A10の種々のフラグメントは消化 器癌のイメージングに有用である可能性が示㖫された。
265 消化器癌におけるインフォームド・コン

セントの実際

東京医科歯科大学医学部第一外科

谷畑英一、岡部聡、新井健広、丸山祥司、李宗成、

村瀬尚哉、多田雅典、山下博典、椿昌裕、遠藤光夫

【目的】進行癌患者に合併症や副作用を起こしやすい 治療を行う場合、医師・患者間の信頼関係を損ないが ちである。そこで進行癌患者のインフォームド・コン セントの実際について、術後補助化学療法を行った進 行大腸癌患者を対象として検討した。

【方法】1992年より進行大腸癌の治瘾又は準治瘜切 除後の補助化学療法として、C D D P , 5 - F U, Leucovorin療法（PFL療法）又は $5-F U$, Leucovorin療法（FL療法）を行った。

【成績】1992年より1994年までに術後補助化学療法 を行った進行大腸癌患者は28例であった。PFL療法 では副作用として食欲不振が $92.3 \%$ 、下洞が $69.2 \%$ 、 白血球隇少が53.8\%にみられ、充分な説明と同意が必 要であった。補助化学療法のインフォームド・コンセ ントは書面にて得た。

【結論】術後早期より十分な説明と患者の同意をとる ことにより、患者の治療に対する協力が得られ、患者 自身が治療に積極的に参加するようになった。

266 胃癌切除術後再発症例に対する告知のブロ セスについて

神奈川県立がんセンター・外科第三科

西連寺 意勲, 本橋 久彦, 小林 理, 円谷 彰,

奥川 保, 利野 靖,

[目的］胃癌の終末期の経過は速く、QOLの低下も急 激であり、informed consent（IC: いわゆる告知を含む) に至る時間的、心理的ゆとりは少ない。そこで、胃癌 切除術後再発症例に対して施行している対策と告知の プロセスについて報告する。[対象と方法］胃癌切除術 後再発症例に対して、在宅IVHを施行した症例(HPN症例) 12 症例を対象とした。蔠末期の告知のプロセスは、まず、 癌との関連性を強調しない病状の説明を行い、その後 に説明を求められれば癌との関連性を説明し、さらに 余命まで話が及ぶという順序をとる。[結果]悪性の疾 患であることは初回手術時に 8割の患者は話を聞いて いる。しかし、病名に対する受け止めの出来ている患者 (ICのできた患者)は 9 人中 4 人程度である。再発時の病 状の説明は全症例受けているが、再発病状に強い不満 を漏らしている症例 (否認している症例)が12例中 3 例 ある。余命告知にいたった症例はなかったが、現在生存 中の症例を除く死亡症例9例は全例が在宅で療養を希 望した。[結論]HPNと我々の施行している告知のプロセ スは、胃癌術後再発症例に対して妥当であると考える。 
267 直渴㾇患者への㾔告知の現況と術後 Q O

L 評価

青森市民病院外科

橋爪正, 朝倉靖夫, 高橋克郎, 柴崎至, 高橋賢一, 三上勝也，小舘昭示,西沢諒一

[目的］自己決定権を尊重する立場から患者に対する 癌告知の問題は医療者にとって避けて通れない問題で ある.演者は最近，直渴富患者へ積極的な癌告知を試み ている.最近 3 年間の癌告知の現況と共に,アンケート から得た告知患者の術後QOL評価について報告する。

[結果] 告知に際して年跲, 性差, 職業,家庭環境,臨床 病期等は原則として問わないが患者の自発的な意志を 最優先した.1993〜 1995年8月迄, 癌告知は 42 例であり， 治切除の $60 \%$ 以上は告知例である.一方, 告知例を含 めた過去5年間の直渴癌術後無再発85例を対象に, アン ケート誈査 (1995年4月施行)を行った。患者を癌認識群 とそうでない群に分けると,身体的要因,精神社会的要 因のいずれも2群のQOL評価に有意差は認められなかっ た.しかし病気への不安感を訴えるものは術後観察期 間によらず告知例にやや多かった.患者の効用の面か ら,社会的要因を重視した群は60\%以上が自分の病気 を嵒と認識しており，QOL評価は比較的良好であった． 逆に,家族関係や精神的要因を重視した者の癌認識率 は30\%前後と低く日常生活の満足度もやや低かった。

268 大晹癌症例における癌の告知,準告知.非 告知別のインフォームドンセントの問題点の検討

岐皁大学第 1 外科

林勝知. 柴田雅也。千賀省始、鬼束嵉義, 広瀬一

[目的] 大渴癌症例における癌の告知,準告知,非告 知別のインフォームドコンント (IC)の問題点を検討した。[方法] 最近 14 年間の大腸癌の手術症例 217 例を対象に。癌告知 の程度の差異により以下の4群に分類し，ICの判定およ び問題点を検討した.4群は。告知群 (癌告知) 17例, 準告 知A群 (悪性の可能性がある腫檺と告知) 21 例。準告知B群 (悪性の可能性がない腫瘍と告知) 92 例, 非告知群 (癌お よび腫瘍の非告知) 87 例である.ICの判定は医師と患者 の治療上のコミュニケーションが良好の場合には同意。不良の場 合には不十分とした. [成縝・結論] (1) 年齡 : 告知群 $54.5 \pm 11.5$ 歳, 涑告知 $A$ 群 $63.5 \pm 10.7$ 歳, 準告知 B群 62.4 \pm 10.8 歳, 非告知群 $63.9 \pm 10.6$ 歳であり,告知群は他の 3 群に比し有意に年龄が低かった。性別, 結腸癌と直腸癌, 早期癌と進行癌および根治度の比率は 4群間に有意差を 認めなかった。(2)ICの同意, 不十分の比率は4群間で有 意差を認めなかった。(3) ICの問題点:告知群でCur Cの 1例に根治度の虚偽の説明を行った。病状の説明におい て, 準告知 A群で不満を1例, 対応に難啮したのを準告知 B群で 4 例。非告知群で 2 例に認めた。外マの受け入れ不良 を準告知 $A$ 群。準告知B群で各 1 例, 非告知群で 2 例認めた。
269 一般病院における癌告知の検討一患者および

家族アンケート法一

恵み野病院外科 ${ }^{11}$ 、同第二内科 ${ }^{2)}$ 、北海道大学第一外科 ${ }^{3)}$

柴田岳三 ${ }^{1}$ 、三島修1)、米山重人 ${ }^{3)}$ 、五十嵐究 ${ }^{1)}$ 、近藤博 1)、佐々木英制 ${ }^{11}$ 、柏谷朋 ${ }^{21}$ 、松井朋子 ${ }^{2)}$ 、森合哲也 ${ }^{2)}$ 、佐 藤達哉 2)、内野純一 ${ }^{3)}$

[目的]一般病院における癌告知のあり方を検討するために 入院患者およびその家族に対しアンケートを施行したうえ で、告知可能と判断された担癌症例に告知を行い、患者お よびその家族の満足度及び告知可否等を検討をした。

[方法］ 1994 年 4 月 1 日から 1995 年 1 月 31 日までに緊急入 院等を除き、当科入院患者全員とその家族に対しアンケー 卜用紙を配布し、回収した。両者の希望が一致し、我々が 可能と判断したケースに癌の告知を施行し、進行消化器癌 を中心に検討した。また死亡患者の家族に対しても意識調 查を行った。

[結果] 患者回答数は 223 例（全入院患者の $50.9 \%$ ) で、こ のうち癌患者は 65 例 $(29.1 \%)$ であった。患者家族回答数 は147例であった。癌患者65例中告知をしたのは34例 (52.3 $\%$ ）であった。非告知例では家族の反対によるものが 15 例 (48.4\%) と約半数を占めた。死亡患者家族の意識調査では 20 例中 19 例 $(95.0 \%)$ が当院での治療に満足と答え、一般 病院での癌告知が可能であることが示唆された。

270 消化器癌におけるインフォームド・コン セントー告知の実際とアンケート調査からみた問題点 富山市民病院外科

上田順彦、吉光 裕、太田長義、角谷直孝、

廣澤久史、小西一朗、泉 良平、広野禎介

[目的] 消化器癌のインフォームド・コンセントの 中で癌告知の問題点を明らかにすること。[対象と方 法] 過去 2 年 7 月間に演者が主治医の消化器癌のう ち85例を対象にアンケート結果を検討した。 [結果] (1)症例の概要：根治度A 44例、B 12例、C 29例で、 告知 56 例、非告知 29 例であった。(2)癌告知の是非： 告知をうけた生存中患者47例中、告知をうけてよか った 41 例（87\%）、よくなかった 2 例（4\%）で、告 知をうけた全家族 56 例では 46 例 $(82 \%) 、 2$ 例 $(4 \%)$ であった。(3)癌告知希望内容 : 告知患者 47 例は診断 名のみ4例、進行度 ·治療法まで 23 例、予後まで 17 例、 非告知患者 18 例は 2 例、 4 例、 1 例、全家族 85 例は 9 例、 43例、27例であった。(4)治療内容：告知例で根治度 BCでは静注化学療法や再手術施行は18例中 17 例、非 告知例では23例中 4例であった。[結論］(1)癌告知は 本人の告知に対する希望を事前アンケートで確認す心゙ きである。(2)癌告知内容は多岐に渡るため長期間治療 に当たる医師が行うべきである。(3)根治度BCで積極 的治療が必要な症例では癌告知は必要である。 
271 消化器癌患者へのインフォームドコンセ ント ーアンケート調査からー

名古屋市立大学第一外科 小林建司、橋本俊、福井拓治、増田和彦、真辺忠夫 <目的>癌患者の病名告知の是非を考える目的で告知 を行なった患者および家族にアンケートを行なった。 ＜対象および方法＞1993年7月から1994年12月まで に小林が主治医であった悪性疾患患者 28 名のうち、 病名および予想される予後を説明した患者23名に告 知の是非等について患者および家人にアンケートを送 付した。患者 23 名中 22 名、家人全員から回答を得た。 この22名中m、sm癌を除いた15名を対象にした。 く結果>(1)告知に賛同した人 14 名、告知に反対であ った人 1 名であった。(2)告知後は全員が家人とともに 立ち直ることができたと答えた。(3)再発時は、告知を 受けたくなかったと答えた 1 人を除く14名がはっきり 告げてもらいたいと答えた。家人に対するアンケート 結果は、全員が告知をしてよかったと答えたが、生命 予後まで伝えるのは反対であった人が1名いた。

〈まとめ>告知を望まない患者がいることは確かであ り、無条件に告知をすることは時期尚早であるが、患 者の大半は告知に賛成であることから本人抜きで家人 と主治医とで告知の有無を決めることは危険であり、 本人の意思表示を評価することが必要である。

\section{2 癌告知の実践と患者が望む告知方法の検討}

日本大学第 1 外科

中山壽之、天野定雄、三宅 洋、丹正勝久、

富田凉一、柴田昌彦、秋山太津男、瀧澤秀博、

藤崎 滋、根津 健、黒須康彦

【目的】手術に際して患者が望む告知方法を検討する ため、癌患者に対し病名告知とアンケート調查を行った。

【対象】本人および家族の同意が得られた消化器癌患 者 15 人を対象とした。

【方法】告知：まず家族のみに癌告知を実施。家族同意 の下、患者および家族を同席にて癌告知した。

アンケート:1) 自分の疾患の病名、病状、治療方針の告 知について、2)外科手術における告知の意義、3) 知りた い情報、4) 告知される環境の 4 項目を調查した。

【結果】 $90 \%$ 以の患者が入院中に受けた病気に関する 説明に基づき病名、病状、治療方針をほぼ理解できたと 答えた。手術を受けるためには正式な病名を知ることが 「ぜひ必要である」と答えたものは $60 \%$ ありり、告知の 下に手術を行うことが望ましいと思われた。患者が知り たい情報は病名、治る可能性だけではなく、「死との関 連性」、「治らない可能性」などの negative factor も 含まれていた。患者が望む告知環境は「家族と同席」が $60 \%$ 、「自分だけ」が $40 \%$ あった。今後は患者の自己決 定権を尊重した癌告知が必要と考えられた。
のインフォームド・コンセントの実祭

聖マリアンナ医科大学横浜市西部病院外科 ${ }^{11}$

同東横病院外科 ${ }^{21}$ 、同第一外科 ${ }^{31}$

萩原 優、小森山広幸、田中一郎、前田長生、関

陽彦 ${ }^{11} 、$ 山村卓也 ${ }^{21}$ 、山口 晋31

[目的］本邦における消化器癌のインフォームド・ コンセント（以下 I C ) は、正式な病名を患者自身に 知らせるか否かが根本的な重要な問題である。

そこで、われわれは外科病棟に入院時に任意のアン ケート調查を行い、I Cの隆して躁床に役立たせてい るのでその結果と問題点について埌告する。

[方法並びに対象］外科病棟に入院した患者全例を 刘象として、18 項目からなる質問をした。

[結果] 回答は 340 例で、消化器癌は 114 例で あった。70\%の人が痹であっても正式な病名を知り たいと、61\%の人が例え予後が悪くても知りたいと 回答した。実察の告知は完全告知 36 例 $32 \%$ 、暖昧 告知 24 例 $21 \%$ 、告知せず 51 例 $45 \%$ であった。

[考案並びに結語] 約 $70 \%$ 人が正式な病名を知 りたいと望んでいるが、実際には $32 \%$ 人に告知し ているに過ぎない。もっと本人の意思を尊重する必要 がある。また、約 $8 \%$ 存在する知りたくない人は分か るし、病名告知に大いに参考となる。

274

消化器癌におけるインフォームドコンセン トのあり方について一在宅ホスピスケアからの提言一 福島労災病院 外科

嘘野吉和, 武藤淳, 菅野明弘, 森山厚,

伊藤公志, 平賀雅樹

進行癌患者に対するインフォームドコンセントが行 われない最大の理由は、癌が治らないと判明した時点 でその後の対応の仕方を医師が知らないからである。 しかし、治らない患者に対する医療（ターミナルケア） を積極的に行ってみると、治療開始初期から真実を伝 え、患者の人生観を考虑に入れながら治療を行うこと が重要であることを痛感する。そこで今回報告する内 容は、第 1 に当科で1992年から開始した「がん告知」 の現況、第 2 は進行消化器癌患者に対する抗癌剤治療 におけるインフォームドコンセントの現況、第 3 は夕 一ミナルケア、特に1987年から取り組んでいる「在宅 ホスピスケア」の現況などである。なお、がん告知は 患者本人に告知希望の有無を確認した上で行っている が、これまでの消化器癌患者への癌告知率（．癌と説 明）は14\%('91年), $31 \%$ (' 92 年). $66 \%$ ('93年), $90 \%$ (' 94年)と、'94年にやっと患者の告知希望率に達してい る。また、在宅ホスピスケアの症例はこれまでに110例

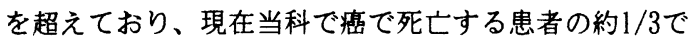
その大半が自宅で亡くなっている。 

インフォームドコンセント (IC) の実際

日本大学第 3 外科

藤井雅志

准行再発癌に化学療法を施行する場合は、基本的に 臨床治験における GCP に準拠して IC が取られる。ま た、可能なかきり本人から文書での承諾書を得ること を原則としている。しかしながら、1. 正確な情報を患 者に伝えるには病名告知は必須であるが、予後告知は 困難である。2.化学療法そのものの効果が充分でない。 3. IC に要する時間的制約が大きい。4. 化学療法施行後 も follow up を要するが、時間的制約、病床確保の困難 性などにより、未告知例は、実際上臨床治験への参加 は困難である。一方、充分な IC が得られた症例では、 1. 治療に積極的になる。2. 副作用対策が早期に開始で きる。3.ICを行うことで、医師側の効果や副作用に対 する意識の向上が見られるなどの利点がある。対策と して1. 予後告知は腫晹マーカー值を本人に知らせるこ とで病状の進行を理解させやすい。2. QOL Score 表を 持たせる。3.やがて来る終末期医療についての説明を 少しずつ分けて長期に行うなどが行われているが、充 分な ICを得るには何より時間的余裕が必要で、医師 一人が受け持てる患者数には自ら制約があり、多くの 臨床腫場医の育成が必要である。

九州大学第 2 外科

西崎 隆、竹中賢治、矢永勝彦、島田光生、調 憲、 祇園智信、藤原 雄、副島雄二、内山秀昭、杉町圭蔵 【目的】肝細胞癌症例の大部分は肝硬変合併例であり 肝機能障害の程度は治療方針選护の重要な鍵となる。 過去 2 年間の切除可能例90例に対するインフォームド . コンセントの現状を報告する。【方法】画像診断によ り癌の存在範囲を決定し、肝機能障害と静脈瘤の評価 を終えて説明を行う。肝癌が画像上強く疑われること を本人に告げる。治療法の選択肢として肝切除、リピ オドリゼーション、TAE、PEIT、マイクロ波凝固療法 がありそれぞれの長所短所を説明する。肝切除の長所 は癌を取り除く効果が大きく、再発が他の治療法に比 べ少ないこと短所は侵寣が最も大きく、社会復帰まで に時間を要することを告げる。【結果】1) 手術療法 を拒否して、他の治療法を選択した症例は $1.1 \%$ （1/90 例）であった。2）患者の治療選択を尊重した説明を 行い、治療に協力を得ることができた。3）合併症が 生じた場合にも泝訟など患者とのトラブルはなかった。 4) 再発例にも良好な医師患者関係を保ちながら再発 の治療をしえた。【結語】術後followと再発後の治療 に関する術前の十分な説明が術後、良好な医師患者関 係維持のために重要と考えられた。
277 HVI・CHP肝灌流化学療法による肝癌治 療例におけるInformed consentの現状と問題点 神戸大学第一外科

具 英成、富永正寛、岩崎 武、前田一郎、楠 信也、 村松三四郎、杉本武巳、黑田嘉和、斎藤洋一

【目的】肝静脈分離 - 活性炭吸着(HIV · CHP)経皮的肝 灌流化学療法を用いた進行肝癌治療におけるInformed consent(IC)の実際と問題点を検討した。【方法】複数 の肝内病変を有し肝切除、TAEなど既存の治療法で効 果が期待し難い進行肝癌42例を対象とした。最初に家 族代表者に病名及び原疾患の状況を説明し患者へのIC の希望の有無を確認した。希望した場合には本人及び 家族に、希望しなかった場合には家族のみに方法、副 作用と合併症、治療成績を説明した。同意は定式化し た書面にて説明後 1 週間以内に確認した。【結果】告 知を希望した家族は7例に留まり、うち3例では進行癌 の告知は希望しなかった。家族の意向に反して病名告 知を強く希望した患者は2例あり本人のICを得た上で 治療した。家族が本人へのICを希望しなかった理由は 「癌告知そのものを望まない」が30例、「患者の気弱 さ」17例、「告知後の生活や心理的状況の变化を望ま ぬ」10例の順であった。【結語】進行肝癌を治療対象 とする性格上、患者本人のICを本療法実施の前提条件 とすることは現状では不適当と考えられた。 「告知の上のターミナルケア」実践の糸口と なった 2 定例 P L 病院外科

中尾照选、富室哲也、所忠男、喜多岡雅典、松並展瀜 [症例 1] 51 藏、男性、宗数家。平成 5 年 1 月に胃

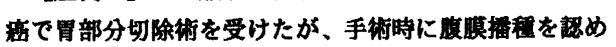
た。術後 13 日目に妻より房名・通行度の告知を受けた。

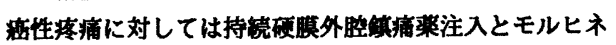
馀放錠でコントロールした。平成 6 年 9 月に永眠。告知 を受けた後、パソコン通信で同湶に向けて閏病日記を発

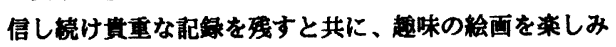
ながら家旋や多くの友人に囲まれて死を迎えた。

[庭例2] 49 歲、男性、自営業。平成 3 年 2 月に他 県で直捣榬に対して低位前方切除街を受けた。その後、 局所再発による疼痛のため、平成 5 年 8 月に当科を受診。 本人の希望に添い病名・予後を告知した上で槽行絬渴に 人工服門を造設した。疼痛に対してはNSAＩＤとモル ヒネ徐放浣でントロールした。平成 6 年 10 月に肺転 䅗により永眠。告知を受けてからも、旅行や睹事なと気 ままな生活を続け家族を困らせた。

[結褊] 同時期に、性格の対照的な二人の末期稳患者 に病名と予後を告知した上でターミナルケアを行うとい う経镜をした。以来、本人が希望するなら可能な限り真 夷を知らせた上で治港にあたる努力を綂けている。 
279 大腸癌における锯鎖抗原の新たな観点よ

\section{り見た臨床的価値についての検讨}

千葉大学第一外科

知久 媇、斎藤典男、布村正夫、幸田圭史、滝口伸浩

早田浩明、尾崎和義、兽谷芳樹、鈴木弘文、近藤英介 若月一雄、石川文彦、古川留魅子、安富 淳

吉村光太郎、更科広実、中島伸之

[目的］大䭪癌における禟錤抗原SLX、STN、CA199の発現特性をふまえ、新しい診断および治康への応 用につき考察した。[方法] 149例の大腸癌切除骤本 に対しSLX、STN、CA19-9の組織発現を免疫染色で 評価し、別の 121 例に対し術前血涪中SLX、STN、 CA19-9、CEA值を測定し検时を加えた。[結果］血 清中CEA值はDukes分類すべての病期で陽性率が最も 高く、睡滛量を最も鋭敏に反映するマーカーであっ た。SLX、CA19-9については、血滦値がDukesC、D 例で陽性率が高く庭枟移の存在を示唆しうると考えら

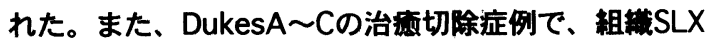
高発現群は異時性肝枟移発現の高リスク群であった。 STNに関しては血中の陽性率が低く、組樴での陽性率 が高いことよりimmunoscintigraphyを用いた大腸痘 の局在診断に応用可能で、実際我々は抗STN抗体を用 い大腸癌の骨盤内再発を描出し得た。現在immunotargeting therapyの可能性につき検討中である。

280 胃癌の腫瘍マーカーとしてのシアリル-Tn抗 原の有用性

九州大学第二外科、国立九州ガンセンター 市吉裕二、友田政昭、富崎真一、大野真司、

馬場秀夫 ${ }^{1}$ 、友田博次 ${ }^{1} 、$ 杉町圭蔵

【目的と方法】胃癌患者における血清中のシアリル-Tn 抗原(以下STN)の腫瘍マーカーとしての有用性を評価 するため、胃癌切除例350例について、術前の血清STN 值と他の臨床病理学的因子やCEA値ならびに予後との 関係を retrospectiveに解析するとともに、外来フォロー 中再発した12例について、術後のSTN值およびCEA值 の推移を検討した。【結果】(1)術前の血清STNが陽性 (cut-off值 45U/ml)であったのは46例(13.2\%)であった。 それらは低值群304例と比較して、腫瘍径が大きく、ま た漿膜浸潤、脈管侵襲、リンパ節転移、肝転移の陽性 率が高く、予後も不良であった。血清STN值とCEA值 を組み合わせた解析では両方が陽性であった15例は片 方のみ陽性であった症例より有意に予後不良であった。 外来にて血清STN値をフォロー中に再発を確認した 12 例のうち術前血清STN值が高值であったのは4例あり、 いずれも再発の臨床所見に先だって血清STN值の上昇 を認めた。【まとめ】血清STN值は胃癌の予後規定因 子となるとともに、再発予知の有力な腫瘍マーカーと なることが示唆された。
281 進行消化器癌治療におけるQOLの重要性

とその因子に関する検討

国立病院九州がんセンター・消化器部外科,

松岡秀夫, 瀬尾洋介, 城間伸雄, 兼城衛, 足立英輔,

馬場秀夫, 鸿江俊治, 斎藤貴生, 友田博次

【目的】進行または再発消化器癌治療において、QOL の確保は重要な課題の一つである。今回、免疫併用療 法中のQOLに関し検討すると同時に、QOL向上の指標 となる客観的因子について検討した。【対象と方法】 進行再発消化器癌30例に対し免疫化学併用療法を行い、 2 週間毎のQOL調査と同時に、血中のホルモン、サイト カイン、flowcytometry解析による免疫能を比較検討した。

【結果と考察】治療によりQOLの改善した症例は $27 \%$ (7 ／26）であった。治療開始後10日目のkillerT／ suppressor T の治療前値に対する比と、生存期間は正の 相関を示した。QOLの満足度と血中ホルモンとの相関 は得れなかったが、IL-6、G-CSFの低下とは、高い一致 率（IL-6, 93.0\%：G-CSF, 90.7\%）と相関性（相関係数： IL-6, 0.336：G-CSF, 0.637）が得れた。また、G-CSF、 IL-6の低下と、helper inducer $\mathrm{T}$ の投与前後比とは相関 した。以上より、QOLの向上と、免疫能の上昇、生存 期間の延長とは互いに密接な関係があり、その客観的 指標として、免疫能や、G-CSF、IL-6の変動をみること は重要と考えられた。

282

の意義

横兵市立大学第一外科" ${ }^{1}$ 、神奈川県立かんセンター外 科第三科 ${ }^{2}$

利野 蜻11、高橋 諴 ${ }^{11}$ 、竹舅敏孝 ${ }^{11}$ 、鈴木 諴 ${ }^{1}$ 、 塩沢 学" ${ }^{11}$ 、分部 敏 ${ }^{11}$ 、陳 超 ${ }^{11}$ 、山本裕司 ${ }^{11}$ 、今 田敏夫 1)、天野富薰 ${ }^{1}$ 、松本昭彦 ${ }^{11} 、 小$ 林 理 $^{21}$ 、西

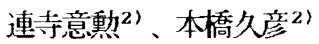

[目的] 胃癌症例で進行度、予後と内分泌系の異常 とについて榙討した。[吱象] Stage I少よじstage IVの胃癌症例で各々 26 例、1 4 例、再発胃癌患者5 例定対象とした。[万法] Thyrotropin-releasing ho rmone ( $T R H$ ) テストをし、血中の成長ホルモン

(GH) 、甲状腺刺激ホルモン（TSH）在測定した Collu らの判定基淮によりGHが前值の2 倍以上、5 $\mathrm{ng} / \mathrm{m} \mid$ 以上の上昇したものをparadoxical response

(PR)とした。また胃癌再発患者の成長ホルモンを 経時的に測定した。[結果] TRH負荷後にStage I、 Stage IVの両群間でTSH、GHは有意差はなかっん が、PR陽性の頻度はStage IVの)症例で有意に高かっ た $(p<0.05)$ 。Stage IV症例でPRが陽性例は陰性例 より有意に生存率の低下がみられた（ $0<0.01 ） 。$ 再発

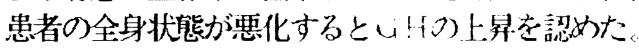

[考察] GHの反応はStage; 予後の推定に有用で方る 

覀性腫瘍に伴う高 $\mathrm{Ca}$ 血症の原因物質として発見され て以来、多くの正常細胞や癌に発現が認められ、腫瘍 の増殖や転移との関連が注目されている。今回は朠癌 におけるPTHrPの発現と意義について検討した。

【対象と方法】䐙癌切除症例 22 例を対象とし、抗 PTHrP抗体を用いて ABC法にて免疫組織化学染色を 行った。【結果】PTHrPの発現は16例(72.8\%)に認め られた。stage別ではstage III以上で陽性率が高かった が、PTHrP陽性群と陰性群とで生存率に有意な差は認 めなかった。組織型、脈管侵襲、リンパ節転移との間 には相関は認めなかった。蒌後面への浸潤はRp(+)で は81.4\%に認められ、また、肝転移例における発現率 は $80.0 \%$ と高值であった。

【結語】PTHrPは苹癌の腫瘍マーカーとして有用であ り、苹後方浸潤あるいは肝転移の予測因子となり得る 可能性が示唆された。

\section{4 食道扁平上皮癌における腫瘍マーカーと}

してのCYFRA21-1の臨床的有用性

東京医科歯科大学第一外科

吉田達也、吉野邦英、河野辰幸、永井 鑑、 井上晴洋、矢野謙一、長浜雄志、堀 光、

M.アッサダー、遠藤光夫

【目的】CYFRA21-1をSCCと対比して、食道扁平上 皮癌の腫瘍マーカーとしての有用性を検討した。

【対象】1994年11月〜 1995年7月の当教室の食道扁 平上皮癌未治療症例全52例で男性41例・女性 11 例。

【結果】治療前陽性は、CYFRA21-1（基準値 $3.5 \mathrm{ng} / \mathrm{ml}$ 以下) は35例中8例(22.9\%)で、SCC（基準値 $1.5 \mathrm{ng} / \mathrm{ml}$ 以下) は35例中9例(25.7\%)、どちらかが陽性 は35例中15例(42.9\%)。両者の相関係数は0.03。術前 末治療手術症例のstage別の術前值は、stage 0 / Iでは 両者ともに全例陰性、stage III ではCYFRA21-1は5例 中1例(20.0\%)、SCCは5例中2例(40.0\%1)で陽性、stage IVではCYFRA21-1は8例中4例(50.0\%)、SCCは6例中4 例(66.7\%)で陽性。術後再発・転移判明7症例でそれぞ れの反応をみると、CYFRA21-1では5例(71.4\%)が異常 值に対し、SCCは4例(57.1\%)で異常値。

【結語】CYFRA21-1とSCCは食道扁平上皮癌におい て相補的な意味を持ち、またCYFRA21-1は再発・転移 の指標として有用であると思われた。

285 食道癌における腫瘍関連抗原シフラ(CYFRA 21-1)の臨床への寄与

東京女子医科大学消化器外科

中村 努, 井手博子, 江口礼紀, 太田正穂,

谷川啓司, 菊池哲也, 羽生富士夫, 高崎 健

[目的］われわれは食道癌患者において新しい腫瘍 関連抗原シフラ(Cytokeratin 19 fragment) を测定し、 その臨床的有用性を検討したので報告する。

[対象] 当科における食道癌患者 58 例において测 定した。その内訳は食道癌切除例 32 例、内視鏡的粘 膜切除例 6 例、非切除再発例 20 例であった。

[方法］シフラはRIA 法にて测定しカットオフ值を 2. 0ng/ml とした。SCC, CEA, CA19-9のカットオフ值は $\mathrm{SCC}: 1.5 \mathrm{ng} / \mathrm{ml}, \mathrm{CEA}: 5 \mathrm{ng} / \mathrm{ml}, \mathrm{CA} 19-9: 37 \mathrm{U} / \mathrm{ml}$ とした。

[結果] 食道癌切除例 32 例の陽性率はシフラ 40.6 \%, SCC:25\%, CEA:12.5\%, CA19-9:3.1\%とシフラが最も 高かった。 stage との関係では、シフラはstage3以上 の症例のみで陽珄であった。内視鏡的粘膜切除例 6 例 ではいずれの腫煌マーカーとも異常を示さなかった。 非切除例・再発例 20 例での陽性率はシフラ:75\%, SCC:50\%, CEA:15\%, CA19-9:15\%であった。

[結語］食道癌においてシフラは肺癌ほどの高い陽 性率は示さなかったが、ルーチンに测定すべき新しい 腫瘍マーカーであると考えられた。

286 膵疾患におけるサイトケラチン19フラグメ ント、c-erbB - 2 および CA 19-9 発現の臨床的意義 について

京都大学第一外科 ${ }^{1)}$, 同核医学科 ${ }^{2)}$

大塩学而 ${ }^{1}$, 岡田憲幸, 今村卓司, 諏訪裕文,

吉富彰一, 田中俊郎, 王 兆輝, 細谷 亮,

阪原晴海 ${ }^{2)}$, 今村正之 ${ }^{1)}$

【目的】細胞内骨格蛋白であるサイトケラチン19フラ グメント、および c - erbB-2 発現の臨床的意義を CA 19-9 と比較検討した。【方法】血清中濃度は、 radioimmunoassay あるいは enzy meimmunoassay で測定し た。組織での発現は免疫組織染色により検討した。

【結果】血清值：サイトケラチン19は、膵癌患者では 56\%(51/91例) が陽性であった。慢性膵炎13例では陽 性例を認めなかった。膵癌では、転移例で陽性率が高 く、生存期間も有意に短かった。c-erbB-2 は、膵癌 では34\%(37/109) が陽性であった。慢性膵炎では、 20\% (2/10) が陽性であった。膵癌では、転移例で陽 性率は高値であり、生存期間も短かった。CA 19-9は、 萃癌で81\% (85/105) が陽性で、慢性膵炎では $18 \%$

(3/17) が陽性であった。免疫組織染色：膵癌では、 サイトケラチンは $67 \%(50 / 75) 、 c-e r b B-2$ は $28 \%$ (8/29)、CA19-9は、91\%(68/75) が陽性であっ た。組織の染色性と血清值の相関では、CA19-9およ びc-erbB-2では正の相関を認めたが、サイトケラチ ンでは有意の相関関係を認めなかった。【結語】サイ トケラチン19フラグメントおよび c-erbB - 2 蛋白は、 膵癌患者で上昇しており、鑑別診断、進行度、予後の 指標となる。 
287 Cytokeratin 19 fragmentsを認識する monoclonal抗体CYFRA21-1による胃癌の血清診断と予 後との関連

大阪市立大学第 1 外科

仲田文造、鄭 容錫、加藤保之、小川正文、小川佳成、 乾 嗣昌、前田 清、澤田鉄二、曾和融生

[目的] CYFRA21-1はcytokeratin 19を特異的に認識 するmonoclonal抗体である。今回、胃癌における血清 CYFRA21-1值の測定意義を予後との関連から検討した。 [方法] 胃癌初発101例、再発9例の血清CYFRA21-1を 測定し、臨床病理学的因子・予後との関連を検討した。 [結果］CYFRA21-1について有意差を認めたものは腹 膜播種、肝転移、およびリンパ節転移であった。生存

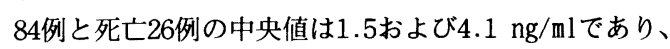
有意差を認めた。また、cut-off值を $5 \mathrm{ng} / \mathrm{ml}$ とすると、 この值以上の12例は以下の98例に比へ有意に予後不良 であった。Cox hazards modelを用いた解析で、 CYFRA21-1は独立で有意な予後因子であった。

[結論] 臨床病理学的因子とCYFRA21-1值の検討から、 cytokeratin 19は胃癌細胞の壊死に伴い血中に流出す ると思われ、極めて進行した状態を示し、切除不能例 や再発のモニタリングに有用と考えられた。また、胃 癌における血清CYFRA21-1值は予後因子として有用で あることが示された。

288 胃癌の新しい畽瘍マーカー

Matrix Metalloproteinase 9 の測定とその意義 愛知県がんセンター消化器外科、 富士菌品工業(株)バイオ医薬部*

鳥井彰人、小寺泰弘、上坂克彦、平井孝、安井健三、 森本㣚史、山村義孝、加藤知行、紀藤毅、藤本昇 * (共同研究者：愛知学院大学菌学部生化学、早川太郎) [目的］癌の浸潤や転移において重要な役割を果たして いると言われる Matrix Metalloproteinase 9(MMP-9, $92 \mathrm{kDa}$ gelatinase/type IV collagenase, gelatinase B)の血槳中の浱度 を测定し、その意義について検討した. [対象と方法] 健常者138名および当科で胃切除が施行された胃莓患者 70名の血槳中MMP-9浱度を測定した。测定にはOne-step sandwich enzyme immunoassay(富士薬品工業)を用いた.

[結果] 胃㾔患者 $80.8 \pm 53.4($ mean $\pm S D$ ng/ml)、健常者 $36.3 \pm 13.2$ と胃癌患者で有意に高値を示した. 陽性率で は健常者で $3.6 \%$ であるのに対し胃癌患者では $56 \%$ \%゙あっ た. 術前・術後の比較でMMP-9值は術後有意に低下した。 腫瑒径 $6 \mathrm{~cm}$ 以上の症例の術前MMP-9值は腫瘍径 $6 \mathrm{~cm}$ 未满 の症例より有意に高值であり、リンパ腺転移を伴う症例 は、伴わない症例に比して有意に高值を示した. 胃瘦の 深達度が梁くなるにつれて術前MMP-9值は上昇し、総合 的進行程度の進行に伴って高値を示した。 [結語] MMP-9は胃㿋の腫瘍マーカーとして有用と思われた。
289 CEA Doubling time による消化器癌の

生物学的特性と再発後生存期間の分析 福岡市民病院外科

是永大輔、折田博之、前川宗一郎、佐伯浩司、 馬渡恭太郎、矢野和浩、山賀博彦、板阪英俊、 武藤庸一、池田俊彦

【目的】CEA Doubling time (DT) の面から腫瘍の生物 学的特性と再発後生存期間を分析した。【方法】過去 6 年間に血中CEA值が経時的に測定され、かつ持続的 高值を呈した再発癌37例（胃癌20例、大腸癌17例）を 対象とした。CEA DTはStaabらの方法に準じて片对数 グラフの回帰直線から算定した。【結果】DTは胃癌; $229 \pm 100$ 日、大腸癌; $85 \pm 15$ 日であった。年齢、腫瘍 径、肉眼型、組織型では大差なかったが、女性や $\mathrm{S}$ 期 高率群 $(\geqq 15 \%)$ のDTは男性や低率群 $(<15 \%)$ 比して 有意に低かった $(\mathrm{P}<0.05)$ 。治癒切除後に再発した22例 (根治A，B)についてみると、DT $<40$ 日の場合の平均生 存期間は 150 日、40日 D DT<126日では398日、DT $\leqq$ 126日では644日であり、DTによって再発後生存期間 の子測が可能であった。DTと再発後生存期間には明か な正の相関があり $(\mathrm{P}<0.05)$ 、仮にDTが同じでも大腸癌 の生存期間は胃癌よりも長いことが証明された。 【結語】CEA DT は腫瘍の発育速度を反映し、再発後 生存期間を予測するうえで有用な指標と考えられた。

290 清学似衫断への兔川

Ifll 清Heparitinaseによる遠隔枟移の血

日本医科大学附属第二病院消化器病センター"),

日术矤科大学附属多㻺永山病院病理部 ${ }^{21}$, 協同乳業 基礎研究沂 ${ }^{3)}$, 日本医科大学老人病研究所 ${ }^{4}$

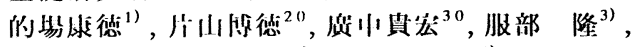

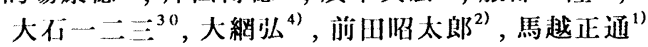
【日的】我々は癌枟移に抢ける腫場細胞の血管基 底榄通過段陆に発現するHeparan sulfate proteoglycan分解酸素：Heparitinase (HSase)が癌 の浸洞枟移に密接な䋆係を有することを塟告してき た. 今回思者仙清小のHSaseを测定し，枟移診断を 陚みた。【方法】消化器癌患者遠隔転移陽性(A群) 10 例, 陰性 (B碓)48例. 消化器良性疾患患者 (C群) 27 例. 各雔のIlli清HSaseをモノクロナール抗HSase抗 体を用いBIOcoreバイオセンサーで測定した.【結 果】A㭌 $272.1 \pm 133.2$ resonance unit (1000 resonance units $=1 \mathrm{ng}$, mean $\pm S D)$, B噒 $129.4 \pm$

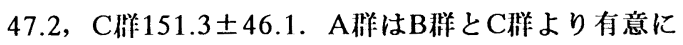
高かった $(\mathrm{P}=0.002) .200$ resonance unitsをカット オフ值とした場合, 邀隔枟移陽性の感度は80.0\%, 特異性は $83.3 \%$ ，正確佼は66.7\%。䧗膜転移のみの 瘷例は136.2 25.2でA棑より優位に低かった $(\mathrm{P}=0.019)$.【結論】缃清HSaseは遠隔転移症例で 優位に高く，莿移マーカーとして臣床応用が可能と 考えられた。 
SiarylLe'の娭討

神戸大学第一外科、问保健 ${ }^{*}$

池川隆一郎、中江. 朗、中村毅、吉岡应、宮村 一雄、川崎健太郎、成明晃一、鈴木知志、岩谷慶照、 榊原孝至、多淵芳樹 、斎藤洋一

【目的】力腸癌におい一、増殖活性、接着因子の発 現を組織学的に評洒!、卡机らの意義と両者の関連を 検討した。【対象・广法】大腸癌62例を対象とし、 AgNORスコアを測定し、接着因子としてCD44v6抗体 およびSLX抗体を用いて免疫組織染色を行い、その発 現を検索した。【結果】大腸癌のAgNORスコアの平 均は3.83 土0.29であ.た深達度 $\mathrm{ss}$ 以上の平均は、 $\mathrm{mp}$ 以下より有意に高く、肝転移陽性、腹膜転移陽性、リ ンパ節転移陽性の平圴は有意に高かった $(\mathrm{p}<0.05)$ 。 中間値3.86ご2群に分けると、高AgNOR群は、低 AgNOR群に比べて有意に予後不良であった（p<0.05）。 大腸癌に゙おりるCD44v6、SLXの発現率はそれぞれ $45.2 \% 、 40.3 \%$ あ゙た CD44v6、SLXともに肝転移 陽性例の発現率は陰性より高い傾问を示した。 CD44v6、SLXともに:陽性例と陰性例の平均AgNORス コアに差は認めなかりた【【結語】CD44v6および SLXは転移能の指標として、AgNORで評価される増 殖能とは独立した指標となる可能性が示唆さ机た。

292 脺癌原発巣および転移巣におけるlaminin 発現と臨床病理学的因子の関係

島根医科大学第一外科 平原典幸, 仁尾義則, 武田啓志, 大森浩志, 佐藤仁俊, 三成善光, 角 昭一郎, 田村勝洋 (目的) laminin(以下LN)は基底膜を構成する糖蛋白 であり, 癌の浸潤.転移との関係が注目されている。 今回, 我々は脺癌原発巣および転移巣におけるLNの 発現意義を検討した。（方法）膵癌原発巣49例, 転移 例23例を対象として，抗LN抗体を用いてSAB法によ る免疫組織染色を行い, 各種臨床病理学的因子との関 連を検討した。(結果) (1)原発巣49例中19例, 転移巣 23例中7例の基底膜LNが染色された。(2)T因子別での 陽性率は，T1b,71.2\%; T2,44.4\%; T3,30.3\%であり，腫 瘍徍亡浸潤の増加に伴い, LN 発現性の低下を認めた。 (3)リンパ節転移は, $\mathrm{LN}(+) 19$ 例中 12 例 $(63.2 \%)$, LN(-)30例中 23 例 $(76.7 \%)$ に認め, LN(+)例ではリンパ 節転移が低率であった。(4)平均生存期間は $\mathrm{LN}(+)$ 例で 9.3力月, (-)例で12.7力月であり, (+)例で予後不良の 傾向を認めた。（結語）膵癌におけるLN発現と浸潤. 転移との密接な関連が示唆され，(+)例はT因子，N因 子とも小さかったが, 実際の平均生存期間はLN(-)例 の方が長期間であり, 今後, LN以外の諸因子との相 互関係を検討する予定である。
293 大腸癌患者における血清 CD44 值測定の臨床的

意義について

千葉大学医学部第 1 外科 1)，同第 1 病理 2)

菅谷芳樹 1), 張ヶ谷健一 21, 若月一雄 11, 知久毅 1), 近藤英介11, 鈴木弘 文 1)，幸田圭史 1)，布村正夫 1)，斎藤典男 1)，更科広実 1)，三方淳男 2)， 中島伸之 1)

【目的】これまで我々はCD44接着分子と大腸癌の浸潤・転移との関係を 報告してきた。CD44接着分子は細胞膜貫通性のリセプター様糖蛋白であ るが、一部のものは soluble form CD44 ( sCD44)として血清中に存在して いる。そこで大腸癌患者血清中におけるSCD44 を測定してその動態を検 索し従来の腫瘍マーカーであるCEA との相関も検討した。【方法】大腸癌 患者 35 例 (含同時性肝転移 7例)，正常対照｜群 (非炎症群)13 例，正常対 照 II 群 (良性炎症疾患群)12 例より血清を採取しsCD44 std. ELISA Kit (Bender Med Systems 社製) を用いて血清中の sCD44 H 值を測定した。 同時に血清 CEA 值も測定した。【結果】血清 $\mathrm{sCD} 44 \mathrm{H}$ 值は大腸癌患者 では1.624 $\pm 0.421 \mathrm{ng} / \mathrm{ml}$ (平均 $\pm S D$ ) であり、正常対照 | 群(非炎症群)の $0.997 \pm 0.385$ と比較して有意に高值を示したが、正常対照 1 群 ( 良性炎 症疾患群 )では $1.771 \pm 0.2$ と逆に担癌患者より高値を示す傾向が認められ た。Dukes A・B・C・D 間に有意差は認められなかったが、術後の血清 SCD44 H値は術前と比較し有意に低下を示した。同時に測定した血清 CEA 值とsCD44H 值との間には有意な相関は認められなかった。【結論】 大腸癌患者の血清 SCD44 H 值は正常対照 I 群 (非炎症群) と比較し有意に 高値を示しかつ治療に反応して有意な低下を認めた。一方良性炎症疾患 群においては担癌患者を上回る傾向を示し、今後の検討が必要と考えられ た。以上より血清 SCD44 H 值は大腸癌の治癔効果の判定に有用であると 考えられ、CEA とは独立した腫湢マーカーであることが示崚された。

294 R B 遺伝子蛋白の発現からみた胃癌の

予後との相関について

大阪市立大学第一外科

小川正文, 前田 清, 鄭 容錫, 小野田尚佳,

康 純明, 仲田文造, 加藤保之, 兽和融生

[目的]胃癌原発巣における R B 遺伝子蛋白の発現とそ の臨床的意義について検討した。

[対象と方法]胃癌94例の切除標本に対し, 抗RB遺伝 子蛋白モノクロナール抗体を用い, 免疫組織化学染色 を行った。

[結果]RB遺伝子蛋白は癌細胞の核に発現し， $51.1 \%(48 / 94) に$ 発現がみられた。RB蛋白の発現率は 壁浸潤がすすむにつれて低くなる傾向がみられ, 獎膜 浸潤陰性例では獎膜浸潤陽性例に比べてRB遺伝子蛋 白の発現率は有意に高かった $(p<0.05)$. リンパ節転移 陽性例, 肝転移陽性例では転移陰性例に比べてRB遺 伝子蛋白の発現率は低い傾向がみられた。また，RB 遗伝子蛋白陰性例では発現陽性例と比べて有意に腹膜 転移が高率にみられた $(\mathrm{p}<0.05)$. 治瘱切除例 79例の再

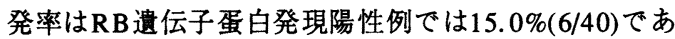
ったが，発現陰性例では35.9\%(14/39) と発現陽性例よ りも有意に再発率が高値を示した $(\mathrm{p}<0.05)$.

[結論]胃癌原発巣において癌抑制遺伝子 R B 遺伝子蛋 白の発現を検討することは予後を予測するうえで有用 である可能性が示唆された。 
消化器癌における血清HGF (hepatocyte growth factor) 濃度の上昇とその意義

東京都立駒込病院外科

谷口忠明、北村正次、戸井雅和、山本豊、荒井邦佳、

岩崎善毅、高橋慶一、森武生、冨永健

[目的] HGF(hepatocyte growth factor)は細胞増殖制御、 細胞運動の促進及び血管新生作用など、多様な生物活 性を有する。今回、消化器癌患者血清中HGF濃度を測 定し、その意義について考察した。

[対象と方法] 対象は原発胃癌104例、再発胃癌14例、 および再発大腸癌20例とした。血清HGF濃度はELISA 法を用いて測定した。

[結果] 原発胃癌症例では104例中36例(34.6\%)に、再 発例では 15 例中 14 例 $(93.3 \%)$ に血清HGF濃度の上昇が 認められた。再発胃癌症例の平均血清中HGF濃度は原 発例に比べ有意に高かった $(\mathrm{p}<0.0003)$ 。原発胃癌にお いて、stageの進行および血管侵嫯(v) と血清中HGF濃度 との間に相関関係を認め、tumor progression と血清 HGF濃度上昇の間に密接な関連性があると考えられた。 血清中CA19-9濃度および血清中CA125濃度とも相関を 認めた。大腸癌症例においても異常高值例が認められ た。

[結語] 血清中HGF濃度の異常高値は消化器癌の増殖 · 転移に密接に関連していると考えられた。

胃癌腹膜播種及び肝転移に関与する接着分 子の検討. 名古屋大学第二外科 : 中塩達明、秋山清次、 笠井保志、伊藤勝基、関口宏之、藤原道隆、高木弘。 愛知県がんセンター : 成田達彦、神奈木玲児。

(目的)癌の転移形式と接着分子発現様式を検討した。 （対象・方法）ヒ卜胃癌細胞株を用い、癌細胞におけ る接着分子の発現、血管内皮細胞 (HUVEC) 腹膜中皮 細胞 (MC) 線維芽細胞 (FB) との接着性を検討した。

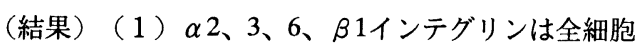
株に発現おり $\alpha 5$ はNUGC3及び4でそしかった。CD44H の発現はMKN74以外で認められ、NUGC4のみCD44V を発現していた。sialyl LewisXは2株に強く発現してい た。（2）MCへの接着性はNUGC4がMKN74よりも2 倍強く、MCをTGF $\beta$ で刺激するとECM沈着が六進し NUGC4の接着性は約2倍になった。MCへのNUGC4の 接着は抗 $\beta 1$ インテグリン抗体で約 $70 \% 、$ 抗 $\mathrm{CD} 44 \mathrm{H}$ 抗体 で約 $80 \%$ 阻止され、両抗体併用で完全に接着は阻止さ れ、ヌードマウスでも同様の結果を得たが、抗sialyl LewisX抗体、Eセレクチン抗体では阻止されなかった。 (3) MKN74はIL1 $\beta$ で刺激したHUVECへ強い接着性 を示し、抗sialyl LewisX抗体、抗Eセレクチン抗体で接 着は阻止された。(結論) 胃癌の肝転移には糖鎖-E七 レクチンを介する接着が関与し、腹膜播種にはCD44と インテグリンを介する細胞接着の関与が示唆された。
297

ドの意義

防衛医科大学校第 1 外科

冨松聡一, 市倉 隆, 上藤和彦, 向田和明, 古谷嘉隆, 小川敏也, 木村幹彦, 森田大作, 内田剛史, 玉熊正悦 【目的】ss胃癌におけるプロテアーゼカスケードの意 義を検討するために, uPA及びMMP-9の染色性と臨床病 理学的因子との関連を検討したので報告する.【対象 と方法】深達度 ss症例109例を対象に, 原発巣のパラフ イン包埋連続切片にSAB法による免疫組織染色を行い, 腫瘍細胞質の $10 \%$ 以上染色された場合それそれ陽性と判 定した.【結果】I．UPAとMMP-9の染色性; UPA, MMP -9ともに染色陽性例では H(+)が陰性例に比し高率 ( uPA: 13vs4\%,MMP-9:13vs6\%), 分化型が多い (uPA:48vs 28\%,MMP-9:51vs30\%), 肝再発が高頻度 (uPA:17vs5\%, MMP-9:23vs4\%)という特徵がみられた. II.UPA染色性 とMMP-9染色性との関連；両者の染色性には有意な相関 が見られ，組織内の染色性についても同部位が染色さ れる症例が多かった。 UPA, MMP-9いずれも染色陽性の 30例は予後不良で, 特に肝再発による死亡例が多かっ た。【結語】ss胃癌においてUPAおよびMMP-9染色陽性 例は肝転移・肝再発例に高頻度で, 両者ともに陽性の 症例は予後不良であった。以上より胃癌肝転移におけ るプロテアーゼカスケードの重要性が示唆された。

298 TGF- $\beta$ による4型スキルス胃㿋細胞の浸

潤能促進作用機序の検討

大阪市立大学第一外科

井上 透、鄭 容錫、八代正和、西村重彦、松岡 翼、

富士原知史、前田 清、澤田鉄二、兽和融生

【目的】 4 型スキルス胃癌においては、その組織学的 特徵から癌細胞の増殖・浸潤過程に線維芽細胞の関与 が推測される。我々は線維芽細胞が 4 型スキルス胃㿋 細胞の浸潤能に及は寸影翌について検討し、特にTGF$\beta$ の浸潤能促進機序について検討をした。【材料と方 法】 4 型スキルス胃癌由来細胞株OCUM-2Dおよび胃壁 由来線維芽細胞株NF-8を用いた。NF-8培養上清、TGF$\beta$ 、抗TGF- $\beta$ 中和抗体添加によるOCUM-2Dの浸潤能に ついて検討した。さらに、TGF- $\beta$ によるOCUM-2Dの浸 潤能促進機序を形態変化および接着分子発現の点から 検討した。【結果】 OCUM-2Dの漫潤能はNF-8培養上清 およびTGF- $\beta$ 添加により促進され、NF-8培養上清によ るこの作用は抗TGF- $\beta$ 中和抗体添加により抑制された。 また、TGF- $\beta$ の添加により OCUM-2Dの形態は紡錘型に 変形し、カドヘリン発現は低下した。【結論】4 型ス キルス胃癌細胞の浸潤能は線維芽細胞培養上清中の物 質により促進され、TGF- $\beta$ がこの一つであると考えら れた。このTGF- $\beta$ による浸潤能促進機序として、細胞 形態および接着分子への影頯の関与が示唆された。 

growth factor (VEGF)の発現と娷瘍先進部血管密度の 関係

日本大学第一外科 森健一郎、天野定雄、斉藤良人、滝沢秀博、 柴田昌彦、三宅洋、秋山太津男、黒須康彦 [目的]癌の生物学的悪性度の指標の一つとして注目 されている腫瘍の血管新生に着目し、血管内皮細胞の 特異的增殖因子であるvascular endothelial growth factor (VEGF) の発現と隀瘍血管密度、および臨床病理 学的因子との関係について胃癌組織を用いて検討した。 [対象と方法]教室で手術を行った進行胃癌65例を対 象とした。腫瘍の中心部及び辺縁部の10\%机り凅定、 ハラフィン包埋標本を用いてVEGF (Santa Kruz), von Willeb rand因子 (Dakopatts) の免度染色を行った。癌細胞の 細胞質が5\%以上染色されているものを陽性とし、5-50 \%の細胞が陽性を+、51-100\%が陽性をけととした。腫瘍 先進部の一定面積の血管個数を計測し血管密度とした。 [成績] VEGFの染色では、65例中35例53.8\%が陽性、 うち染色程度 (十)は34.3\%，(十t)は65.7\%であった。VEGF の染色程度と血管密度の間に正の相関が見られた $(\mathrm{P}<0$ 05)。組織型とVEGF染色程度の関係では高分化澏で有 意にVEGFのシグヤが多かった $(p<0.05)$ 。

[結論］胃癌組織内のVEGFの染色程度と隀瘍先進部の 血管密度に相関が見られた。VEGFのシ牨は高分化癌、 進んた深達度、n因子陽性、v因子陽性例で多い頓向が あった。 発現からみた間葉系細胞の段割 慶應義熱大学外科、同病理 ${ }^{*}$ 、東海大学地域保健 ${ }^{* *}$ 桜井嘉彦、大谷吉秀、五十嵐直喜、石川秀樹、龟山

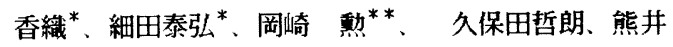
浩一郎、北島政樹

【目的】胃癌の浸潤・転移過程でのMMP-1発現に関す る癌細胞と間筫細胞の相互作用を解明する目的で分子 生物学的手法を用い、今回の㛟討を行った。【方法】 ヌードマウスの皮下に移植したヒト胃癌株5種、ヒト胃 癌株2種とヒ卜胃壁由来線維芽細胞をco-cultureしたもの を用い、それぞれ兔疫組織染色 (間接法) でMMP-1蛋 白発現様式を検討した。【結果および考察】1ヌヌード マウス可移植性ヒト胃癌株を用いた検討では、腫瘍細 胞と間質細胞ともにMMP-1蛋白発現を認め、株の種類 により、その発現様式が異なっていた。(2)ヒト胃壁由 来の線維芽細胞とヒト胃癌株をco-cultureした結果、線 稚芽練胞、癌練胞共にMMP-1蛋白発現を認めたが、癌 細胞数が增加するに従い、線維芽細胞の発現する MMP-1蛋白の発現も強くなる傾向にあった。腫盷細胞 と宿主細胞との相互作用（液性因子、接着因子等）が 存在する可能性が推測され、細胞外マトリックスの代 諃機序を解明していくうえで興味ある所見が得られた。

301

胃租樴における Matrix

Metalloproteinases(MMPs)の遇剩発現

金沢大学がん研究所外科 1)、同研究所分子免疫部 2)、 富士薬品工業株式会社 3 )

野村英弘 1）2）、磨伊正義 1）、藤本昇 3）、

岡田保典 2)

癌の浸閏転移に関係するマトリックスメタロプロテイナー ゼ (MMPs) のうち、4 種類のMMPs (MMP-1, MMP-2, MMP-3，MMP-9) とそのインヒビターであるTIMPs

(TIMP-1, TIMP-2) の罢癌組織内での局在と産生量を 検討した。免疫染色 (46 症例) の結果、MMP-1, MMP- 2, MMP- 9, TIMP- 2 は癌細胞之間㑭の線維芽細胞に 局在するのに対し、MMP- 3 とTIMP- 1 は間質細胞にのみ 陽性であった。組織片の培養液（39症例）につきサンド イッチイムノアッセイ法にて測定したところ、4 種類の MMPs産生量はいずれも非癌部より癌組織で有意に高值を 示した。また、ゼラチンザイモグラフィー上、癌部におい て活性型のMMP-2 (59\%) とMMP-9 (31\%) を高率に認 め、活性型MMP-2の出現は癌細胞の壁内浸潤とリンパ管 内侵入とよく相関した。以上の結果から、胃癌組樴では癌 細胞之間質細胞由来のMMPsの過㮃発現とMMP- 2 の活性 化が認められ、その産生は主として胃癌細胞と間啠の線維 芽細胞で行われていることが示された。

302

の検討

国立仙台病院外科

斎藤俊博, 手島 伸, 正宗良知, 菊地 秀,

山内英生, 国井康男

[目的] slow moving protease (以下SMP) と plasminogen activator（以下pl-a) 活性を測定し、血清 CEAも含めて転移と予後について検討を加えた。

[対象と方法］ mp以上の進行胃癌42例を対象とし, pl-a，SMPの活性をelectrophoresisを施行し，検索した。

[結果] 1)転移形式に扔ける術前CEAとSMPとの関 連ではCEAが正常で，SMP陽性の症例は肝転移では33 $\%$ に過ぎいが，腹膜転移では $73 \%$ と高率に認められ た。同様にCEAが正常で, $\mathrm{pl}$-a陽性の症例は肝転移で は $33 \%$ であるが，腹膜転移では $67 \%$ と，SMP同様， 腹膜症例の症例に高率に認められ，pl-a, SMPの活性 の有無が腹膜転移の予知のパラメーターとなる可能性 が示唆された，2）予後との関連をSMPと pl-aの陽性 の有無別に 3 生率をみると，SMPでは，SMP陽性群と 除性群とも $40 \%$ 前後で差はないが, pl-aとの 3 生率で はpl-a陰性群は52.4\%であるが, pl-a陽性群は $26.3 \%$ $(\mathrm{P}<0.05)$ と有意に予後が不良であり, pl-aの有無と 予後との関連が示された。 
303

胃癌症例における第18番染色体長腕対立遺 伝子のへテロ接合性欠失と癌進展及び予後との検討 大分医科大学第一外科

井上徳司, 内野畺也, 宮原正樹, 大澤直文

下田勝広, 白石憲男, 尾迫俊克, 北野正剛, 小林迪夫

【目的】胃癌の第18番染色体長腕 (18q) 対立遺伝子 のへテロ接合性の欠失 $(\mathrm{LOH})$ を検索し臨床病理学的因 子扝よび予後との検討を行った。【対象と方法】 1983年1月より1994年2月までに当科にて治癒切除を 施行した cohesive typeの早期および進行胃癌症例 85 例を対象とした。癌部, 非癌部別にDNAを抽出し, $18 \mathrm{q}$ 上の2つの microsatellite marker (D18S58,D18S61) に対してPCRを行い癌部におけるLOHの有無を判定し た.【結果】(1)60例の判定が可能で, 17例のLOH症 例を認めた $(28.3 \%)(2) \mathrm{LOH}(+)$ 症例の組織型は, pap 5 例, tub1 3例, tub2 5例, por1 4例であった。(3)LOHの 有無でリンパ節転移に関して有意差を認めなかった。 (4)漿膜浸潤陽性例は LOH (+)症例9例, LOH (-) 症例8例 であり有意差を認めた。 $(\mathrm{p}<0.01)(5)$ 肝転移例 1 例は $\mathrm{LOH}(+)$ であった. (6)LOH(+)症例はLOH(-)症例に比 し有意に予後不良であった。 $(\mathrm{p}<0.01 ; \log$ rank test $)$

【結語】18qLOHは胃癌の進展に関与し, 予後と関係 があることが示唆された。

304 $2 \mathrm{~cm}$ 末満進行胃癌の臨床病理学的検討

<特にp53蛋白異常発現との相関について $>$

金沢大学がん研究所、外科

表 和彦、黄 承東、平野晃一、溝口雅之、 山下 要、野村英弘、藤岡 央、源 利成、 太田孝仁、磨伊正義

【目的】今回我々は小型浸潤進行胃癌を術前に診断する一 助として臨床病理学的諸因子とp53遺伝子異常の相関につい て検討したので報告する。【対象と方法】過去17年間に当教 室で経験した2 $\mathrm{cm}$ 末満の進行胃癌12例(進行癌の1.8\%)を対象之 した。癌抑制遺伝子p53の異常発現についてはABC法にて免疫 染色を行った。判定は 13 以上の癌細胞核に発現がみられるも のをp53蛋白異常発現陽性としたが、1及未満のものを(士)と亜 分類した。【結果】 p53蛋白の異常発現陽性例は3例(25\%)であっ たが、(士)をも含めると7例(58.3\%)であった。またp53蛋白異 常発現と組織型、脈管侵襲、リンパ節転移、予後などとの有 意な相関関係は認められなかった。【考察】胃癌においては p53遺伝子異常が進行癌の進行度や予後亡相関するいう報告 がある一方で相関しないという報告もある。今回我々の検討 では臨床病理学的諸因子とp53蛋白異常発現との相関関係は 認められなかったが、p53の染色性(士)をも含めると58.3\%の 症例にp53蛋白異常がみられることになり、p53遺伝子異常が $2 \mathrm{~cm}$ 末満進行胃癌の発生や進展に関与している可能性が示唆 された。
305 胃癌組織におけるp53 蛋白の過利発現と 予後に関する臨床病理学的検討

金沢大学がん研究所外科1)、金沢大学第 1病理2) 黄 承東1)、大井章史2)、太田孝仁1)、源 利成1)、 表 和彦1)、磨伊正義1)

(目的)本研究は胃癌におけるp53 蛋白の過剩発現亡臨 床病理学的諸因子及び予後との関係をみることにより、 p53 蛋白の過剩発現は胃癌生物学的悪性度の指標となりう るかを検討した。(対象と方法)金沢大学がん研外科で、最 近 7 年間に切除された胃癌 401 例を対象とし、p53 蛋白に 対するポリクロナール抗体(CM-1)を用い免度染色を行っ たた。p53の評価はは暗褐色に染色される核を計測し、 $20 \%$ 以上の癌細胞の核が染色された症例をp53 陽性とし、 陽性核が $20 \%$ 以下の症例はp53 陰性とした。(結果)胃癌 401 例のうちp53 陽性症例は118 例(29\%)で、陰性症例は 238 例 $(71 \%)$ であった。p53 蛋白の過剩発現之臨床病理学 的因子との関係をみたところ、深達度、肝転移、stage 等 との相関が見られなかった。リンパ節転移群のp53 陽性群 が陰性群より有意に高かった。intestinal type のp53 陽性率 は、diffuse typeに較べ有意に高かった。(まとめ)胃癌の diffuse typeのp53 陽性群は有意に 5 年生存率が低く、p53 蛋白過剩発現はリンパ節転移とdiffuse typeの予後の予湘に 関して、重要なparameterになりうるものと考えられた。

306 Reverse transcriptase-polymerase chain reaction（RT-PCR）を用いた胃癌の微小リンパ 節転移の診断

大阪府立成人病センター外科

平塚正弘、野口眞三郎、古河 洋、岩永 用、 安田卓司、中野博史、中森正二、大東弘明、亀山雅男、 佐々木 洋、甲 利幸、石川 治、今岡真義

【目的】胃癌の微小リンパ節転移検出法としてRT-PCR を用いた方法を考案し、その有用性を組織学的検索法 と比较検討した。

【方法】胃癌組織およびリンパ節より tota1 RNAを抽 出してkeratin 19 (K19) 遺伝子の mRNA をターゲット としたRT-PCRを行った。

【結果】K19 RT-PCRの感度は癌細胞 1 個／リンパ節細 胞 $10^{3}-10^{5}$ 個であった。胃癌患者 $(\mathrm{n}=12)$ より得たリ ンパ節 (n=100) を二等分し一方は組織学的 (H\&E染色) に他方はK19 RT-PCRで検索した。組織学的に転移陽性 のリンパ節 $(\mathbf{n}=7)$ ではすべてK19 mRNAの発現が認めら れた。一方組織学的に転移陰性のリンパ節93個の内、 14個（15\%）ではK19 mRNAの発現が認められた。

【結㖣】K19 RT-PCRは通常の組織学的検索では検出で きない胃癌の微小リンパ節転移を検出し得る感度の高 い検查法である。 
307

胃罊の增殖能・悪性度とガストリン分泌

瑟境；新部PCNA標識种、c-erbB2発現との阔連において 東海大学外科 $2^{11}$ 、東京医科大学病院病理 ${ }^{21}$

官治正雄 ${ }^{1)}$ 、生越雨二 ${ }^{1}$ 、 、中村健司 ${ }^{11}$ 、近藤泰理 ${ }^{1}$ 田島知郎 ${ }^{11}$ 、三富利夫 ${ }^{11}$ 、度田映五 ${ }^{2)}$

【目的】ガストリン分泌動態からみた胃密の增殖能 ・悪性度、予後との阑について㭘討を行った。【対象 と方法】対象任胃音切除症例622例て，街前に空腹時血 清ガストリン值を湘定した.ガストリン高值群 $(100 \mathrm{pg} /$ $\mathrm{ml}$ く)、低值群 $(100 \mathrm{pg} / \mathrm{ml}$ l)に分け、瘦部最深部を含めた パラフィン切片のガストリン、c-erbB2, PCNA (Dako社製 抗体)を用い免疫組樴化学染色を行った(PCNA標識率：

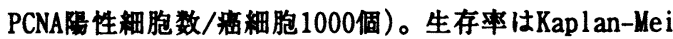
er法て表し，Cox's modelを用い予後因子の多変是解析 を行った。【桔果】1）血清ガストリン值が $100 \mathrm{pg} / \mathrm{ml}$ を超える群は $100 \mathrm{pg} / \mathrm{m} 1$ 以下の群に比し有意に予後が不 良て、ステージ別検期で同㥞であった。2）多变量解 析ては、低分化型 (por, sig)におけるガストリン值が有 意な予後因子でった。3）ガストリン高值群、低值群 の間で癌部のカススリン発現に差はみられなかったが c-erbB2の発現、PCNA標識率は高值群が低值群に比し有 意に高率であった。【桔語】胃㾇の增殖能、墨性度、予 後とカスストリン分泌骤境とに強い閔連があることが示 され、特に、低分化型癌の予後と強い相関が認められた。

308 胃癌組織におけるYyNPase活性の臨床的意

義について

東京女子医科大学附属第二病院外科

勝部隆男、今野宗一、我妻美久、三浦一浩、

若杉慎司、渡辺俊明、島川 武、石川信也、

成高義彦 矢川裕一、小川健治、梶原哲郎

[目的]胃癌組織におけるPyNPase活性について、臨 床病理学的因子との関連をみるとともに、その局在や 転移リンパ節についても検索してみた。

[対象と方法]対象は切除胃癌30例で、癌部組織の PyNPase活性 (HPLC法) を臨床病理学的因子 (stage、組 織型、間質量、浸潤增殖様式、リンパ管侵襲、静脈侵 襲、リンパ節転移)別に比較し、ABC法による免疫組織 染色を用いてその局在をみた。さらに、転移リンパ節 のPyNPase活性とその局在についてもあわせてみた。

[成績]胃癌組織におけるPyNPase活性はmedullary、 INF $\alpha \beta 、 \mathrm{v}(+)$ 例で有意に高值であった $(\mathrm{p}<0.05)$ 。局 在は癌細胞と間質細胞にみられ、癌細胞優位なもの 14 例と間質優位なもの16例に大別することができたが、 前者のPyNPase活性が高值だった。転移リンパ節にお いてはPyNPase活性は原発巣と差がなく、局在は癌細 胞とリンパ球にみられた。
309

用胃造設術の評価

群馬大学第一外科

細内康男、長町幸雄、竹之下誠一、原敬、持木彫人

(目的) 我々の教室では、胃全摘後の再建術式として、 横行結腸間置術(TCI)を施行し、QOLの向上を図ってき た。この術式の術後評価を行った結果を報告する。(方 法、結果) 胃全摘後TCI症例及びRoux en $\mathrm{Y}$ 再建術 $(\mathrm{R} \cdot \mathrm{Y})$ 症例を比較検討した。(1)摄食量の評価:TCI後の一日3 回掑食症例は、 2 年時 $85 \% 、 5$ 年時 $100 \%$ 、一日摄食量 が術前の $80 \%$ 以上であった症例は、 2 年時 $90 \% 、 5$ 年時 93\%であった。(2)術後逆流性食道炎の評価:内視鏡検査 で食道炎所見を認めた症例はTCI群 40 例中 3 例 $(7.5 \%) 、$ $\mathrm{R} \cdot \mathrm{Y}$ 群12例中 3 例 $(25 \%)$ であり、TCI群が低率であった。 $\mathrm{Tc}{ }^{99} \mathrm{~m} \mathrm{E} H \mathrm{IDA}$ 逆流シンチグラフィーにおける胆汁の食 道内逆流は、TCI群 $7.5 \%$ 、R-Y群 $8.3 \%$ あった。(3)栄 盖パラメーターによる評価:T.P、Alb、総リンパ球数、 T.chol值は両群間に有意差を認めなかった。体重減少 率は、2 年時TCI群 $6.9 \% 、 \mathrm{R} \cdot \mathrm{Y}$ 群 $17.2 \% 、 5$ 年時TCI 群 $5.9 \% 、 R \cdot Y$ 群 $17.1 \%$ あり、TCI群が優れていた(P<0.01)。 (4)術後胆囊結石症発生率はTCI 群33例中5例(15.2\%)、 R-Y群17例中4例(23.5\%)であり、TCI群が低率であった。 (5)耐糖能、消化管ホルモン動態による評価:TCI群はRY 群に比べ耐糖能、ガストリン分泌能が優れていた $(\mathrm{P}<0.01)$ 。(結論) 胃全摘後横行結腸間置術は、術後の QOL維持に有用な再建術式と結論できる。

胃全摘槙行結腸間置再建法の 術後長期栄養状態に関する検討

名古屋市立大学第 2 外科

小山浩、桑原義之、篠田憲幸、川村弘之、三谷真己、 佐藤篤史、成田清、加藤丈博、岡平樹洋、片岡誠、 正岡 昭

【目的】今回教室では胃全摘後の再建法として機械吻 合を用いた横行結腸間置再建法を採用し 3 年が経過し たため、術後の長期栄養状態につき検討した。

【対象】空腸間置法 (JIP) 11例、横行結腸間置法 (CIP) 8 例。

【結果】1. 術後半年と術後 2 年を経過後の諸検査をCI P群で比較したところ、体重は半年後 $84.6 \pm 8.4 \%$ に対し 2 年後 $86.2 \pm 5.3 \%$ で若干体重增加の傾向がみられた。 $\mathrm{TP}, \mathrm{ALB}, \mathrm{TG}, \mathrm{Ch}$ ol等の生化学検査に於いては有意差はな かったものの,TP, ALB, TGにおいて若干増加の傾向を認 めた。

2.術後愁訴はCIP群がJIP法に比して軽度であり、PFD試 験の結果からはJIP群は, CIP, control群に比して小腸の 通過が早く、30分後のインシュリン值は高值であった。

【まとめ】1.CIP法の術後長期の栄養状態は安定し ていると考えられた。2.術後愁訴はCIP法はJIP法に比 して少なく、食物の小腸通過時間も正常により近く、 タンピング症状の発生も少ないと考えられた。 
311 胃全摘術後の回結腸間置法再建における

代用胃の貯留排出能-RI法による術後早期と後期の 比較 -

慈恵医大第 2 外科 1 、同放射線科 2$)$ 、同アイソトープセ ンター3)

中田浩二1)、青木 洋1)、羽生信義1)、古川良幸1)、

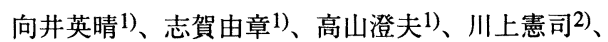
吉沢幸夫3)、青木照明1)

[目的] 教室では、手術で失われた胃の生理機能を再 建術式（回結腸間置法再建：以下IC再建）により補う ことで胃手術後障害が軽減されることを報告してきた。 しかし、IC再建術後早期では、食事摂取量も少なくダ ンピング症状がみられるなど、満足すべきQOLが得ら れていない。そこでIC再建術後早期と後期の代用胃の 貯留、排出能をRI法で測定し、その機序の解明を試み た。[方法] IC 再建術後早期（約 1 力月） 4 名、後期 (6 カ月以上） 5 名と健常人 7 名にRI法による胃排出能検 査を行い貯留、排出能を比較検討した。[結果] 術後早 期、後期ともに捸取量の約 5-6 割が代用胃内に蓄えら れ、貯留能は部分的に代償された。術後後期では健常 人と近似した排出曲線を示したが、術後早期には有意 な排出六進がみられた。[結論] IC 再建の術後早期では 代用胃のreservior機能は十分でなく、貯留、排出能は、 術後愁訴の改善と相関して経時的に改善がみられた。

\section{2 而全揞㭪後のJ-pouch再建法の模时}

\section{東京医科科大学第1 外科}

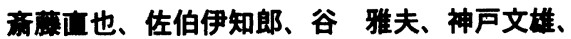
竹下公矢、迹管光夫

圆全墇術後にJ(jejunal) - pouch の Roux-Y再建 法 (JP-RY群 : 5例、J-pouch间正法(JP-1群 : 6 例)、従来のRoux-Y再建法（RY群：6例）、空稨间 量法（群：6例）を行い、街後6力月以上経過した

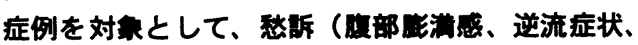
タンピンク症状）、1日の食克回数、1回摄取典、行

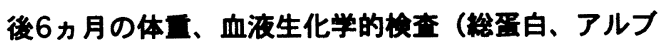
ミン、総コレステロール、トリグリセライド)の健を

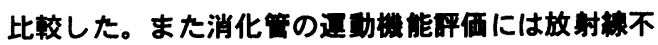
透遇マーカー(SITZMAR KS)を用い、術後2年以上経 過した症例（男性）では助唔も测定した。

[結果] JP-RY 群では愁訴、1日の食重回数、1回摄 取量、マーカーの排泄帮とも清足できる結果が得ら れた。JP-詳は眻に比ベマーカーの排泄は安定して いたか、愁訴、1日の食亭回数、1回提取昷では禹群 间に差を现めなかった。RY群では1日の食事回数、1 回摄取旦ともに他の3群に比べ劣っていた。体宜、血 液生化学的検查では4群间に童はみられず、明らかな 骨代楼異常はJP-群1例、RY群2例に现められた。
313 幽門側胃切除後空腸パウチ間置再建後の

残胃炎の検討 -Billroth I 法との比較一

金沢大学第二外科

木南伸一、三輪晃一、藤村隆、仲井培雄、加治正英 佐藤貴弘、川村泰一、野島直巳、広野靖夫、

津川浩一郎、伏田幸夫、米村豊、宮崎逸夫

幽門側胃切除術後の空腸パウチ間置再建 (JPI) 後の残 胃炎を、術後 4 年以上経過した、外来通院中の 21 例に 対し胃内視鏡 - 粘膜生検 (吻合部小弯 - 大弯、残胃小 弯中央・大弯中央の 4 簓所）を行い、Billroth I 法

（B-I ）11例と比較した。胃炎の所見は、シドニーシ ステムに数項目を加え、内視鏡所見は14項目で、生検 病理組織所見は5項目で記載した。残胃への胆汁逆流を 認めたのはJPI:14.3\%、B- I :63.6\%で、JPIに有意に少 なかっだ*。両群間の内視鏡所見の比較では、吻合部 発赤 ${ }^{* *}$ 、残胃発赤 ${ }^{* *} 、$ 脆弱性 ${ }^{* *}$ 、平坦びらん**、隆起 びらん*の所見陽性率が、JPIで有意に少なかった。組 織学的所見では、残胃大弯粘膜の炎症 ${ }^{*} 、$ 萎縮 ${ }^{* *}$ 、残胃 小弯粘膜の炎症 ${ }^{*}$ の各項目でJPIでのgradeが有意に軽度 であった。切除胃と残胃小弯の生検との比較で、炎症 所見の悪化を認めたものが、JPIでは $14 \% に$ 対し、B-I では50\%であっだ。(* : p $\left.<0.055^{* *}: \mathrm{p}<0.01\right)$ JPIは、B 一 I 法に比へ、残胃の炎症・萎縮の程度が、内視鏡検査 所見、生検組織像の双方とも有意に軽微であった。

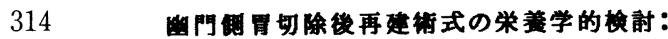

jejunal pouch interpositionとBillroth I 法の比聥 香川医科大学第二外科 ${ }^{11}$ 、大阪府立羽电野病院外科 ${ }^{21}$ 大林康二 ${ }^{11}$ 、東島哲也 ${ }^{11}$ 、小関萬里 ${ }^{11}$ 、中村煡司 ${ }^{11}$ 、 前田昌純 ${ }^{11}$ 、池田義和 ${ }^{21}$ 、网本公子 ${ }^{21}$

当科では1988年より、胃切術後陵害の軽減を目的に jejunal pouchによる再建を行っている。今回、jejun al pouch interposition (以下Pouch 群) をBillroth-I 法 (以下B-I 群)を対象とし栄美学的に比較検討した。

[対象と方法] stage I とstage II の胃㿋に対する幽門 側胃切除症例のうちpouch 群 24例、B-I 群58例を対象と した。両群に性差、年蜱に有意差はなかった。ベラメータ 一として、体重の㚆化、BMI(Body mass index)、血液生 化学所見(総蛋白、アイル゙、シ、A/G、総コレステロール、ヘモグ吡”ン、コリ ンエイララーゼ)及び小野寺のPNI(Prognostic nutritional index)を剆定し、QOLの指摽として食事回数、取量、 つかえ感等の自覚定状を調查した。

[結果] 体重、BMI、ChE、A/G、ヘそグ吡”ンはPouch群の成績 が良好な㑯向を示し、總蛋白、7ルブミン、總コレステロー川、PNIで は両群間に明らかな有意差は認めなかった。

[結語]Pouch群は自觉症状の面からはQ0Lの改善が示 唆されたが、栄養学的には差を認めなかった。今後、 他のペラメーターを含めた評価、检討が必要と考えられた。 
315

歩行数からみた胃切除後の骨代謝障害の

検討

東京医科歯科大学第 2 外科

仁瓶善郎、小嶋一幸、市川 度、西直人、河原寛人、永 合正浩、北鄉邦昭、伊藤雅史、平山廉三、三島 好雄

【はじめに】歩数計を用い胃切除術後の骨代謝障害との 関係を検討した。【対象】胃切除術を施行し、術後骨 塩量および一日歩行数を調査し得た99例。男性66例、 女性33例で平均年齢62歳、術後経過期間は平均 26 ケ月、 幽門側胃切除術74例、胃全摘術25例であった。【方法】 定量的 C T 法により骨塩量を求め、同性同年齢の骨塩 量に対する百分率を骨塩量比とし $80 \%$ 未満のを障害例 とした。MD/MS法では評点 4 以上を障害例とした。 3000 歩未満を $\mathrm{A}$ 群、3000歩以上 7000 歩未満を $\mathrm{B}$ 群、 7000歩以上を C 群とした。【結果】定量的 C T 法では MD/MS法より歩行数との関連が強く認められた。歩行 数と定量的 C T 法による障害例との関係をみると、高 齢者、男性、幽門側胃切除群でC 群において非障害例 が多い傾向が認められた。2年未満の症例では、歩行数 の多い群において非障害例が多く認められた。【結語】 胃切除術後の歩行数は定量的 C T 法による骨塩量比障 害と相関し、MD/MS法のそれとは相関が認められなかっ た。術後早期よりの歩行の励行が、胃切除術後の骨代 謝障害の予防に重要である。

\section{6 生体内分解性消化管吻合器による食道空腸} 吻合術の実験的並びに臨床的検討

聖マリアンナ医科大学第 2 外科

上杉仁、大矢和光、荘正幸、前田壽哉、河合敬雄、 石川修司、桜井丈、岩崎光彦、亀谷忍

生体内分解性消化管吻合器 (BAR; valtrac ${ }^{\mathrm{RT}}$ ) による 胃全摘術後の食道空腸吻合の報告は極端に少ない。そ こで、実験的に犬を用いた食道空腸吻合を検討し、臨 床使用による検討も行ったのでその結果を報告する。

【動物実験】ビーグル犬 6 頭に胃全摘術を行いRoux-Y の再建にて、食道空腸を端側にてBAR を用いて吻合し た。術後 $1,2,4,8$ 週後の吻合部を病理組織学的に検討 した、術後 1 週間目で既にlayer to layerの形での腸 管壁の癒合が見られ、BAR が脱落する 2 週間目で瘾合 はほぼ完成することを確認した。【郜床使用】胃全摘 術（空腸間置術）を施行した胃癌症例 8 例の食道空腸 吻合をBAR（サイズ外径 $25 \mathrm{~mm}: 7$ 例 $28 \mathrm{~mm}: 1$ 例）で行った。 術後縫合不全は見られず、経過は良好であったがBAR の残存する術後 17 日目までは 5 分㐨以上の食事摄取で ほぼ全例に吻合部の通過障害を訴え、BAR の脱落と共 に劇的に改善した。術後、吻合部狭窄を 1 例認め、内 視鏡的拡張術で容易に改善した。【結語】BARによる 食道空腸吻合は、吻合状態は良好であるが、経口摂取 など術後管理に注意を要すると考える。
317

GIAを用いた新しい膵切離法

一胃癌手術における膵脾合併切除一

虎の門病院消化器外科

梶山美明, 鶴丸昌彦, 宇田川晴司，堤 謙二,

木八下義宏，土肥健彦，松田正道，橋本雅司，

渡辺五朗, 早川健, 澤田壽仁, 秋山洋

膵脾合併切除を伴う胃癌手術において最大の合併症は 膵液㜢である. 従来, 膵切離断端の処理は用手縫合す る方法が用いられてきたが定型的で安全, 確実な方法 が確立されているとは言いがたく，われわれは1987年 から TA-55を用いて膵切離を行いさらに1994年からはG IAを用いたより簡便で迅速な膵切離を開始し良好な成 績を得た。【対象と方法】膵脾合併切除を行った胃癌 手術例の内1994年以降GIAを用いて膵切離を行った 35 例(GIA群)を対象とし，TA-55を用いて膵切離を行った 184例(TA群)を対照として検討を行った。【結果】GIA 群では膵液瘻の頻度は有意に低率であり $(\mathrm{P}=0.035)$, 膵断端の追加縫合はGIA群で有意に不要であった $(\mathrm{P}<0$. $0001)$ 。主膵管の結紮はTA群では82.6\%に行ったがGIA 群では2例のみに施䘕 GIAでは主膵管の結紮は不要で あると考えられた $(\mathrm{P}<0.0001)$. 術後出血はGIA群では 皆無であった。GIAではstapleは横, 列ともにより密 に配列していた。【結語】GIAは膵管，血管の閉鎖効 果に優れ膵切離の新しいmethodになると考えられる.

318 胃上・中部癌の術後機能評価とQ O L

大阪医科大学 一般・消化器外科

野村栄治、岡島邦雄、磯崎博司、一ノ名正、

藤井敬三、泉 信行、大山直雄

【目的】教室では、胃上・中部胃癌に対し空腸間置を 伴う噴門側胃切除あるいは幽門側胃覀全摘を行ってお り今回両術式の有用性を検討した。【対象と方法】対 象は術後 1 年を経過した空腸間置を伴う噴門側胃切除 11例（噴切群）之幽門側胃亜全摘10例（亜全間置群） であり、それぞれ対照として、胃全摘空腸間置（全摘 群）16例と胃亜全摘・Billroth I 10例（亜全群）を用 いた（いずれもD 2 以上）。QOLの検討はアンケート調 查、食道・胃内視鏡検查、血液生化学検查を行い、機 能評価は食事刺激後の血中ホルモン濃度・血糖值測定 と排出能検查（アセトアミノフェン法）を行った。

【結果】A）噴切群は全摘群に比較し 1）貧血がなく、 食事椇取量の減少・腹部症状の発現頻度が少なかった。 2) 食後 15 分の血糖値上昇食後 30 分以内のセロトニン の上昇率が少なかった。3)排出能検查にて食後 15 分に おける墬落排出も有意に抑制された。B）亜全間置群 は亜全群に比較し1)胸やけ症状がなく、内視鏡所見で も食道炎の所見を認めなかった。2)機能面では亜全群 と同様であった。【結論】空腸間置を伴う噴門側胃切 除術・幽門側胃严全摘術は有用な術式と考えられた。 
319 術式別にみた胃癌術後愁訴に関する検討 慶應義塾大学外科

星屋泰則、大谷吉秀、五十嵐直喜、石川秀樹、

藤田晃司、石塚裕人、林 害孝、桜井嘉彦、

吉田 昌、大上正裕、久保田哲朗、熊井浩一郎、

北島政樹

【目的】胃癌術後愁訴に対する術式の影望を明らかに するためにアンケート調查を行った。【対象および方 法】術後 1 年以上経過した $\mathrm{m}$ 癌症例 93 例を対象として、 術後愁訴、食生活の変化、便通異常、活動状況の変化、 患者の手術に対する满足度に関して、直接インタビュ 一もしくはアンケート送付により回答を得た。【結果】 術式の内訳は、内視鏡的粘膜切除術（EMR） 20 例、腹 腔鏡下手術（LAP） 15 例、開腹縮小手術（縮小） 27 例、 開腹標準手術（標準） 31 例であった。術後新たな愁訴 の出現、食生活の悪化は EMR、LAP では認めず、縮小、 標準で有意に高かった。便通異常は EMR、LAP では認 めず、縮小、標準の順に発生率は上昇した。活動状況 の悪化は EMR、LAP に比し縮小、標準で有意に高かっ た。また手術に対する满足度をスコアー化し、平均ス コアーを算出すると、EMR : 2.86 、LAP : 2.83、縮小 : 2.26、標準 : 2.42 であった。【結語】各術式を術後愁訴 の点から開腹標準手術と比較すると、開腹縮小手術は、 大きな差がなく、EMR、LAP は良好な結果が得られた。

320 胃切除後残胃炎発生機序の検討

岩手医科大学第 1 外科

伊藤浩信旭博史 寺島雅典大森浩明 池田健一郎高金明典 清水光昭斎藤和好 [目的]胃切除術後の残胃炎発生機序について、胃液 内性状、胃粘膜防御因子であるPotential difference (PD)、活性酸素動態、H. pyloriの面から検討した。

[対象亡方法] 1991年4月より胃切除後内視鏡検查を施 行した187例 (B-I 153例、B-II 23例、PPG5例、R-Y6 例) を対象とした。退院時に内視鏡検查を行い胃液内胆汁 酸、トリプシン浱度、pHを測定した。胃炎の有無を観 察した後PDを小弯口侧、肛門側、大弯口側、肛門侧で 測定した。生検組織で過酸化脂質 (LPO)、SOD、GSH-px 活性を測定した。Hpは抗体価および分離培養を行った。

[結果] 胃切除後残胃炎は $46 \%$ にるられ、特にB-Iで 高頻度であった。胃炎例では胃炎なし例より胃液胆汁 酸、トリプシン濃度、 $\mathrm{pH}$ 名高かった。PDは胃炎例は胃 炎なし例より各点において低値を示した。LP0およびS OD活性は胃炎例が胃炎なし例より高值を示したが、GS H-px活性は差がなかった。また胃炎の有無ではHp抗体 価、分離培養ともに一定の関係はみられなかった。 [まとめ]胃切除後残胃炎は腸液逆流による胃粘膜防 御因子の低下、活性酸素による影整が考えられ、Hpの 関与は少ないものと考えられた。
321

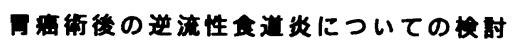
群里大学第 2 外科，县沢病院 ${ }^{11}$ ，贯病院 ${ }^{21}$ 中神克尚、大和田進，中村正治、竹吉来，小川暂史，

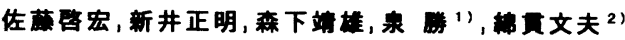

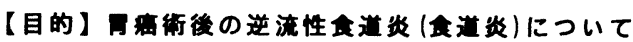

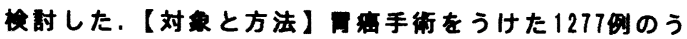

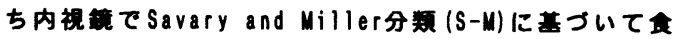

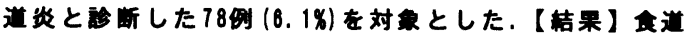

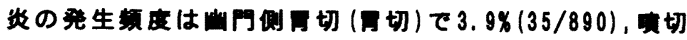

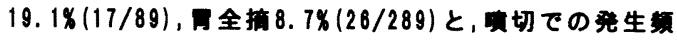

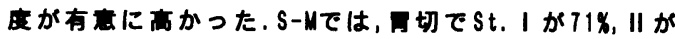
26\%，林が3\%，Nが0\%であり，哄切で各々 24\%，47\%，18\%，12 \%、全揞で各々 27\%，42\%，23\%，8\%であった.四切で埋症な むのが有壳に多かった、再建法別にみた食道炎は、同切 BーIで4.3\%、BーIIて2.3\%にみられた.结間量の例、分

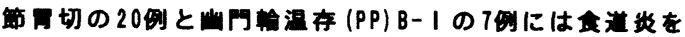

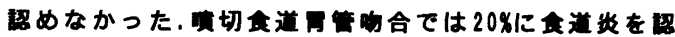

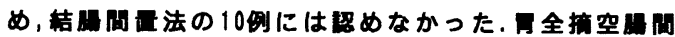

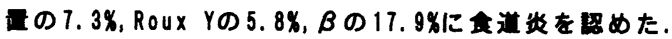

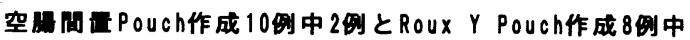

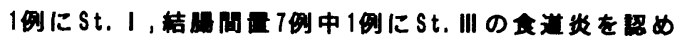

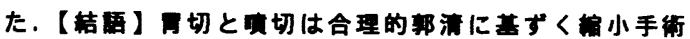

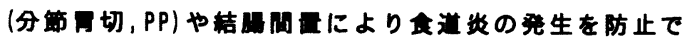
きるが、全捕では更なる脔时とエ夫が必要である。

322

胃癌の進行度判定における補助的診断法と

しての腹腔鏡の有用性について

大阪大学第二外科

矢野雅彦、塩崎均、村田厚夫、井上雅智、関本貢䦜、 田村茂行、戎井力、門田守人

[目的] 高度進行胃癌症例に対してはC T, MR I 等の画像診断だけでは手術先行か化学療法先行かで判 断に困る場合がある。そこで我々は高度進行胃癌患者 に対する進行度判定に腹腔鏡を用いた腹埶内の観察が 有用であるかどうかを検討した。

[方法］高度進行胃癌患者 5 例に対して腹腔鏡検査 を行った。原則として手術室にて局所麻酔下に腹腔鏡 を挿入し腹膜播種、肝転移、腫場の胃槳膜面への浸潤、 多葳器浸潤、リンパ節転移の有無を検索した。また原 則として全例に術中洗浄細胞診を行った。

[成績］5例中 3 例に術前の画像診断で指摘のでき なかった腹膜播種が、また 1 例において微小な肝転移 单が見つかった。しかし腪への浸潤の有無や 2 群以上 のリンパ節転移の有無に関しては観察困難であった。 全例において検査に伴う合併症は認めなかった。

[結論］因癌の術前進行度判定において特に微小な 転移单の検索に腹腔鏡検査は有用であり他の画像診断 と併用することにより正確な進行度判定ができるもの と考えられた。 

Hemi-double stapling methodによる幽門侧胃 部分切除(B-I 法)の経跧

山口大学第 2 外科

樋脇一久、丹黒章、岡正朗、鈴木做

胃良性腫瘍に対して低侵襲下に手術を行うべく腹 腔鏡補助下に湾上部小切開で幽門側胃切除 (BillrothI 法再建)を施行した 1 例を経験したのでこれを報告 する。全麻下に膀部より腹腔鏡を挿入し、左側腹部よ り $10 \mathrm{~mm}$ のトラカールを挿入し、正中に $65 \mathrm{~mm}$ の皮 膚切開をくわえ、2 個のケント鈎にて吊り上げを行い、 視野を確保した。正中の小切開創より十二指腸切離後、 大弯书よび小弯の切離は左側のトラカールよりハー モニックスカルペルを併用して行った。胃切除後、我々 の教室で考案した Hemi-double stapling method にて Billroth-I 法再建を行った。すなわち胃切離予定 線の大弯側より $1 / 2$ までを $75 \mathrm{~mm}$ の linear stapler で切離後、切除側胃に加えた小切開より $\mathrm{CDH}$ 本体を 挿入し、大弯側の切離端より穿通させて、十二指腸内 に挿入した detachable head の anvil shaft と接合し、 胃十二指腸吻合を行った。次に $75 \mathrm{~mm}$ の linear stapler を小弯側に向かって挿入し、胃を完全に切離 した。術後疼痛は軽度であり、術後回復も急速かつ順 調であり、この術式は有用であると思われた。

324 2 Dカラードプラ・電子リニア型超音波内 視鏡による胃癌術式決定亡予後の推定 東京大学医学部第 3 外科学教室

安田 秀光、橋本 政典、上西 紀夫、山口 裕和、 清水 伸幸、大原 毅

【目的】胃癌 510例に対して超音波内視鏡 (EUS) を 行った。2 Dカラードプラは196例でに血流の評価も行 い、内視鏡所見、術中所見、標本の血管面積、リンパ節 転移数と比較し、治療の指標としての有用性をみた。

【方法・装置】装置は東芝・町田社製EPE703FLを用 いた。癌最深部を含んだ $1 \mathrm{~cm}^{2}$ 内の $100 \mu$ 以上の血管の 断面皘や数などを画像解析装置で測定した。

【結果・考察】(1)II 型胃癌のEMRの適応の決定には、 超音波内視鏡 と内視鏡所見の一致で判断することで $82 \%$ 正診し、過大評価は微小浸潤例であった。(2)胃癌縮 小手術の決定に際し、術中硬結 (一) では $72 \%$ が深達度 mで、硬結 $(+)$ では $65 \%$ が梁達度 sm であった。術中 所見とEUS - 内視鏡所見と合わせて 2 者以上の一致を もって判断することで、深達度 $\mathrm{m} て ゙ 74 \%$ 、深達度 $\mathrm{sm}$ $83 \%$ 之改善をみた。(3) 2 D カラードプラ施行例でみる と、陽性例ではリンパ節転移陽性率は $30 \%$, 陰性例では $13 \%$ 差がみられ、これは癌病巣の面積とは相関せず、 癌病巣の厚みと相関した。厚みの平均が陽性例では $0.798 \pm 0.154$, 陰性例では $0.446 \pm 0.081$ と差があった.
（EMR）の適応拡大症例の検封

大阪大学医学部第二外科

谷口亿章、塩崎均、田村茂行、井上雅智、

矢野雅彦、川西賢秀、樽井武彦、前野良人、

村田曆夫、門田守人

【目的】EMRの適応は教で、2cn以下のIa型と1cn以下

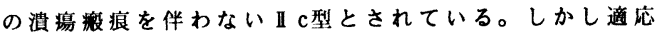
をひろげて実施する事も少なくはない。今回、適応外 症例の治療成績と追加治療について検封した。【対象】 適応を広げた症例は、他の悪性疾患の合併: 4例、高踰： 2例、高度肺機能障害: 1例、患者の希望: 1例、確定部断の ため (GroupIV):2例、手術拒否: 1 例、切除可能と判断:3 例の14例であった。【結果】術前 sn楊と郝断した症例 は6例で、この内4例に局所再発を認め3例に胃切除術を 追加した。病変の大きさが適応外の症例は8例で、切除 後病理部断でs教の症例が2例、断端 $(+)$ の症例が 3 例で あった。切除可能と部断した最近の 2 例は再発は認めて いない。【考案】適応を広げた症例の治療成績は不良 で、適㤁㹡大には注意が必要と考えられた。しかし sn 㿋においても根治症例があり、他の悪性疾患との合併 症例なとでは適応昖大可能と思われた。また、経検者 が安全に切除可能と判断できる病変で再発はなく、切 除手技の向上と共に適応範囲の拡大可能性が示された。

塚原康生 ${ }^{11}$ 、高見元敞、高田俊明、辻仲利政、 北田昌之、柴田高、室谷昌弘、新居延高厷、 飯原啓介、塚本文穴、小川稔、森琛癿、木村正治、 花田正人 ${ }^{21}$

胃癌の縮小手術に㳉、まだ問題点が多い。今回は術 前診断の精度を再検討し、縮小手術を含めた合理的な 胃癌手術に関し検討した。

（対象）当院で過去饥間の胃癌手術例は1676例ある。 今回はわれわれが綰小手術をはしぬとする合理的な手 術を開始した最近 5 代間の症例 555例（うち早期癌 40例; 不検索の対象上した。

(方法) 沭前に早期上診断した 219例のうちで総合診 断が進行癌であった16例について肉眼病型と深達度診 断および術式について再検討を加えた。

（成績）16例の病型は II c 9、II c+III 1、III + II c 3、 II c+ II a 2、II at II c 1 で觕凹型がほとんよ゙を占めた。 深達度についてmpのものは見直し診をしても早期を否 定しきれなかった。我々は原則として 清、sm癌に $\mathrm{D}_{2}$ 厚清、mp癌には $\mathrm{D}_{2+a}$ 鄭清を行ってい るが、術中の壁深達度よリンパ節の所見を加味してほ ぼ満足できる結果を得た。術前診断で陷叫型、大きい ，变、潰場併存例は縮小手術に注意を要すると考える。 
327

早期周恙に対する合理的手術

石川県立中央病院一般消化器外科

山田哲司、几木慎悟、龍沢廉、宇野裕、吉野

裕司、土田敬、藤网重一、北川晋、中川正昭

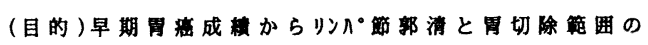
两面から桻小手術に㛟䞑を加えた。

(対象およひ方法) 対象は19年間に当科で治坃した

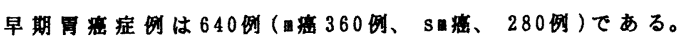

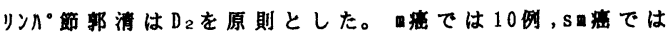
52 例のリンク゚節転移症例を証めた。 3 に㑇めた。员以上の症甽における移状况より、D ，手術で $96 \% 、 D_{1}+7$ 番郭清手街で98\%、D

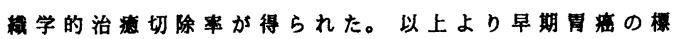
劷手術としては $D_{1}+7$ 番郭清で十分であると考えられた。

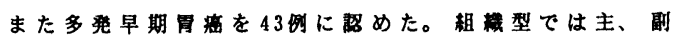
病果とも同一耝樴型であるものが93\%をしめていた。主、 剧病果の占拠部位はM、A 領域の同区域、およひ接区

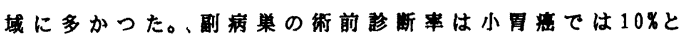

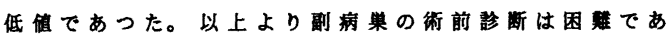
り、切除籍囲の樎小を行えば早期周嵒の䄪5\%において 睑病竹の取り残しの可能性があるものと考えられた。

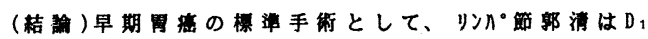

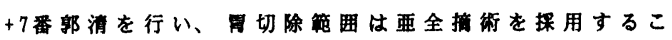

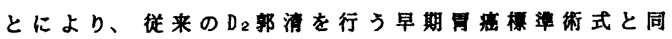
様な成楼かえられると考えられた。

\section{8 sm胃癌に対する縮小手術の適応}

\section{山形目立中央病院外科}

福島紀雅, 市原征洋, 東 敬之, 高橋 閏,

淥間 久, 池田栄一

【目的および対象】当科において過去12年間に切除 された初発単発sm胃癌528例を対象とし，sm胃癌に対 する縮小手術の可能性を検討した。【結果】sm胃癌全 体のリンパ節転移率は13.2\%てあり, リンパ節転移の 危険因子は, 女性, 隆起+陷凹型, 睡癔径, sm深部浸 閏てあった。このうち縮小手術の適応になりやすい， 最大腫瘍径 $20 \mathrm{~mm}$ 以下の $\mathrm{sm}$ 胃癌の検討ては, 185例中n $(t)$ 15例 ( $n 1: 10$ 例, $n 2: 5$ 例)，n(-) 170例，リンパ節転移 率8.1\%てあった。リンパ節転移の危険因子は， $8 \mathrm{~m}$ 胃 癌全体と同様，女性（リンパ節転移率：15.7\%），隆起 十陷凹型（転移率：20.0\%），sm深部浸閏（転移率： 15. 2\%) てあった。【結論】リンパ節転移の危険因子 より, 男性, 隆起型もしくは陷凹型, 睡瘍径の小さい もの, sm浸閏程度の浅いものが樎小手術の可能性を有 している.しかし $20 \mathrm{~mm}$ 以下のsm胃癌ても8.1\%(m癌全 体の5倍， $20 \mathrm{~mm}$ 以下のm疮の的7倍）のリンパ節転移率 があり，かつ術前にはsm浸閏程度および陷凹型の腫瘍 径の正確な診断が困難なことを考慮すると，sm胃疮に 対するリンパ節郭清を伴わない縮小手術の適応は，慎 重でなればならないと考えられる。
329 術前早期胃癌と彰断され、2 群以上のリン パ節に転移を認めた症例の検討

癌研究会付属病院外科

犬塚 央、大山繁和、田中知行、井利雅信、石原 省、 太田恵一朗、高橋 孝、中島聰總、西 満正

【目的】早期胃癌が広範にリンパ節転移を認める症 例の診断、治療法の検討を目的とした。

【対象と方法】1985年から1994年における、早期胃 癌切除例 1287 例の内のM-SM, n2 症例 32 例について、こ れらの組織学的特徴及びリンパ節転移部位を検討した。

【結果】肉眼型はIIa 2例、IIc 20例、IIa+IIc 3例、 IIc+IIa 2例、IIc+IIb 1例、IIc+III 4例、組織型は tub1 4例、 tub2 6例、por 8例、por sig 4例、sig 3 例であった。また、脈管侵襲の高度なものが多く、壁 侵達度はm 5例、sm 12例、mp 6例、ss 5例、se 4例で 正診率は $53.1 \%$ であった。占拠部位別のリンパ節転移 (n2@)部位は、上部で\#7、\#9、\#11、中部で\#7、\# 9、下部では \# $8 \mathrm{a}$ が半数以上を占めていた。生存率は $69 \%$ 、再発形式は肺、肝、骨、卵巣、リンパ節転移 等であった。

【まとめ】リンパ管侵襲の高度な症例が深達度診断 を誤る傾向にあり、術中のリンパ節診断が病期の評価 に重要であると考えられた。

330 早期胃癌に対する縮小手術後経過観察中

問題となった症例について

東京慈恵会医科大学第三病院外科

三森教雄、村井隆三、岩本公和、若林真理、平野純、 楠山明、片岡順三、長山瑛、安藤 博、伊坪喜八郎 （はじめに）早期胃癌に対する縮小手術として内視鏡 下胃粘膜切除術 (EMR) 、経皮経胃壁内視鏡下粘膜切除 術(PTEMR)、腹腔鏡鏡下胃楔状切除術 (LWR)、開腹下 胃局所切除術を行っているが遺残、異時、同時多発胃 癌などが生じる可能性がある。今回われわれが行った 縮小手術後経過観察中に問題となった症例について報 告する。（症例 1 ）80歳男性。胃体上部に II c, を認め たが、合併がありEMR を行った。tub1, m断端陰性と判 断し経過観察を行っていたが94年 5 月の内視鏡にて局 所再発を認めた。（症例 2 ）51歳男性。94年 6 月、胃 体上部後壁の II c に対しPTEMR 行った。tub2, m, 8x6mm , margin(-)で経過観察中、95年 5 月、胃前庭部に II c を認め95年 6 月、胃切除術を行った。（症例 $3 ） 65$ 歳 男性。94年 6 月、胃体中部に II c を認めたが、合併症 があり開腹下胃楔状切除術を行った。tub2, m, margin （†）であったが追加切除は行わず内視鏡にて切除部の biopsy(-) が得られていたため経過を見ていたところ 94年12月に他部位に I c を認めた。 以上の問題点を報告する。 
331

罚要深達度における術前診断と組織診断の

止沴染 〜技術向上之縮小手術適心㹡大を目指して〜 慶應義熟大学外科

们川秀樹、熊非浩一蚛、ti風㨁喜、藤田晃司、

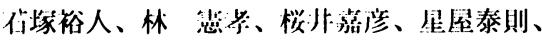

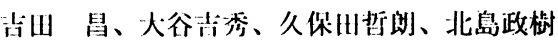

肖釈術後の長期生存例增加に伴い、特に $\mathrm{m}$ 癌に対し

ては各種の綃小手術が㛟詿されている。綃小正術を行 う際の理論的裹付けのため、超音波内視鏡を導人の後 1995 年 6 月までに当院外科で施行された 325 例 の早期胃癌に対する㙕闭除術の、上部消化管内視鏡、

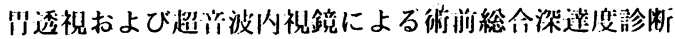

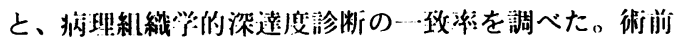

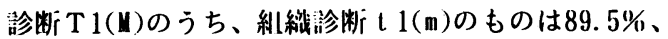
$\mathrm{t} 1(\mathrm{sm})$ は $10.5 \%$ T $1(\mathrm{SM})$ のうち、 $\mathrm{t} 1(\mathrm{~m})$ は $54.5 \%$ 、 $\mathrm{t} 1(\mathrm{sm})$ は36.4\%。また、T2のうち $566.7 \%$ は $1(\mathrm{sm})$ に修正された。逆に、組織診断で $\mathrm{t} 1(\mathrm{~m})$ のうち、術前 診断 T1(N)のものは58.1\%、T $1(\mathrm{SM})$ は $38.7 \%$ t 1 ( m)のうち、T1(N)は11.1\%、T1(SM)は72.2\%。なお、 $\mathrm{t} 2$ のうち $12.5 \%$ は 1 (SW) と診断されていた。本検討 での 㫊の正診染は89.5\%であったが、T1(SM)のう ち t 1(m)に修正されたものが54.5\%と高比率で、縮小 手術拨例はまだ増やすことが可能であり、術勈診断の さらなる精度问上が必而と思われた。

332 組機多模性および權成組機型からみた mp

\section{胃癌の検封}

千葉大学第一外科滝口伸浩、布村正夫、更科厸実 斉藤典男、幸田圭史、早田浩明、尾崎和義、菅谷芳樹 鈴木弘文、近藤英介、知久 媇、若月一雄、吉村光太郎 古川留魅子、石川文彦、安富 淳、中島伸之

【目的】胃癌では様々な組織型の混在がみられる。そこ で、癌の発育と組織型の関係を知るために、組織多様 性および構成組織型について $\mathrm{mp}$ 癌を対象に検討した。 【対象と方法】対象は $\mathrm{mp}$ 胃癌切除症例 63 例で、 $\mathrm{mp}$ 深 達度を $\mathrm{mp} 1$ (内輪笳表層 $1 / 4$ までのもの)、 $\mathrm{mp} 2(\mathrm{mp} 1$ 、 $\mathrm{mp} 3$ 以外のもの)、 $\mathrm{mp} 3$ (内的筋を越えるもの)に細分

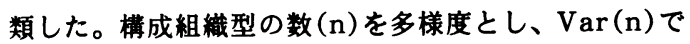
示した。【結果】 $1 . \mathrm{mp} 1: 16$ 例、 $\mathrm{mp} 2: 27$ 例、 $\mathrm{mp} 3$ : 20 例であった。2. $\mathrm{mp}$ 胃瘦の主組織型は por が半数を 占め、次にpap の割合が高かった。また先進部組織型 では por が 40 例を占め、先進部で分化度が高くなる症 例はなかった。3. 組織多様性は81\%にみられ、Var3 以上が約 $40 \%$ を占めた。多様度が大きいほど、深達度 が梁く、n2、3 が多かったか、主組織型 por の比率は

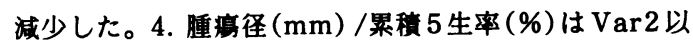
下：39.1/87.15、Var3以上：45.5/72.05であった。 【結語】組織多様性は、腫㴼の発育と密接に関係してい ることが示唆された。
333 ss胃癌の検討

山形県立中央病院外科

市原征洋,東敬之,福島紀雅,渋間久

ss胃癌は、mp胃癌とse胃癌の中間的存在として、取り 扱いが曖昧であり、明らかな治療方針が確立されてい ない。今回我々は、1983年から1992年の10年間に当 科において切除された初発単発ss胃癌のうち、根治度 A,B症例 249例を対象とし、臨木病理学的検討を加えた。 術後、組織学的にss胃癌と診断された対象群の中でも、 術中の肉眼的槳膜面浸潤程度には、かなりのバラッキ がみられたが、S0からS3八と槳膜面への浸潤程度が進 むに従い、リンパ節転移程度も進行する傾向がみられ た。つまり、術中の肉眼的漿膜面浸潤程度は、術後の 組織学的診断との診断誤差があっても、リンパ節郭清 範囲決定の為の指標に成り得ると考えられた。また、A 領域のss胃癌ではNo.16とNo.12リンパ節にそれぞれ約8 \%、約3\%の転移が認められ、M領域のss胃癌では No.16リンパ節に約 $18 \%$ の転移が認められた。この結果 より、A及びM領域のss胃癌においてNo.16リンパ節(特 にNo.16a2からNo.16b1）の郭清はNo.12,13a,14vリンパ 節の郭清と同程度に重要であると考えられた。また、 予後に影響を与える因子として有意差が認められたの は、リンパ節転移程度と肉眼的獎膜面浸潤程度であっ た。

\section{4 胃粘液癌（muc）の臨床病理学的検討}

\section{札幌厚生病院外科}

片岡昭彦, 近藤征文, 高橋雅俊, 中村隆志, 岡田邦明，石津寛之，益子博幸，西田靖仙， 小川秀彰, 横山良司

【目的】胃粘液癌 (muc) の臨床病理学的特徴を明ら かにする.【対象と方法】1963年から1991年までの初 発胃癌症例 3346 例をmuc群 とmuc以外の組織型群に分け 臨床病理学的事項を比較検討した.【結果】1.muc 群は108例(3.2\%)，2. 性別・年秢：男77例, 女31例で 平均年秢は55.7歳. 3. 占居部位： A 領域61例 (56.5\%), $\mathrm{M}$ 領域 28例(25.9\%), C 領域5例(4.6\%)， 3 領域14例 (13.4\%). 4. 壁深達度 : m 6.5\%, sm 13.9\%, mp 12.0\%, ss $15.7 \%$, se-si 51.9\%. 5. v(t): 早期癌2例 (9.1\%), 進行癌 22 例 (25.6\%). 6. $1 \mathrm{y}(t)$ : 早期癌 7例 (31.8\%), 進行癌 66例 (76.7\%)。 7. H(t): 進行癌で5例 $(5.8 \%)$. 8. $\mathrm{P}(\boldsymbol{t})$ : 進行癌で25例 (29.1\%). 9. $\mathrm{n}(\boldsymbol{t}): \mathrm{m} 0$ 例, sm 5例(33.3\%), mp 6例(46.2\%), ss 13例 (76.5\%), se -si 47例(83.9\%). 10.5 年累皘生存率: $\mathrm{m}, \mathrm{sm} \mathrm{100 \% ,}$ mp $84.6 \%$, ss $52.7 \%$, se・si $36.0 \%$.【まとめ】胃粘 液癌 (muc)の特徽 (1)胃の下部に多く上部に少ない (2)壁深達度が深い (3)腹膜播種性転移率が高い (4) ンパ管侵䃞率が高い (5)リンパ節転移率が高い 
335 大腸癌肝転移例の切除後再発に関する検討 岡山济生会総合病院外科

三村哲重, 筒井信正, 児玉雅治, 松村年久, 赤在義湝, 岡本康久, 戸田耕太郎, 木村秀幸, 大原利憲, 広瀬周平, 片岡和男

【目的】大腸癌肝転移例の肝切除後再発危険因子の解 明之, 朋开発例での時間学的検討から, 残肝再発に対 する治療法を考察した。【対象と方法】大腸癌肝転移 の 治療切除例50例について以下検討した。(1) a. 原発单 のDukes分類 b. 肝切除の時期 c. 肝切除術式 d.TW e. 肝 転移個数 f.腫瘍最大径 g.輸血の有無 各々の因子別の生 存率を求めた。(2)再発様式。(3)肝再発例での初回肝切 除時点での推定腫瘍径。【結果】(1)全体の生存率は3生 $47 \% ，$ 生: 37.6\%で因子別の生存率では，原発坚の Dukes 分類，輸血の有無で有意差をみた。(2)再発例は 26例 (52\%) で, 残肝再発18例。残肝のみの再発は13 例で8例では再発時単発であった。再発確認は, 初回肝 切除後 2 ヶ月から 15 ヶ月平均 8 ヶ月目であった。(3)再発 腫痬径は $1.5 \sim 4 \mathrm{~cm}$ 平均 $2.7 \mathrm{~cm}$ で, CEA doubling timeか ら初回肝切除時点で腫瘍径は $0.2 \sim 27 \mathrm{~mm}$ と推定された。

【結語】Dukes C あるいは輸血施行群は再発危険群で ある。残肝再発は，すへて遺残結節と考えられ，初回 肝切除時点で 精査方法を高めること，また 術後早期と いえども 再切除により根治が得られる。

336 大腸癌手術後 5 年以上経って再発した症 例の検討

都立駒込病院外科

宮入純一、森武生、高橋慶一、安野正道

当科において術後 5 年以上で再発した症例は 10 例あり、 根治切除1537例中の再発例 248 例の $4 \%$ にあたる。他院初 回手術例 4 例とあわせ 14 例について、その特徴と治療上 の問題点について検討した。

14 例中血行性再発のみは11例で、うち8例に再発巣切 除が行われ 3 年生存 4 例、 5 年生存 1 例がある。血行性再 発例は初発癌が高分化腺癌や脈管侵熟の弱い悪性度が 低いものが多く、初回手術時にごく少数の転移癌細胞 が遭残し成長したものと考えられた。5年以上経って発 見されても根治切除可能例むあり、再発巣発見 1 年以内 時にCEAの上昇が認められた症例が $50 \%$ らったこのた め術後 5 年以上経過した例でも血液学的なfollow upの 必要性が示唆された。局所再発 3 例は初回手術時に腺管 形成のある粘液癌や壊死傾向の強い高分化腺癌例で、 ewが近いために局所に癌細胞が遺残し、5年以上かかっ て成長したと考えられた。発育速度そのものはCEA doubling timeからみても通常の局所再発例に比して明 らかに遅い症例が多かった。3例ともに再発巣切除が施 行されたが 1 年 6 ヶ月以内に全例死亡し、ewが疑われた 症例に対する局所再発巣の発見の遅れが反省された。
337

\section{検討一日米大腸鹰手術症例の比較検討から一}

自衛隊中央病院外科, 防衛医科大学校第 1外科1）

Stanford大学外科2)

長谷和生, 望月英隆 1), 倉永憲二, 宇都宮勝之, 村山 道典, 藤野啓一, 津田倫樹, 岸本幸次, 小林秀紀, 渡邊

千之, 石山 賢, 玉熊正悦1), Clayton Shatney2)

防衛医科大学校, 自衛隊中央病院におけるCur A, B大 腸癌手術症例 980 例 (JP) 之米国Stanford大学での793例 (US)を対象として, 日米間で大腸多発癌, 重複癌症例の 特徴について比較検討した.【結果】(1)多発癌: 発生頻 度は日米間で差がなく(9\%:8\%),JPではUSに比べ異時性 癌発生間隔: 5 年以内, 進行度: 進行-早期, 早期-早期の組 合わせ, 発生部位: 同一・隣接領域, 第1癌の占居部位:S 状結腸, 組織型:高分化の症例が夫々高率であった.JPで はJP単発癌に比べS状結腸が高率であったが, USでは占 居部位による差はなかった. (2)重複癌: JPの発生頻度は USに比へ低率であり $(7 \%: 11 \%)$, 他荗器癌はJP: 胃, 子宮, 乳腺, US: 皮䖉, 膀胱, 前立腺の順に多かった.JPではUSに

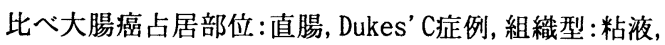
高分化の症例が夫々高率であった.JPではJP非重複癌に 比べ粘液癌が高率であったが, USでは組織型による差が なかった、【結語】日米間の比較を通じて大腸多発癌・ 重複癌症例の臨床病理学的特徵を明らかにした。

338 検討

\section{腹腔鏡手術を施行した早期大腸癌症例の}

\section{慶應義塾大学外科}

酒井信行 渡透昌彦 寺本龍生 西堀英樹

藤井俊也 山本聖一郎 千葉洋平 石井良幸

奈良井慎 石原雅已 北島政樹

（目的）教室では1992年より早期大腸癌に対し腹腔 鏡手術を導入した。今回は本法の有用性につき検討し たので報告する。

（対象）1992年6月より1995年8月までに当院外科で 施行された腹腔鏡手術症例53例である。

（結果）局所切除はm癌と診断された28例に施行さ れ、2例がsm癌(sm1 1例、sm2 1例)であった。部分切 除はsm癌と診断された25例に施行され、5例がsm癌 (sm2-3)、3例がmp癌であり、そのうち $\mathrm{mp}$ 癌の3例は 術中n(+)であったため、開腹手術に変更された。手 術時間は平均3時間36分士1時間38分であり、捸食開始 は平均 $2.6 \pm 1.1$ 病日、退院は平均 $7.1 \pm 2.6$ 病日であった。

（考察）腹腔鏡手術は徒来の開腹手術に比べ術創が 小さく創痛は軽微で美容上優れている。また、本法は 早期に蟠動が得られるため経口摄取の開始も早く早期 退院を可能にした。

（まとめ）腹腔鏡手術は早期癌に有用な治療法の一 つであると考えられた。 
サーヴェイランス

大阪逓信病院外科、同 第2臨検*

丸山博英、丸橋 繁、德永 勝、増田慎三、瀧口修司 松井成生、矢野 浩、立石秀郎、衣田誠克、弥生恵司 綾田昌弘*、岡本 茂*、岡村 純

【対象】1983年より1994年までに当科で経験した大腸 癌手術症例は400例である。そのうち手術後、経過観察 中CFを行った症例は143例 $(35.8 \%)$ である(検査回数1 10 回 / 症例; 観察期間は8 135力月、平均52力月) こ の143例のうち癌、腺腫などの異常所見のみとめられた 39例 $(27 \%)$ について臨床的検討を行った。【結果】年 龄分布は32才から77才までで、平均年龄は58才であっ た。性別は男25例、女14例であった。占拠部位では、 初発部位は盲腸 1 例、横行結腸 3 例、下行結腸 3 例、S状 結腸14例、直腸18例であった。経過観察中に発見され た癌は 5 例 5 病変 (cancer in adenoma、4病変: $1 \mathrm{p}$, 径 $13 \mathrm{~mm}$; $1 \mathrm{p}$, 径 $11 \mathrm{~mm} ; 1 \mathrm{sp}$, 径 $25 \mathrm{~mm} ; 1 \mathrm{~s}$, 径 $15 \mathrm{~mm} ; 2$ 型, 径 $20 \mathrm{~mm}$ 、 1病変)で、占抛部位は盲腸 1 病変、横行結腸 2 病変、下 行結腸 1 病変、直腸 1 病変であった。手術後癌の発見さ れるまでの期間は、13力月から106力月 (平均50力月) であった一方、腺腫は32例 56病変(54病変: $1 \mathrm{~s}$, 径3-7 $\mathrm{mm} ; 2$ 病変: $1 \mathrm{p}$, 径 $15 \mathrm{~mm}$ )で、占拠部位は盲腸 5 病変、上 行結腸 11 病変、横行結腸19病変、下行結腸10病変、S状 結腸6病変、直腸5病変であった。手術後腺腫が初めて 発見されるまでの期間は、5力月から114力月 (平均30力 月)で、ついで2回目に腺腫が発見されるまでの期間は4 から75力月 (平均11力月)であった。【結語】大腸癌を 可及的に早期に発見するために手術後 1 年以内にCFを 行い、それ以後長期にわたり1年間隔で厳重に監視が必 要であると考えられる

大腸絨毛状腫瘍 394例の臨床病理学的検討 東京女子医科大学 消化器外科

天満祐子、鈴木衛、吉田勝俊、井上雄志、 安原清司、高崎健

過去 6 年間に当科で病理組織学的に診断された大腸 の䄉毛腺腫および腺管䄉毛腺腫は 394例でありそのう ち 372 例は内視鏡的切除施行, 22例は外科的切除を施 行した。内視鏡的一括切除した 327 例は腫瘍径 $3 \sim 40$ $\mathrm{mm}$, 平均 $13 \mathrm{~mm}$ であった。内視鏡的切除した 372例中85 例(22.8\%) に癌合併を認め, 腫瘍径別癌合併率は $5 \mathrm{~mm}$ が3.6\%，6〜10mmが11\%,11〜15mmが27.9\%,16〜20mmが $32.1 \%, 21 \mathrm{~mm}$ 以上が $42.9 \%$ と大きくなるほど高かった。 85例中 䕐は82例， sm癌は 3 例であった。手術症例 22 例は腫䶍径 $22 \mathrm{~mm} \sim 80 \mathrm{~mm}$ ，平均 $43 \mathrm{~mm}$ と大きく 22 例中 18 例 （81.8\%）に癌合併を認めた。18例中 m癌は14例， $\mathrm{sm}$ 癌 は 2 例, pm, ss癌も各 1 例ずつ認めた。 また内視鏡的 切除施行後に外科的切除された症例は 6 例あったが, 腫瘍径大きく数回の内視鏡的切除にても完全切除でき ず肉眼的遗残を認めたものが 5 例あり組織学的に $\mathrm{sm}-\mathrm{m}$ assive invasion 認め追加腸切除したものが 1 例であ った。。[まとめ]内視鏡的切除でほとんどの䄉毛状 腫瘍は治療可能であるが完全切除不能なものは初回よ り外科的切除すべきである。
341

再発形式からみた下部進行直腸癌術前照射

療法の効果に対する検討

奈良県立医科大学第一外科 ${ }^{1)}$, 同腫場放射線医学 ${ }^{2)}$ 畑 倫明 ${ }^{1)}$, 石川博文 ${ }^{1)}$, 藤井久男 ${ }^{1)}$, 山本克彦 ${ }^{1)}$, 西川徹 ${ }^{1)}$, 森田敏裕 ${ }^{1)}$, 吉川周作 ${ }^{1)}$, 中野博重 ${ }^{\text {(), }}$ 吉村 均 ${ }^{2}$,大石 元 $^{2)}$

当教室では1988年4月から下部進行直腸癌症例に対 し原則として術前放射線療法（体外照射30Gy+腔内照 射40Gy）を施行してきた。今回術後の初回再発形式 を骨盤内再発と骨盤外再発に分けて評価し術前放射線 療法の効果について検討した。【対象と方法】1985年 4月から1994年10月までにA' 以上と診断し側方郭清 を含む根治術を施行したRb直腸癌症例中, 照射症例 27 例と非照射症例 27 例についてフォローアップし, 初回 再発形式に関して検討した。【結果】非照射群では9 例に照射群では 4 例に再発を認めた。照射群は1例 (3.7\%) に骨盤内再発を認め非照射例の 7 例 $(25.9 \%)$ と比較し有意に低率であったが, 骨盤外再発に関して は明らかな差は認めなかった。また組織学的には壁深 達度 a 1 以下, リンパ節転移 n 1 以下の術前照射群で は骨盤内再発を認めなかった。【結語】我々の行って いる術前放射線療法は術後の骨盤内局所再発の予防に 有用であると思われた。

342 直腸癌に対する術前放射線照射および放射 線温熱併用治療が創鹪治虑に与える影靁

自治医科大学消化器一般外科

片岡孝、小西文雄、古田一裕、柏木宏、岡田真樹、 金澤曉太郎

目的：直腸癌術前の放射線照射、放射線温熱併用治療 が、術後の創傷治㾑におよぼす影響を検討した。

対象および方法：対象は術前に放射線化学併用治療 ( $\mathrm{R}+$ Chem群)、放射線温熱化学併用治療 $(\mathrm{R}+\mathrm{HT}+\mathrm{Chem}$ 群)を 施行した直腸癌で、腹会陰式直腸切断術例である。各群 における術後の創傷治癒の状態について検討した。

結果 : R+Chem群 18 例、R+HT+Chem群 17 例で、治癒良好と 判定した症例は、R+Chem群8例、R+HT+Chem群7例であった。 術後に骨盤死腔炎をきたし創の治癒に1か月以上を要し た症例は、R+Chem群10例、R+HT+Chem群8例であった。また、 術後会陰創が離開した症例は、R+Chem群 0 例、R+HT+Chem 群 2 例であった。各群 2 例計 4 例では、手術時に大網あるい は腹直筋を骨盤腔に充填し創傷治癒は良好であった。

結論：直腸癌の術前放射線照射例では、術後の創傷治 癒の悪化が認められた。当科で施行している術前治療の 条件下では、放射線照射に温熱治療を併用しても創傷治 瘉がさらに悪化することはなかった。大網あるいは腹直 筋の骨盤内充填は、術後の骨盤死腔炎の防止に有効であ ろうと考えられた。 
国立がんセンター東病院外科

新井竟夫、小野正人、谷山新次、白井劳則、

杉湿正典、清家和裕、新村兼庰、石井洋、

伊䔖雅昭、竟㗬正

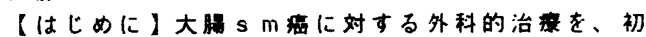
回より外科的切除を施行した症例と内梘鏡的治滕に 追加切除した症例とにわけて橡对した。【対象】遍去 3 年间に外科的切除された大䐬 $\mathrm{sm}$ 瘦 52 例である。 初回より外科的切除施行したもの(以下A群) は2 7 例、内梘鏻的切踰後に追加切除したも心(以下B群) は2 5 例である。【結果】A群の手術要因は1)大き さが $3 \mathrm{~cm}$ 以上，2)術前深㟟度が $\mathrm{s} \mathrm{m} 2$ 以上、3)

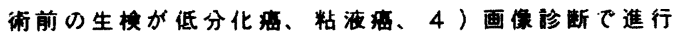

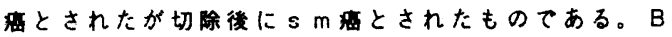

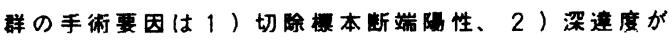

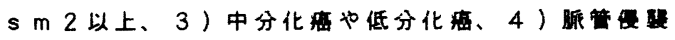
阵性のものである。実祭のリンバ節轱症例はA群で

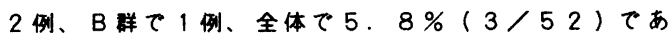

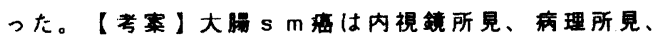
画使此断を考にし、A群に间してはその要因があれ ば今啳も外科的治袮の方針でよいと思われる。B群に 间してはほほ全例2)の要因を有しているが、3)、 4)の要因が豆椹するものには転移例もみられ、4つ の要因のリスクのスコアー化も必要と考えられた。大 きさ、肉眼型は臨床病理学的意味合いはあまりないと 考えられた。

344 消化器外科手術術後の肺血栓塞栓症

足利赤十字病院外科

龟山哲章、藤崎真人、平畑忍、前田大、

長谷川博俊、小島由光、松本昌久

肺血栓塞栓症 (以下 P E ) は、欧米諸国では発生頻 度が高く、死亡率も高い疾患であり、わが国において も近年增加傾向にある。また、P E の発生誘因の一つ に手術などの観血的処置があげられるが、消化器外科 領域においては、発生頻度などの检討はあまりなされ ていない。今回我々は、1987年1月から1995年8月まで の当院の消化器外科手術術後合併症としてのPEの発 生頻度、臨床像を検討した。

同期間の消化器外科手術総数は、2,762例であり、 その内PEを疑った症例は28例 $(1.0 \%) 、 P E$ と確 定診断した（肺血流シンチグラフィにて久損像を認め た）症例が28例中 14 例 $(50.0 \%)$ であった。確定診断 症例の内訳は、胃癌 11 例（内 1 例は直晹癌との同時性

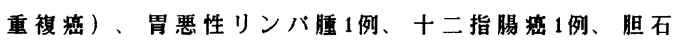
症（腹膛鏡下胆摘術）1例であった。平均年舲は、67. 1歳、男女比は、 $1: 1.3$ 、平均手術時間は、 5 時間 56 分、 発症までの平均期間は、 $3.8 \mathrm{P} O \mathrm{D}$ であった。 治療としては、ヘバリン、ワーファリンの投与を行い、 全例軽快した。

以上文献的考察を加え、報告する。
345 炎症例の検討

皮見市民病院外科胃腸科 ${ }^{1)}$, 同 眼科 ${ }^{2}$

牧野哲也 ${ }^{1}$, 野沢 寛, 高田 理, 和田真也, 木元文彦, 若狭林一郎, 村田修一, 清崎克美, 浅井宏志 ${ }^{2}$

経中心静脈高カロリー輸液法(以下IVH と略す)は消 化器外科手術に欠くことの出来ない補助栄養手段であ る。しかしIVHなどによる真菌性眼内炎の報告も増加 しており，当科で経験した症例について検討をおこなっ た。[方法］1994年 1月より12月までに経験した真菌 性眼内炎6 例 (A 群), 真菌感染によるカテーテル発熱 およびなんらかの感染巣を有しながら真菌性眼内炎 を起こさなかった11例(B群)を対象に諸要因を検討 した。[成績] 年令ではB B群のほうが高かった。性別 には差異がなかった。IVH 插入期間にも差異はなか った。原疾患についてはB 群のほうに悪性疾患が多 かった。患者の全身状態としての真菌感染が証明さ れた時期のパフォーマンスステータス・スコアは B 群が むしろ高かった。[結論] 真菌感染は日和見感染など 免疫力がおちている患者, 高齢者, 悪性疾患患者に発 生しやすいといわれていたが, 比較的全身状態の良い 患者にも発生していた。社会復帰も考え視力障害など の後遺症の残らないように注意するべきである。

346

胃・大腸癌悪液質の免疫・栄養状熊に及

ほすサイトカインの関与について

日本大学第 1 外科

柴田昌彦, 竹川本夫, 根津健, 大原守貴, 斉藤良人, 森健一郎, 滝沢秀博, 三宅 洋, 天野定婎, 黒須康彦

胃大腸癌において癌の進行ならびに悪液質の形成に ついてサ仆们関連可溶性分子の变轱を検討した。対象は Group $A$ (健常者)と胃大腸癌患者113例であり，後者は Group B(リソn節枟移・遗隔枟移ともに陰性)，Group C(リ ンク・節枟移阳性)，Group D(徳液質群: 嵒隔枟移または再 発病巣を有し,3个月間に5\%以上の体重減少あるいは血清 中アNプミ值が $3.0 \mathrm{~g} / \mathrm{d} 1$ 以下を呈した症例)に分類した。ま ず，可溶性 IL-2レ七7゚タ-(sIL-2R, BIA法)，可溶性 TNFレ七プ タ-1(sTNF-RI， BLISA法)およびネオプテリン(RIA法)淵度を測

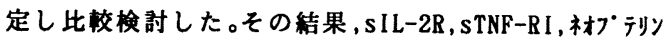
ともにGroup Dにおいて他群に比し高値を示した。また，

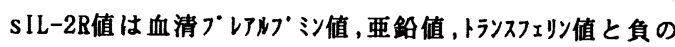
相関を示した。STNF-RI值もプレTNプ ミン值、トランスフェリン值， retinol binding protein値と負の相関を示し，IAP值と 正の相関を衿めた。材デリン值は単球数と正の相関を認 めた。このように癌の進行と悪液質の形成に T cell系の 活性化やTNFの関与並びにマクロファージの活性化が関係する とともに栄養状態の悪化を示すむのと考えられた。 
347 直腸手術時の体位に関する椎討

漛田保健衛生大学医学部消化器外科。

社会保険埼玉中央病院外科"

前田耕太郎、丸田守人、内海佁明、遠山邦宏、

滝沢健次郎、佐藤美信、舆村鄵浩、升森宏次、

橋本光正" 、細田洋一郎"

(目的) 直腸手術に道切な体位を明らかにするため に、X線学的に種々の体位につき梌討した。(对象お よび方法)直腸の手術を施行した 7 例を対象とした。 病変の局在部位は、Rs 2 例、R as 1 侧、 $\mathrm{Rab} 1$ 例、 Rb 3 例である。方法は、直腸と聑骨上縁をマーキンク 嗳、患者の侀面より仰卧位、碎石位、腰部高位の碚石 这で骨盤部のX線写真を撮影し、術者の視野の应置と なる天湖より見た直腸肛門侧下端と优骨上縁、第 5 腰 椎下端との位置関䋆を梌討し、視野展閉の指標とした。 さらに、手術は腰部高位の碎石位で行い、手術を施行 した 5 人の術者に、これまで行っていた研石位と比較 して視野の展開について算問し、腰部高位の体位につ いての評価を行った。(結果) 卯卧垃を暲石位にする ことにより、直腸下端が尾例に移動し、さらに部高 位にすることにより恥骨が尾侧へ移動し、実際の視野

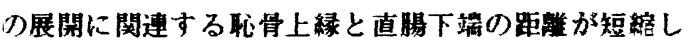
た。術者の評洒では、Rs の部位の手術以外の全例で視 野の展開が良好になったと評洒された。

348 エンドトキシン刺激による血管内皮細胞の 接着分子発現および白血球との接着に対するへパリン 様グリコサミノグリカン(h-GAGs)の作用

昭和大学藤が丘病院外科 ${ }^{1)}$, 大阪大学荗器制御部門 ${ }^{2)}$

山口真彦 ${ }^{1)}$, 北村直康, 松宮彰彦, 熊田殸, 宮坂昌之 ${ }^{2)}$

[目的]消化器外科感染症においてもエンドトキシン 血症は重篤な病態を惹起するが、その重要な初期変化 はエンドトキシン(LPS)によって活性化された血管内 皮細胞に白血球が接着することである。われわれは内 皮細胞を保護し抗炎症作用をもつとされるh-GAGsを 用いてLPS刺激による血管内皮細胞の接着分子発現及 び白血球との接着に対する作用を検討した。

[方法]ヒト血管内皮細胞にLPS とh-GAGsを加えて4 時間後に接着分子発現をELISA法で検討した。また、 内皮細胞をLPSで4時間刺激し、ヒトの白血球との接 着をh-GAGs存在下に静止及び非静止下で検討した。

[結果及び考察]h-GAGsはLPS刺激により増加した内 皮細胞上の接着分子発現を抑制しなかったが、活性化 された内皮細胞と白血球の非静止下での接着を有意に

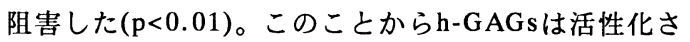
れた内皮細胞と白血球のより生理的な非静止下での接 着を阻害することによって抗炎症作用をもち、エンド トキシン血症の惹起する重篤な病態の発生予防に有用 であると推察された。
349 エンドトキシン腹腔内投与ラットでの肺,

肝, 腎の好中球接着一生体蛍光顕微鏡による観察一 東京大学第 1 外科, 同中央手術部*

韓 一秀, 齋藤英昭*, 安原 洋, 深柄和彦, 松田剛明, 稲葉 毅, 井上知已, 林 明㶹, 古川 聡, 武藤微一郎

【目的】腹膜炎や胆管炎などに続発するエトトトキジ血症 による蔵器障害には好中球が関与している，好中球の 血管への接着を定量的に捉えるためには標識好中球を 用いた生体蛍光顕微鏡による観察が有効である。肺な どへの標識好中球接着に影響を及はす LPS の腹腔内 投与量と, 標識好中球投与後の体内循環時間を決定し, 各臓器への接着状態を検討した。【方法】ラッにLPS を腹腔内投与し， 4 時問後に標識好中球 $3 \times 10^{6}$ 個を頚 静脈投与した，肺，肝，腎を摘出，生体蛍光䫓微鏡で 観察し，接着した標墥好中球を数えた。(1)LPS 腹腔 内投与量：対照群, $200,2000 \mu \mathrm{g} / \mathrm{kg}$ (2)標識好中球の 体内循環時間：投与直後， 2,5 分後に藏器を観察し た.【結果】(1)LPS 腹腔内投与量 : $200,2000 \mu \mathrm{g} / \mathrm{kg}$ 両群は有意差なく, 対照群に対し有意に増加していた。 (2)体内循環時問：3碓問に有意差はなかった。(3)肺 への接着は肝, 腎よりも多かった。【結語】本㳯いで のLPS腹腔内投与量は $200 \mu \mathrm{g} / \mathrm{kg}$, 標識好中球体内循環 時問は 2 分問が妥当で, 肺への接着が顕著であった。

350 細菌性腹膜炎モデルでの好中球の腹膜へ の接着と腹腔への淩出 - 生体蛍光顕微鏡による観察東京大学第一外科, 同手術部 ${ }^{11}$

深柄和彦, 斎藤英昭 ${ }^{1)}$, 安原洋, 韓一秀, 井上知巳, 林明燦, 稲葉毅, 古川聡, 松田剛明, 武藤徹一郎 【目的】細菌性腹膜炎での好中球の炎症局所への接 着と遊走, 滲出を生体䖢光顕微鏡を用い検討した.

【方法と結果】(1) 好中球の腹腔内渗出之腹膜への接 着：ラット $(\mathrm{n}=10)$ にE. coli $10^{7}$ (腹膜炎群)または生食 (対照群)を腹腔内投与した. 3 時間後に蛍光標識好中 球 $3 \times 10^{6}$ を頝静脈投与, 2 分後に犠死せしめ腹腔洗浄液 中の渗出好中球数を測定, 腹膜(大網, 腸間膜, 壁側腹 膜など）の接着好中球数を生体蛍光顕微鏡で調べた. 腹膜炎群は対照群より有意に腹膜への接着好中球数 (73 vs 39), 洷出好中球数が多く(7vs $\left.1 \times 10^{6}\right)$, 両者に 相関を認めた $(\mathrm{p}<0.05)$. (2) 接着好中球数の経時的変 化: (1)と同じモデルで $(n=36)$, 腹腔内投与 10 分, 1,5 時間後に標識好中球を投与した. 腹膜接着好中球数 は，10分後は差がなく，1，5時間後に腹膜炎群で対照 群より多く(1hr: 47 vs $24,5 \mathrm{hr}: 47$ vs $25, \mathrm{p}<0.05)$, 腹 膜中では大網, 腸間膜に多かった.

【まとめ】本モデルは好中球血管内皮接着研究に有 用で, E. coli 投与 1 時間後から好中球の大網, 腸間膜を 中心とした腹膜血管内皮への接着が認められた. 
351 IGF-1投与によるbacterial translocation (BT) 防止効果の機序-回腸末端の各種サイトカイン、へ ルパーT細胞およびマクロファージの動向について 千葉大学第 1 外科 ${ }^{1)}$,同動物実験施設 2 )

杉浦敏之 ${ }^{1)}$ 、田代垔彦1)、山森秀夫 ${ }^{11}$ 、森嶋友一1)、大

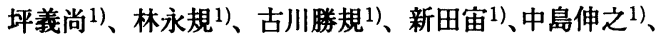
伊藤勇夫 $\left.{ }^{2}\right)$

IGF-1によるBT防止効果に関連して腸管のサイトカイ ンとヘルパーT細胞およびマクロファージの変化につい て検討したので報告する。【对象と方法】7週輀の雄性 SDラットをTPN管理し, 5 日後背部に約 $20 \%$ III度熱傷 を作成し、直後より IGF-1 $4 \mathrm{mg} / \mathrm{kg} /$ dayを持続投与する 群(IGF-1 群, n=12) と生食を投与する群(control群, n=10) に分けた。48時間後に儀死せしめ,回腸末端の一部から 蛋白質を抽出,溶解し,IL-6, IL-10, TNF- $\alpha$ を測定した。 またヘルパーT細胞とマクロファージの表面抗原に対す る抗体を用いてELISAを施行し,細胞の小腸での数を相対 値で表現した。【成績】IL-6とTNF- $\alpha$ はcontrol群に比し IGF-1群でやや少ない傾向にあったが有意差はなく,一方 IL-10は有意にIGF-1群で低值であった。また,ヘルパーT 細胞とマクロファージは両群間で差はなかった。【考察、 結諭】今回の検討ではIGF-1投与により腸管壁のヘルパ 一T細胞とマクロファージおよびIL-6, TNF- $\alpha$ の量は変 化しなかった。しかし,免疫抑制性サイトカインである IL-10の量は有意に減少しており,これが腸管局所の免疫 能を高め,BT防止に有利に動いている可能性がある。

352 潰瘍性大腸炎の腸管外合併症、ステロイド 合併症に対する外科治療（大腸切除術）の効果（多施設 集計）

東京大学第 1 外科

樋口芳樹、洲之内広紀、篠崎 大、武藤徹一郎 研究協力施設 >兵庫医大 2 外 (宇都宮譲二) 、浜松医 大 2 外（馬場正三）、新潟大 1 外（畠山勝義）、奈良医 大 (中野博重) 、自治医大一般消化器外 (小西文雄) 東京女子医大 2 外 (亀岡伸悟) 、兵庫医大 4 内（下山 孝）、長崎大 2 内（牧山和也）、秋田大 1 内（千葉満 郎）、弘前大 1 内（棟方昭博）、大阪市大 3 内（小林絈 三）、滋賀医大 2 内（馬場忠雄）、東京医大 4 内（斉藤 利彦)

[目的］厚生省特定疾患難治性腸管障害調查研究班で は、潰瘍性大腸炎の腸管外合併症、ステロイド合併症に 対する外科治療の効果を検討した。［対象亡方法］14の 研究協力施設より集積した、潰瘍性大腸炎で合併症を有 する大腸切除症例 158 例 (総合併症数 375 例) を対象亡 た。これらの合併症の発症時期・割合、術前発症した合 併症の術後の転帰を検討した。[結果] 1)合併症の発生 時期は術前295例、術後73例、不明7例で、80\%が術前に 発症した。2)術前発症295例中、術後に軽快・治癒222例 $(75.3 \%)$ 、不変62例 $(21 \%)$ 、増悪 2 例 $(0.7 \%)$ 、死亡1例 $(0.4 \%)$ 、転帰不明 8 例 $(2.6 \%)$ で、術後に軽快・治癒する合 併症が多かった。3)成長障害、肝機能障害、関節炎・関 節症、ブドウ膜炎・虹彩炎、皮虞発疹、結節性紅斑など は術後に軽快・治癒する症例が多く、osteoporosis，白内 障などは術後も不変が多かった。［結語］多くの腸管外 合併症に対して外科治療の効果が認められたが、基質的 変化を来したステロイド合併症では効果が少なかった。
353

\section{夕ミン付加成分策䔔就の果}

東京恶恵会医科大学外科学誈座第 1

落田哲二、尾高真、松田実、田辺義明、

佐伯知行、小林進、伊坪喜八郎

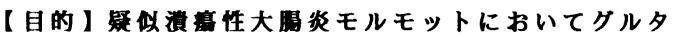

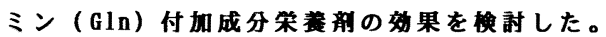

【方法】モルモットに連日およそ1.5g/kgの入-carrag

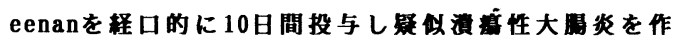

䨤した。その後モルモットを2群に分け、半數の7匹に 対しては市貶の成分策垬剖を（ED群）、残りの7匹に 対しては2\%のGInを付加した成分管羬㓮を5日間投与し た（G群）。モルモットを実䮲開始から15日目に開腹 し、それそれの粘䐜の蛋白含量、オルニチン崖宸酸

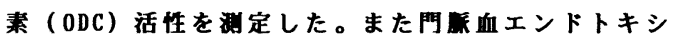
ン（LPS）湛度をエンドスペーシー法で睌定した。

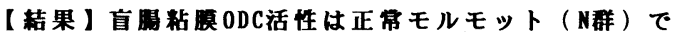
224.4(77.4)(nean (sd))pnol、ED群で97.9(70.5)pnol、 G群で71.5(32.1)pnolとED群、G群ではN群に比へて有 意に低下していたが、ED群、G群間には有意差は詔め られなかった。門愿血LPS流度はN群で4.1(2.0) pg/al、 ED群で71.2(21.0) pg/n1、G群で 25.3(10.8) pg/n1とG群 ではED群に比へて有意に（P<0.01）低值であった。

354 放射線性直腸炎に対する経仙骨式 approachを用いた肛門括約筋温存手術の有用性 山口大学第 2 外科

小倉 寛、岡 正朗、硲 彰一、森近博司、鈴木 敞

【目的】放射線治療後に発生した直腸炎は進行性で 治療に難渋する。教室で新たに導入した経仙骨式 approachによる肛門括約筋温存術式を報告する。

【適応と成績】教室では 25例の放射性直腸炎を経験し た。原疾患は子宮頚癌21例その他4例で、照射線量は 25〜50Gyであった。うち9例に対して本術式を施行し た。手術適応となった直接的症状は下血が6例、直腸 胵瘦 2 例、直腸胵膀胱瘦1例であった。術後経過は良好 であり、肚門管最大制止圧は術後平均 $50.8 \pm$ $7.2 \mathrm{cmH} 20$ と術前値に比較して著明な低下はなかった。 また、排便回数は3〜4回/日、便失禁はなく肛門機能 は良好に保たれていた。

【手術方法】障害腸管が長い場合はまず経腹的に approachする。経仙骨式には、jackknife positionで肛 門挙筋を恥骨直腸筋直上まで後正中線で切開し、病変 部腸管を切除後、吸収系で端々に吻合する。diverting colostomy をおき、3ヶ月経過後にこれを閉鎖する。

【結語】経仙骨式 approachによる肛門括約筋温存下病 変腸管完全切除術を改良施行し、ほぼ満足すべき結果 を得た。 
355

時的変化

兵庫医科大学第 2 外科

石井洋光, 楠 正人, 中尾宏司, 山村武平,

宇都宮譲二

[目的]雄性Lewisラ卟を用い同系全小腸移植を行い、 中枢神経系と壁内神経系が完全に離断した移植片の壁 内神経叢の変化を電気生理学的手法を用いて移植後 2 年目まで経時的に検討した。〔方法〕短期観察群 : 移 植後1 (G1W)、2(G2W)、4(G4W) 週目群および成熟コ吅一群 (AC) の空腸を採取し、表面灌流装置に懸架し電気刺激 を加え、各種遮断薬を用いて等尺性に筋条片運動を記 録、比較検討した。長期観察群 : 移植後 2 年目群 (G2 Y) および老齢コ吅ル群 (OC) を作製し、上記と同手法を 用いて比較検討した。【結果及び結論】移植群は短期 及び長期観察群共に、壁内神経の分布ハ多ー决変化する のにもかかわらず、エンロール群 $(\mathrm{AC} 、 O \mathrm{OC})$ に比して同程度 の運動亢進状態が認められた。G1W、G2W群はAC群に比し 列ン作動性分画が増加しており、幼㥅容体の感受性 の亢進が考えられた。一方、G4W、G2Y群では逆に コ柞 動性分画の減少、それに変わる非アトレナ少・非列作動 性分画が増加した。以上、非アトレ归・・非列y作動性分 画が移植腸管運動維持のため重要な役割を果たしてい ることが示唆された。

356 保存小腸の管腔内洗浄のグラフトに与える 影響に関する実験的研究

香川医科大学第 1 外科”、同第 1 解剖

國土泰孝 ${ }^{1 !}$ 、伊藤正裕 ${ }^{2}$ 、石村 健 ${ }^{\prime \prime}$ 、谷内田真一"

岡野圭一1、、森 誠治"、唐沢幸彦",、岡田節雄"”、

若林久男"、前場隆志"、前田肇"

保存前の腸管内腔を洗浄がグラフトに与える影響を検討 した（対象に方法）ラット小腸を、冷乳酸加リンゲル 液(LR)でSMAより灌流し、保存しない(control群)，腸管 内腔洗浄在行わず12時間冷 $L R\left(4^{\circ} \mathrm{C}\right)$ に保存( 1 群), 腸管内 腔洗浄を行い保存(2群)の3群に分けた、グラフトviability は粘膜のtransmural potential difference(PD)、electric resistance $(R)$ 、組織学的障害(光学顕微鏡, 電子顕微鏡) ポトーシスの発生で評価した。(結果) 粘膜のPDは、 12時間保存後2群のPDは1群のPDに比べ有意に低かった $(p<0.05)$ Ｒは1,2群間に有意の差はなかった。病理組織 学的には保存後の時点ですでに1群の浮腫、壊死は強い 傾向にあったＳEMでは1,2群で絨毛上皮の脱落を認め た，TEMでは保存後細胞質内に著明な浮腫を、絨毛とク リプトに核の濃縮などアポトーシスを認めた。TUNEL 法でも同様にアポトーシスを認めた。（まとめ）腸管内 腔の洗浄によりグラフトviabilityは良好に保たれた。組 織学的には絨毛の破壊は、腸管内腔の洗浄により軽減さ れていたが、アポトーシスはクリプトでも観察された。
357

小䓪虚业・再灌流障害における好中球の

関与、および好中球エラスターゼ阻害剂の効果に関す る実験的検討

名古屋市立大学第二外科

加藤丈博、桑原義之、佐藤篤司、木村昌弘、

成田 清、正岡 昭

【目的】好中球数の増減が小腸虚血再灌流障害にど の様な影響を及ぼすか、また好中球エラスターゼ阻害 剂の効果をエネルギー代謝の変動、組織より検討した。 【方法】ラットを用い上腸間膜動脈を 30 分間閉塞した 後、150分再灌流した。I 群 : 対照群、II 群: 好中球增 加群 (G.CSF腹腔内注入)、群：好中球減少群

(cyclophosphamide腹腔内注入)、IV群：好中球エラ スターゼ阻害剤投与群（ono-5046再灌時静注）の4群に 分け、 ${ }^{3}{ }^{1} \mathrm{P}-\mathrm{MRS}$ 法にて $\beta$-ATP、Pi、PHを経時的に測定し た。また、H. E染色にて組織を検討した。【成績】(1)好

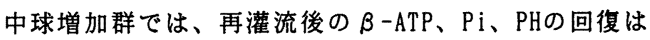
不良であった。(2)好中球減少群、好中球エラスターゼ 阻害剂投与群では、再灌流後の $\beta-A T P の$ 回復は良好で あった。【結論】好中球增加群でその障害が増悪し、 好中球減少群でその障害が抑制されたことから、好中 球が小腸虚血再灌流障害において重要な增悪因子とし て作用している可能性が示唆され、好中球エラスター ゼ阻害剤の投与によりその障害は軽減した。

358

ラット小腸移植モデルにおけるTyrosine

Kinase Inhibitor(Genistein)の免疫抑制効果の检討 金沢大学第 2 外科

高村博之,八木雅夫, 長谷部揵, 大西一朗, 山本精一, 谷卓, 橋本哲夫, 清水康一, 宮崎逸夫

ラット異系小腸移植モテルを用いてtyrosine kinas eの特異的阻害剤である genisteinの免疫抑制奻果に対 する検討を行ったので報告する。雄性BNからLENラット 人小腸を移植し、非治潦群 $(n=8)$ とgenistein投与群 $(n$ $=13) の 2$ 群を設定した。Genisteinは術後第0病日から第 7 病日 $(6 \mathrm{mg} / \mathrm{body})$ まで腹腔内投与した。非治举群は全例 7日以内に移植片が拒絶されたのに対し、genistein投 与群は全例12日間拒絶されなかった。細胞性免疫能を 評価するため、 ${ }^{5}{ }^{1} \mathrm{Cr}$ release assayを行ったところ、 genistein投与群の細胞障害活性は非治㩧群に比へて有 意に低かった。リンパ球混合培䖭 48 時間後の培食上清 中のIL-2蛋白濃度をELISA法を用いて测定したところ、 genistein投与群は非治療群に比へてて有意に低かった。 またリンパ球混合培養 48 時間後の培卷細胞および移植 7日目のgraft小腸のIL-2及びIL-2recepormRNA発現量 を検討したところ、genistein投与群のほうか非治療群 に比へて明らかに低かった。以上より、genisteinの免 疫抑制効果をin vivo実験系を用いて明らかにすること ができたものと考える。 
359 小腸移植後早期の寞容誘導を目的とした ドナ一脾リンパ球門脈内移入の有効性の検討 徳島大学第 1 外科 宮内隆行、石川正志、田代征記 目的：ラット異所性小腸移植(SBTX)において、トナ一 脾リンバ球の術中門脈内移入(DSPV)による小腸移植後 早期の宽容成立の可能性及びFK506の寞容誘導における 有効性を検討した。方法：ドナ一にBNラット $\left(\mathrm{RT}^{\mathrm{n}}{ }^{\mathrm{n}}\right)$ 、 レシヒエントにLewisラット(RT1')を用い、カフ法にて 異所性小腸移植を行い、以下の 4 群(各群 6 例)を作成し た。A 群；無処早、B 群；DSPV $\left(1 \times 10^{8}\right) 、 C$ 群 ; FK506 $\left(0.5 \mathrm{mg} / \mathrm{kg}\right.$ 、術後 $0 \sim 3$ 日), D群; $\operatorname{DSPV}\left(1 \times 10^{8}\right)$ 及び FK506(0.5 mg $/ \mathrm{kg}$ 、術後 $0 \sim 3$ 日)併用。以上 4 群におい て生存日数、拒絶発現、GVHD発現を锤察した。また C 群、D 群(各群 5 例)について、術後 7 日目にHE染色 による移植グラフトの組学的倹討、レシピエント脾 リンバ球の混合培養試験(MLR)を施行した。結果：A群 は全例が急性拒絶反応により術後 6 日以内に死亡した。 B 群は 4 例が重篤なGVHDにより3日で死亡し、2 例 が急性拒絶により6、13日目に死亡した。C 群は平 均6日で全例に拒絶が㑇められ、3例が14日以内に死 亡した。D群は 1 例が20日目に拒絶で死亡したが、5 例は100日以上生存し、拒絶発現は平均11日に延長され た。術後 7 日目のグラフト組䋘学的所見は、D群はC 群に比べ拒絶進行は抑制され、ドナ一抗原に対す MLR 活性は、D群において有意に抑制された。結語：DSPV とFK506短期投与の併用により拒絶発現の延長が確珰さ れ移植後早期の寛容誘導における有効性が示咬された。

360 ブ多小腸移植における急性拒絶反応の病理 組織学的検討-粘膜生検の意義と経時的変化について鹿児島大学第二外科、同第一病理*

西田聖剛、菰方輝夫、緒方誠司、松元二久、牛島 孝、 浜田信男、生駒 明、田中紘輝、平 明、吉田浩己* [目的］ブタにおける小腸移植の急性拒絶反応の検討 はほとんどない。今回ブタ全小腸allograftを同所性に 移植し、免疫抑制剂投与時、非投与時の急性拒絶反応 出現を経時的に粘膜生検し病理組織学的に検討した。

[対象と方法] I 群:FK506非投与群 $(n=7) 、 I I$ 群:FK506 投与群 $(n=4)$ 、自家移植例 $(n=1)$ を検討した。術後3日目 より14日目又は死亡時まで連日、Thiry-Vella loopよ り粘膜生検をした。移植時、剖検時に小腸全首標本を 採取した。病理所見をscore化し急性拒絶反応を、no change、mild、moderate、severe の4段階に分類した。 [結果] 平均生存日数は I 群10.8土5.84日、II群 41.2 土22.9日で有意差 $(\mathrm{p}<0.01)$ を認めた。粘膜生検像は I 群では術後3日よりmild rejectionが出現し始め、 moderate より比較的急速にsevere rejectionとなり 死亡し、経時的変化が強かった。II群ではno change からmild rejection像にとどまった。

[結語] 拒絶反応の主な病変は粘膜に認められ、粘膜 生検は急性拒絶反応の評価の指標として有用であった。 免疫抑制剂非投与時には経時的変化を強く認めた。
361

\section{原発性小腸平滑筋肉腫の 5 例}

\author{
岡山赤十字病院外科 ${ }^{1)}$ 、同病理 ${ }^{2}$ \\ 小野監作 ${ }^{1)}$ 、大塚康吉、川上俊爾、古谷四郎 \\ 辻 尚志、森山重治、山田真人、内藤 稔, \\ 池田英二、小西寿一郎、湯浅一郎、国友忠義 ${ }^{2)}$
}

最近 6 年間に空・回腸平滑筋肉腫の 5 例を経験した。 症例 $1: 65$ 才早、腫瘤触知で来院。CTにて卵巣癌疑い 開腹、Bauhin 弁より $50 \mathrm{~cm}$ の回腸に管外型腫溜あり、 回腸切除す。術後 6 年健康である。症例 $2: 51$ 才於、下 血で来院、腫瘤触知し、CTにて空腸悪性腫瘍リンパ節 転移疑い開腹、Treitz靯帯より $150 \mathrm{~cm}$ の空腸に管内型 腫瘤あり、空腸切除す。術後 10 カ月肝癌で死亡した。 症例 $3: 70$ 才市、下腹部不快感で婦人科を受診、USG、 MRIにて卵巣癌疑い開腹、Bauhin 弁より $220 \mathrm{~cm}$ の回 腸に管外型腫瘤あり、回腸切除す。術後 2 年 7 力月健康 である。症例 $4: 50 才 \hat{~} 、$ 黒色便で来院、小腸造影、CT、 血管造影にて空腸平滑筋腫疑い開腹、Treitz 鞋帯より $20 \mathrm{~cm}$ の空腸に管内外型腫瘤あり、空腸切除す。術後 1 年 2 力月健康である。症例 $5: 72$ 才。、腫瘤触知で来院、 CT、血管造影、生検にて平滑筋肉腫疑い開腹、Bauhin 弁より $170 \mathrm{~cm}$ の回腸に管外型腫瘤あり、直腸膀胱に浸 潤し、直腸膀胱部分切除を伴う回腸切除す。術後 11 力 月健康である。

362

福井医科大学第一外科

太田信次 長谷川保弘 関健一郎 前原正典

土山智邦 小林泰三 新本修一 片山寛次

広瀬和郎 山口明夫 中川原儀三

過去11年間に当科で手術治療を行ったファーター乳 頭部領域を除く十二指腸, 空腸, 回腸原発の小腸腫瘍 12 症例を検討した。12例の内訳は十二指腸では悪性リンパ 腫2例、腺癌2例、平滑筋腫 1 例、空腸では平滑筋腫、神 経鞘腫、過誤腫がそれぞれ1例、回腸は悪性リンパ腫3例 であった。主訴は腹痛が5例、下血及び分血が3例、腹 部腫瘤、嘔吐がそれぞれ1例であった。術前診断は小腸 腫瘍が 8 例で、卵巣腫瘍、膵癌がそれぞれ1例、他疾患 の手術中偶然発見されたものが2例であった。術中所見 では、空腸腫瘍は4例中 3 例がトライツ勒帯より $30 \mathrm{~cm}$ 以 内に、また回腸腫瘍は全例回腸末端部より $50 \mathrm{~cm}$ 以内に 存在した。術式は小腸部分切除が5例に、膵頭十二指 腸切除術が3例に、回盲部切除術が2例に施行された。 悪性腫瘍の予後は不良で 3 例が 1 年以内に死亡した。小 腸腫瘍は症状が多彩で術前診断に苦虑することが多いと されている。今回の症例の中にも5年間原因不明の貧血 として輸血を繰り返されてきたものや、初発症状から数 年経過しているものがあり、消化管の精査の際、常に小 腸腫瘍とその好発部位を念頭に置くべきと考えられた。 
363

千菜県がんセンター消化器外科1, 同血液化学療法科2

里見大介 ${ }^{1}$ 、渡辺 敏 1 、藤田昌宏 1 、渡辺一男 1

本田一郎1、山本 宏1、山田 滋1、神宫和彦 1

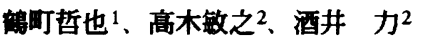

(はじめに）小腸悪性リンバ腫はまれな疾患で、今 回我々は11例を経臨したので報告する。（対象）過去 22年間（1973-1994）に当セン夕ーにて报った悪性リン ハ腫症例の総数は503例で、このうち小晹原発の11例に ついて臨床病理学的に湌討した。(結果) 年柃は18才 から64才で、女性 4 例、男性 7 例であった。原発部位 は、空腸 3 例、回腸末端部 8 例であった。碓定診断へ の経繶は、内視鏡などで術前診断が得られたのは 2 例 のみで、他は腸重積、イレウス、穿孔などの緊急手術 や他疾患の手術に際し発見された。組絊型は、びまん 大細胞型が 6 例と半数以上を占め、また、免疫組縓学 的に T細胞型が 2 例でいずれも空腸原発例であった。 病巣数では、空腸原発例が多発の煩向があったのに对 し、回腸原発は7 例が単発であった。根治度では、根 治度 $\mathrm{A}$ が 4 例、根治度 Cが 7 例で、1 例を除き術後化 癔を行い 8 例のC R を得、うち 4 例が無再発生存中で ある。(まとめ)小腸悪性リンパ腫は、救急病態下て の発見例が多かった。また、組絊学的性格や化療への 反応性の差異が予後を大きく左右すると考えられた。

364 鑑別診断

凝固線溶系からみた複雑性イレウスの早期

神戸大学医学部第一外科

矢野雅文、長畑洋司、安積靖友、沼田典久、和田哲 成、斎藤洋一

[目的] 単純性イレウスと複雑性イレウスとの治療法 は大きな相違があり早期の鑑別診断が重要である。そ こで血液凝固線溶系因子に着目して複誰性イレウスの 早期鑑別診断における意義を検討した。

[方法] 体重約3008のWistar系雄性ラットを用い、小 腸に内径 $3 \mathrm{~mm}$ のリングを装着し、単純性および複雓性 イレウスモデル（単純群、複稚群）を作成し、凝固線 溶系因子の変動を経時的に測定した。

[結果] 単純群のAntithrombin而は処置後24時間目以 降有意に上昇したが、複雑群では42時間目以降に上昇 した。Thrombin-antithrombin-III complex(TAT).は18 30 時間目に単純群と比較し有意に高値を示した。複雑群 の) tissue- Plasminogen Activator(tPA)、Plasminogen Activator Inhibitor(PAI-1) は単純群と比較すると処圈 後18時間目に有意な高值を示した。

[結論] 複雑群のTAT、tPA，PAI-1は単純群と比較し てイレウス作成後早期に有意な上昇を琹め、イレウス の早期爁別診断に対する有用性が示唆された。
365 当科における痗着イレウス症例の檢討

済生会滋贺紧病院外科

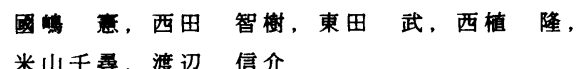

[目的］痹着性イレウスでは、保存的治瘦の限界を判 断し、手術適応を検討する必要がある。当科で経睮し た撚着性イレウスに対する治療法について検討した。

[対象と方法] 1990年から1994年までに当科で経䀫し た着性イレウス 83 例を対象とした。内訳は、手術療 法を行なつた群 $(=\mathrm{A}$ 洋) 18 例 、保存的治療のみで隇圧于

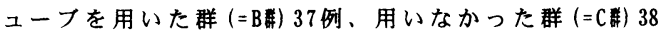
例であった。これらについて、入院時白血球数、宽解 までの期間、チューブ留置期間等について検討した。

[結果] 1. 背景因子には各群に有意差を認めなかった が、悪性腫病手術に多い傾向にあった。2. 入院時白血 球数は、A・B群がC群より高かった。3. 保存的治療では 多くの症例は2.29 2.41 日で改善を認め、手術の夕イ

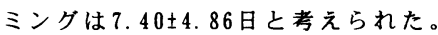

[結語] 術後要着性イレウスの治療は、原則的に保存 的に行なわれるが、各種所見に留意し、特に2日でチ ユーフの使用を、1週間で改善しない症例に対しては、 手術を検討する必要があると考えられた。

366

法 (OHP) の効果

開腹術後イレウスに対する高気圧酸素治療

高山赤十字病院外科

二村 学、横尾直樹、北角泰人、山口哲也、

白子隆志、米山哲司、森 茂、東 久弥、

米沢 圭、清水謙司

(目的) 開腹術後イレウスの1治療法として0HPの有用性 と限界を明らかにする。(対象と方法) 1993年6月～ 1995年8月に0HPを施行した開腹術後イレウス44例 (OHP 群：瘉着性25例、麻痺性19例)を、1992年1月～1993年 12 月の $0 H P を$ 施行せず保存的治療を行った開腹術後イ レウス 74 例 (非0HP群：癒着性59例、麻㾇性15例) と、 比較検討した。(結果)イレウス解除率は、0HP群癒着 性 $84.0 \%$ 、非OHP群瘾着性 $57.6 \%$ と $0 \mathrm{HP}$ 群が有意に高か った。6力月、 1 年再発率は、癒着性で $0 H P$ 群の方が低 率であった。OHP群の全回数、経口開始までの回数、 開始から経口開始までの日数は癒着性が有意に少なか った。無効例はOHPを3回以上施行して改善のない瘉着 性の 4 例で、血行障害や強固な瘉着を伴っていた。(結 論) $0 \mathrm{HP}$ は解除率から見て開腹術後イレウスの保存的治

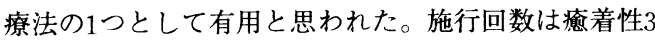
回、麻痺性7回程度を目安に、絞扼性イレウスが疑わ れる場合は速やかに再手術に移行するべきである。 
367

成人腸重積症例の検討

金沢医科大学一般 - 消化器外科

仁丹利行、篠原克浩、黒阪慶幸、松下昌弘、秋山高儀、

富田富士夫、斉藤人志、小坂健夫、喜多一郎、高島茂樹

【目的】成人腸重積症は、全腸重積症の $5 \sim 10 \%$ にす ぎず、器質的疾患に起因するものが多い。我々は、過 去 11 年間に当科で経験した成人腸重積症 11 例につい て検討を加えた。

【結果】内訳は、特発性腸重積症 2 例、悪性腫瘍 6 例 （癌 5 例、悪性リンパ腫 1 例）、良性腫瘍 3 例（偽粘 液腫、脂肪腫、Peutz-Jeghers 症候群(過誤腫)が各々 1 例）であった。年齢は 25 歳から 76 歳、平均年齢は 53.5 歳で、性別では男性 5 例、女性 6 例と差を認めなかっ た。発生部位別には、小腸一小腸型 2 例、回盲部型 4 例、大腸一大腸型 5 例であった。術前の臨床症状では、 11 例中 9 例が腹痛、嘔気、嘔吐等の腸閉塞症状を示し、 悪性腫瘍では 6 例すべてが臨床症状を有していた。11 例中 6 例が術前に診断可能であった。術前診断法とし ては、超音波検查、CT 検查が有用であった。腫瘍の 大きさは、有症状例では無症状例に比べて大きく、悪 性腫瘍では良性腫瘍に比べて大きかった。治療は、自 然寛解した 1 例を除き、先進部腫場を含む重積腸管切 除、もしくは術中ポリペクトミーを行い、術後経過は 全例良好であった。

368 末期癌イレウス治療に㧍ける経皮内視鏡 的胃痤造設を応用した減圧術（Decompression PEG） の有用性について

富士市立中央病院外科, 東京慈恵会医科大学第二外科* 鈴木 裕, 羽生信義, 成瀬 勝, 大平洋一, 恩田啓二, 鳥海弥寿雄, 中里雄一, 中山一彦, 佐藤慶一, 富田春郎, 山本 尚, 柏木秀幸*, 青木照明*

手術適応のない痁性腹膜炎イレゥス患者に対して, Percutane ous endos copi c gastrostomy（PEG）を応 用した減圧術を施行し良好な成績を得たので，末期癌 イレウス治療における本法の有用性について報告する. [対象および方法] 手術適応のない㾙性腹膜炎イレウ 又患者19例を対象とした。一期的ボタン型胃謏である One-step Button (OSB) を用いてPEG施行後, Button より $16 \mathrm{Fr} \mathrm{N}-\mathrm{G}$ tubeを胃底部に留置した。本法の評価 は，重篤な合併症がなく，アンケート調査で患者と家 族が本治療を行なって良かったと解答した場合を効果 ありとし、他はすべて無効とした。さらに, 臨床症状 をスコアー化し、効果ありを著効と有効に類別した。

[結果〕著効は 12 例, 有効 4 例, 無効 3 例であった。

〔結語〕PEGを用いたイレウス治療は，患者の苦痛を 楥和し，さらに経口搨取を可能にするなど，末期癌イ レウス患者に対する“palliative therapy”として有 効であると考えられた。
369 開腹歴のない成人イレウス牙術症例の検討 鳥取県立中央病院外科

菅沼 弘, 谷口哲也, 澤田 隆, 清水哲, 河村良筧, 岸 清志

【目的】開腹䄳のない患者に発症するイレウスには 種々の原因があるが, 術前に破診を得るのは必ずしも 容易ではない．このような開腹歴のないイレウス症例 についてその原因, 診断及び治撩に関し検討した。

【対象】1976年1月から1995年8月までに当科で手術 が行われた成人イレゥス 300 例のうち開腹歴のない 64 例を刘象とした。【結果】原因疢患では大晹癌が最も 多く 24 例 $(38 \%)$ ，次いで種々の内，外へルニア掞 頓16例, 癒着あるいは索状物によるもの 10 例, 腸軸 捻転7例（S 状結腸 4 例，小腸 3 例）などであった。術 前にイレウスの原因を診断できたのは全体の $52 \% に$ 過ぎなかった，瘉着あるいは索状物が原因のイレウス では術前診断例はなく，10例中6例が絞抳性イレウス で，緊急手術が必要であった。術式では腸切除術が 32 例 $(50 \%)$ ，晹㩲造設のみが18例（28\%）と多か った、【結珸】開腹歴のないイレウスでは，大腸站， ヘルニア谈頓が多い（約60\%）が，術前に原因を明 らかにできない效㧪性イレウスも少なくなく、いたず らに保存的治療に固執せず，全身状態を考虑して開腹 術に移行しなければならない。

370 大腸癌イレウス例の臨床病理学的検討とそ の長期予後について

北九州市立八幡病院外科

木戸川秀生、伊藤重彦、三輪晋智、佐野 功、田中賢治、 羽田野和彦、山口慎也、田川 努、吉田一也、西田卓弘、 岡田代吉、新海清人、大江久分、辻野直之

【目的】イレウス症状を呈した大腸癌症例の臨床病理学 的特徵、長期予後について検討した。【対象および方法】 当院で経験した大腸癌症例は 327 例である。イレウス群 66 例 (20.2\%) を対象とし非イレウス群 261 例と臨床 病理学的因子、長期予後について比較検討した。【結果】 イレウス群は男 36 例、女 30 例。 80 才以上は $19.7 \%$ で 非イレウス群 $10.2 \%$ に比べ約 2 倍と高率。イレウス群は S 状結腸 33.3\%と高頻度にみられた。イレウス群は右側 結腸群に多かった。5 生率はイレウス群では右側結腸群 が不良。緊急手術の 5 生率は $30.5 \%$ で待期手術の $46 \%$ と比較して良い。根治度 A のイレウス群 43 例中 $77.8 \%$ に一期的手術が、22.1\%に二期的手術が行われたが両者 の予後に差はない。【結語】1. イレウス群は 66 例であ り性別、年齡には有意差を認めず。2.イレウス群は S 状 結腸が $33.3 \%$ 高頻度にみられたが、非イレウス群との 比較では右側結腸群が多くみられた。3.イレウス群の 5 生率は右側結腸群が予後不良で緊急手術之待期手術、一 期的手術と二期的手術との間の予後の差はなかった。 